\title{
A COMPARATIVE ANALYSIS OF THE NUTRIENT COMPOSITION AND DIGESTIBILITY OF CALIFORNIA PERENNIAL AND ANNUAL GRASSES AT FOUR STAGES OF GROWTH
}

\author{
A Thesis \\ presented to \\ the Faculty of California Polytechnic State University, \\ San Luis Obispo
}

\begin{abstract}
In Partial Fulfillment
of the Requirements for the Degree

Master of Science in Agriculture with Specialization in

Animal Science
\end{abstract}

by

Elaina Deanne Cromer

August 2017 
(C) 2017

Elaina Deanne Cromer

ALL RIGHTS RESERVED 


\section{COMMITTEE MEMBERSHIP}

TITLE: A Comparative Analysis of the Nutrient Composition and Digestibility of California Perennial and Annual Grasses at Four Stages of Growth

AUTHOR: $\quad$ Elaina Deanne Cromer

DATE SUBMITTED: August 2017

COMMITTEE CHAIR: Dr. Keela Trennepohl, Ph.D.

Assistant Professor of Animal Science, Cal Poly

COMMITTEE MEMBER: Dr. Marc Horney, Ph.D., CRM

Assistant Professor of Animal Science, Cal Poly

COMMITTEE MEMBER: Dr. Kasey DeAtley, Ph.D.

Assistant Professor of Agriculture, Chico State 


\begin{abstract}
A Comparative Analysis of the Nutrient Composition and Digestibility of California Perennial and Annual Grasses at Four Stages of Growth
\end{abstract}

\title{
Elaina Deanne Cromer
}

Beef products represent the fourth largest agricultural commodity in the state of California, valuing more than $\$ 3$ billion from 2013 to 2015 (CDFA, 2016) and procure 90\% of the income for the range livestock industry (FRAP, 2003). Forages found on California's coastal, desert, foothill, and mountain ranges are the basis of the state's beef cattle industry. Understanding their nutritional quality of these forages is important for their effective use (George et al., 2001a; Waterman et al., 2014). The objectives of this research were to investigate the nutritional characteristics, and in situ digestbilities in Angus beef cattle, of common California annual and perennial grasses: wild oats (Avena barbata and Avena fatua), soft chess (Bromus hordeaceous), filaree (Erodium botrys), Italian ryegrass (Lolium multiflorum), blue wildrye (Elymus glaucus), creeping wildrye (Leymus tritichoides), melic (Melica californica, Melica imperfecta, Melica torreyana), foothill needlegrass (Nasella lepida), purple needlegrass (Nasella pulchra). Nutritional composition as a percentage of dry matter (crude protein, CP; neutral detergent fiber, NDF; acid detergent fiber, ADF; and acid detergent lignin, ADL) and digestibilities were compared at four growth stages: late vegetative (LV), early reproductive (ER), late reproductive (LR), and dry (D). Plant samples were collected in San Luis Obispo County, CA. Crude protein concentrations decreased, and fiber concentrations increased, with maturity $(P \leq 0.05)$. Perennial grasses contained more NDF and ADF than annual grasses, across all growth stages $(P \leq 0.05)$. Annual grasses were significantly higher than perennials in dry matter digestibility (\%DMD) at the $48 \mathrm{~h}$ incubation, when averaged across all growth stages ( $P \leq$ $0.05)$; and at the LR and D stages, when averaged across all incubation periods $(P \leq 0.05)$. Within the annual grasses, \%DMD was similar between ER, LR, and D stages. Within the perennial grasses, \%DMD was similar between the LR and D stages $(P \leq 0.05)$.

Keywords: ADF, annual, beef cattle, CP, dry matter digestibility, growth stage, in situ, NDF, organic matter digestibility, perennial 


\section{ACKNOWLEDGMENTS}

I will start with my sincere gratitude for the funding of this project, and the individuals, Dr. Keela Trennepohl, Dr. Marc Horney, and Dr. Kasey De'Atley, who applied for the USDA 15-079 Grant via Chico State University, which has made my education and research possible. Most importantly, I want to acknowledge my parents, Andy and Anna Cromer, who have had to suffer through being thousands of miles away from me while hearing about my ups and downs. I thank them for their encouragement and unconditional love.

In terms of working through the technicalities of completing each and every small puzzle piece of the larger project I owe my sincerest gratitude to Peter Walburger, who took time away from his work on the grounds at Camp San Luis to lead me and other students to locations of the study plant species on the military base. Several members of the biology department - Michael Curto, Dr. Jenn Yost, and Dr. David Keele, have helped me develop my knowledge of plant identification into a considerable working knowledge of botany and plant taxonomy. Special thanks to Aaron Lazanoff for being an invaluable resource and taking moments away from the ever-increasing demands on his schedule to tour me around the Escuela Ranch. I was able to familiarize myself with some important study plant species during these times.

There can never be enough stubborn roadblocks in the process of compiling the thesis. Determining the style guide for this bibliography was one of those roadblocks, and Katherine O'Clair was a great help in trudging through the muddy waters. I cannot give enough thanks to my lab buddies, Alexis Ulloa, Joshua Figg, Luis E. Alvarez, and Rhianne Maxwell for their assistance and support of one another's research projects as well as my own. Countless hours were spared by the help of Cal Poly Agriculture students and friends who helped me with my grass collections.

When it came time to run the in-situ trials at Chico, I was blown away by the amount of Chico students that were not only willing to help me, but were genuinely passionate about the project itself. These students showed up at the farm at 5 am to help remove bags from the cows and stayed until the washout procedures were complete. My sincere gratitude goes out to Kasey DeAtley, Animal Science professor at Chico State, for quickly recruiting students and ensuring that all materials needed were made available for the project.

I cannot begin to express the magnitude of a blessing that my lovely roommates Austin McLaggen, Sophie DeChristopher, Ellie O'Conner, and Lydia Anderson have been for me. They put up with my mood swings and were always there for me to cry to and hug. I will never forget the morning Lydia made me eggs and toast as I continued to slave away on an assignment I had been working on all night. All five of these ladies were the closest to family that I could have had during this whole endeavor. I am also immensely grateful for my spiritual mentor, Rachel Vallierre, for keeping me grounded in God's love and strength through times when I was most critical of myself. 


\section{TABLE OF CONTENTS}

PAGE

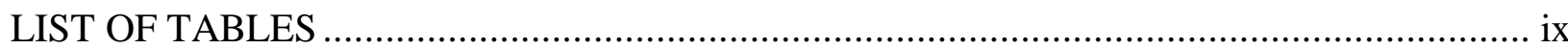

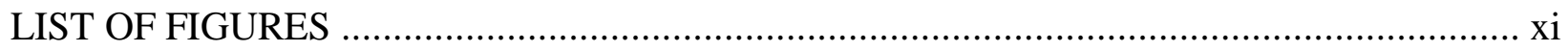

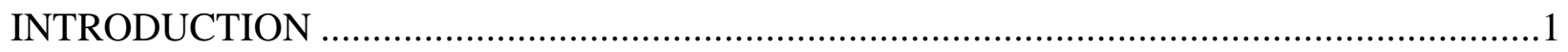

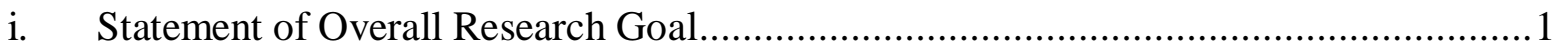

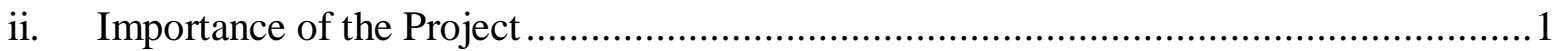

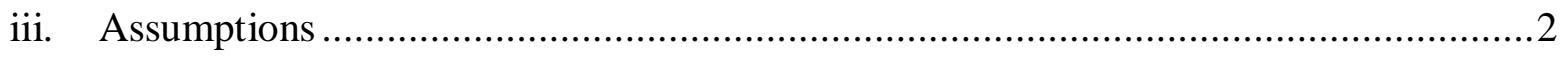

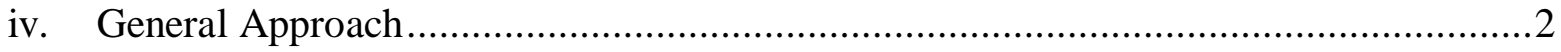

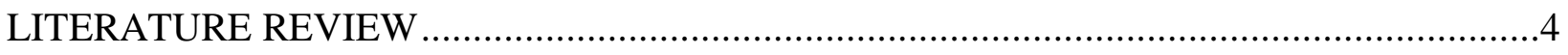

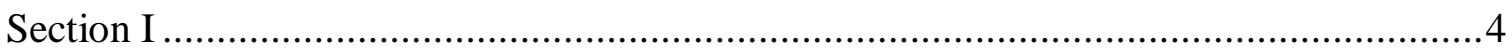

i. Historical and recent conversations on annual \& perennial grasses on the western

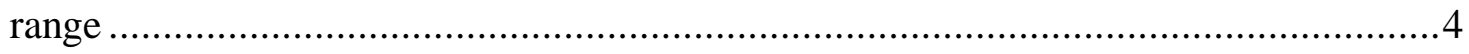

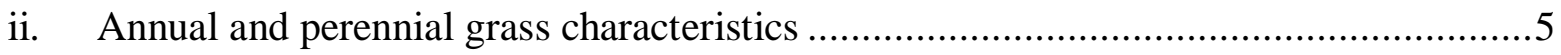

iii. Factors affecting variability in nutritive value of forages...........................................11

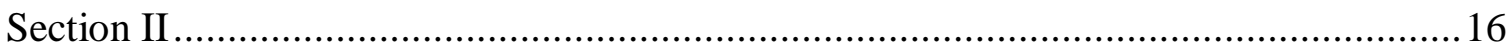

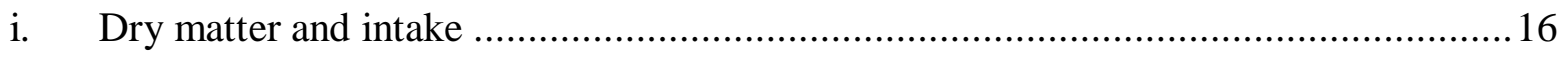

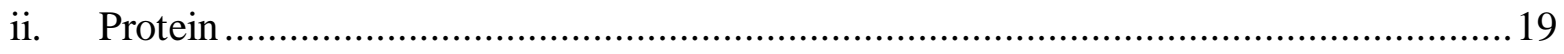

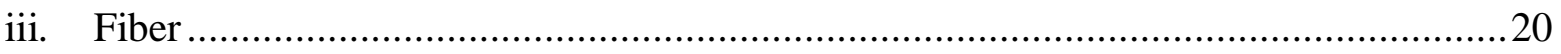

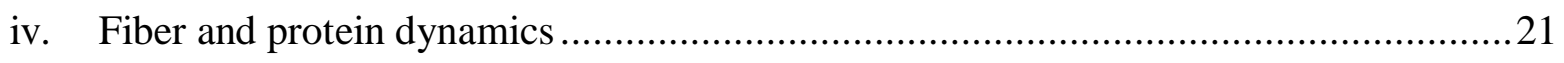

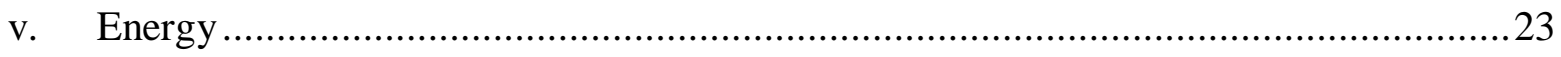

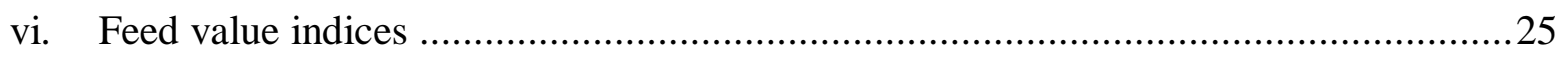

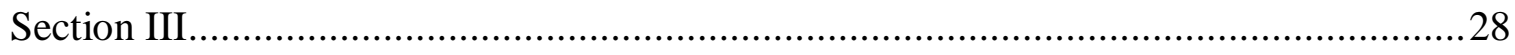


i. Animal behavior in regards to grazing selectivity and palatability .........................28

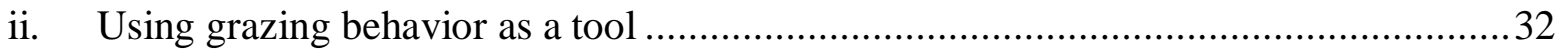

iii. Matching animal production with plant production ....................................... 33

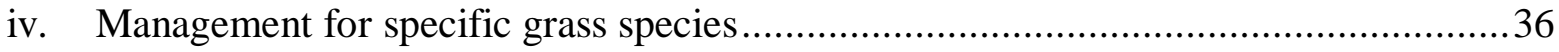

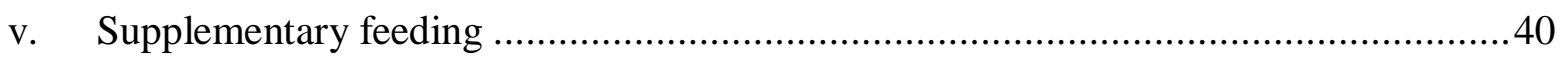

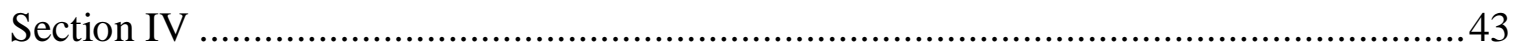

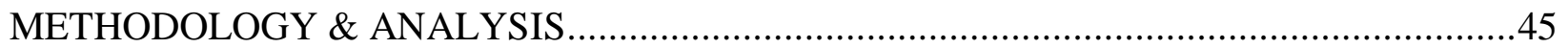

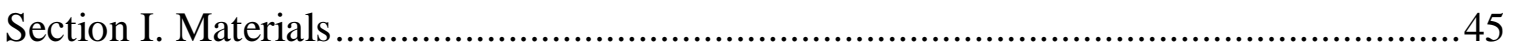

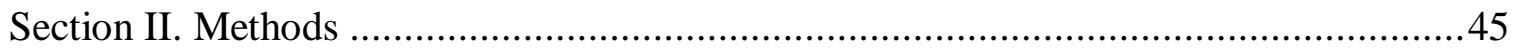

i. Plant Sample Collection............................................................................... 45

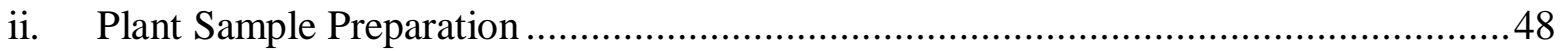

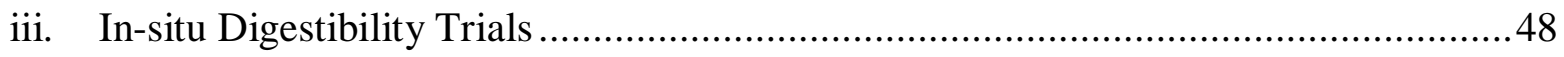

Section III. Chemical Composition ................................................................... 49

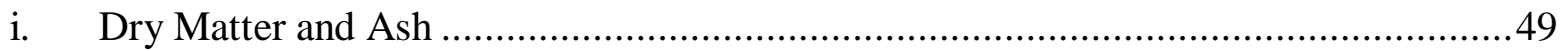

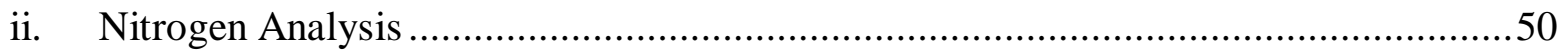

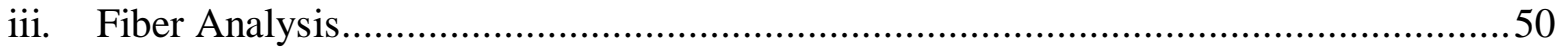

Section IV. Statistical Analysis ....................................................................... 51

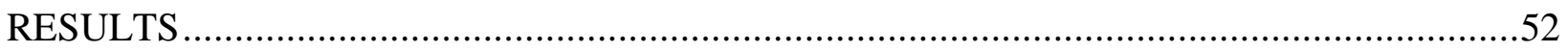

Section I. Information for plant species collected .........................................52

Section II. Annual and perennial grass chemical composition ..............................52

Section III. Chemical composition changes with grass maturity ...............................53

Section IV. Dry matter and organic matter digestibility of grasses ............................53

DISCUSSION 
Section I. Chemical composition of grasses and forbs at different growth stages.....

Section II. Growth stage and type significantly affect nutritive values of annual and

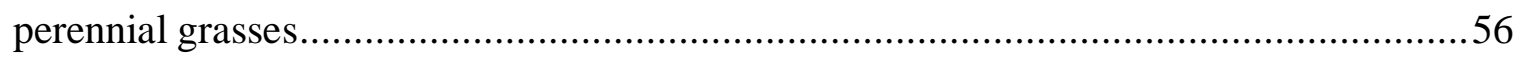

Section III. Effects of ruminal incubation period, growth stages, and growth type on

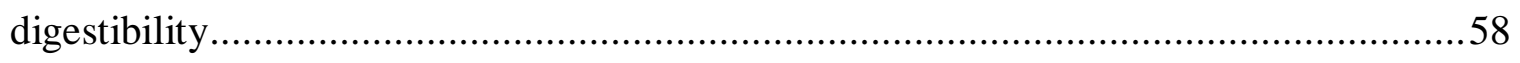

Section IV. Improving perennial digestibility ............................................ 61

Section V. Managing for differences between annual and perennial-dominated pastures 62

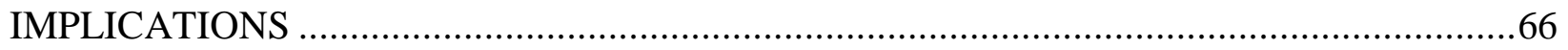

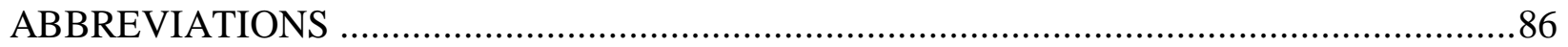

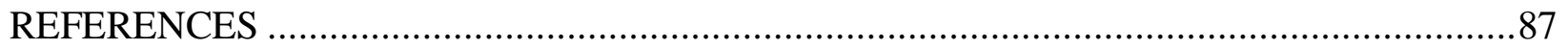

\section{APPENDICES}

Appendix A: Plant Collection Procedures ..................................................... 95

Appendix B: Plant Collection Site Maps ............................................................ 97

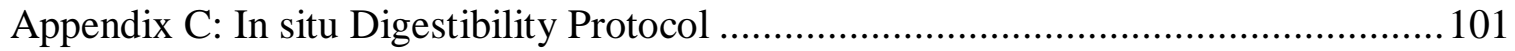

Appendix D: Dry Matter and Ashing Procedure............................................. 104

Appendix E: Example Fiber Analysis Datasheet ............................................ 108

Appendix F: Dry Matter, Organic Matter Datasheet........................................... 109

Appendix G: Nitrogen Data Example Sheet .................................................... 110

Appendix H: California Plant Species Report .....................................................113 


\section{LIST OF TABLES}

TABLE

PAGE

Table 1.1 Numerical stage of maturity associated with plant morphological characteristics

(George and Bell, 2001)

Table 1.2 Nutrient requirements (\%DM) across cattle and forage production stages, adapted

from the Beef NRC (2000) and Lalman (2001)..... 18

Table 2.1 Corresponding codes for grass and forbe species .68

Table 2.2 Protocol for determination of the four growth stages of grasses.

Table 2.3 Plant species collected at various sites in San Luis Obispo, California, from May

2016 to July 2016 and January 2017 to April 2017

Table 2.4 Months and year of collection, USDA species abbreviation (USDA-NRCS, 2017),

and growth stage of plant species were collected from San Luis Obispo, CA ..................71

Table 2.5 Chemical composition $(\% \mathrm{DM})$ of plant species sampled at late vegetative stage........72

Table 2.6 Chemical composition (\%DM) of plant species sampled at early reproductive stage ..73

Table 2.7 Chemical composition (\%DM) of plant species sampled at late reproductive stage ....75

Table 2.8 Chemical composition (\%DM) of plant species sampled at dry stage .77

Table 2.9 Descriptive means of nutritive values (\%DM) for grasses collected at all four stages

of growth ${ }^{2}$ .78

Table 2.10 Differences in means of nutritive values for all grasses grouped by growth type,

across four stages of growth ${ }^{1}$

Table 2.11 Differences in means of nutritive values of all grasses grouped by stage of growth,

across annual and perennial grasses 
Table 2.12 Dry matter digestibility (\%DMD) and organic matter digestibility (\%OMD) differences within annual and perennial grass species, after three in situ ruminal incubation periods $(\mathrm{h})$.

Table 2.13 Dry matter digestibility (\%DMD) and organic matter digestibility (\%OMD) differences between grass growth types after three in situ ruminal incubation periods (h) ..83

Table 2.14 Differences in \%DMD between annual and perennial grasses at four growth stages .84 Table 2.15 Differences in dry matter digestibility (\%DMD) between each growth stage across annuals and across perennials 


\section{LIST OF FIGURES}

FIGURE

PAGE

Figure 1.1. Percentage of plant composed of protein, fiber and lignin, and minerals in regards to four commonly depicted growth stages of plants, from least mature (leafy) to fully mature (bloom) (White and Wolf, 2009)

Figure 1.2. Representation of hierarchical order of selection by cattle with "Home Range" being the top order (adapted from Senft, 1989).

Figure 1.3. Seasonal forage qualities and quantities recorded from 1934 to 1947 at the San Joaquin Experimental Range (SJER) (George et al., 2001a).

Figure 1.4. Boxplots represent the percentage cover of perennial grasses in response to various levels of grazing compared to baseline. Nasella pulchra was not present in the continuously grazed plot (Bartolome, 2004). 


\section{INTRODUCTION}

\section{i. Statement of Overall Research Goal}

Forages found on California foothill ranges largely support the state's beef cattle industry (George et al., 2001). These lands are populated by several annual and perennial species of grasses and forbs. Waterman et al. (2014) argued in favor of the need for regionally specific nutrient composition data of forages, in accordance with seasonal dynamics. This information may provide ranchers and land managers with greater knowledge to aid management decisions for the maintenance and increased performance of their animals (Murray et al., 1978) in addition to enhancing rangeland health. Both goals are becoming a priority among the western ranching communities.

\section{ii. Importance of the Project}

Minimal information is known about the nutritional composition of California rangeland perennial and annual grass species at various stages of growth (phenologies; Ganskopp and Bohnert, 2001), and more specifically, their relative digestibilities as they relate to grazing beef cattle (Waterman et al., 2014). Further understanding of nutritional value and digestibility of common California plants may provide ranchers and land managers with the knowledge to make management decisions for the maintenance and increased performance of their animals (Murray et al., 1978). Throughout the year, livestock commonly graze annual grasslands, which make up the second largest land type (7.1\%) of the 45 native habitats in California (Davis et al., 1988). This provides a basis for the importance of understanding the seasonal dynamics of rangeland plants in order to 
monitor the timing of grazing, which has been identified as a pivotal aspect of enhancing rangeland health and promoting native grass restoration (Hennemen et al., 2014).

\section{iii. Assumptions}

- The two Angus cows were provided similar, forage-based diets in enough time to adapt the rumen to digest plant samples incubated for the experiment.

- The plant material which cattle select naturally is accurately represented by the individual sample types that were collected, dried, and ground.

- The variations in soil types within San Luis Obispo country, from which plant samples were collected, are less of a determining factor to plant nutrient content than the inherent genetics and growth stages of each species.

\section{iv. General Approach}

The study is based on applied and empirical research that analyzed the nutritional content and digestibility of nine common annual and perennial plant species in California according to the three hypotheses: (1) protein content and digestibility values will decrease and fiber content will increase as plants mature, (2) the average digestibility of annual plant species will be greater than the average digestibility of perennial plant species, and (3) mature perennials plant species will be less digestible, with higher fiber content, than mature annuals.

The research methods involved both field and laboratory analyses. Plant samples consisted of the nine species identified and collected in the field at four growth stages: late vegetative (LV), early reproductive (ER), late reproductive (LR), and dry (D). These samples were then taken to the lab for analysis of neutral detergent fiber (NDF), acid detergent fiber (ADF), acid detergent lignin (ADL), nitrogen $(\mathrm{N})$, dry matter (DM), and 
organic matter $(\mathrm{OM})$. All samples went through in situ digestibility trials, utilizing two Angus cows in which the samples were ruminally incubated for 12, 24, and 48 hours. The samples were removed at their respective time-point. Finally, dry matter digestibility (DMD) and organic matter digestibility (OMD) were calculated. All data was statistically analyzed and inferences were made inductively.

This study provides potential for an analytical study which would pose the question, "How does plant growth type (annual or perennial) affect nutritional composition and, in turn, digestibility?" A predictive study can be designed to model the impact that consumption of particular plant growth types has on Angus cattle performance. Theory application can be used with the findings of the current study to determine if Angus cattle gain weight on pastures that contain a majority of the plant species type which the finding suggest are most nutritious at each given season. 


\section{LITERATURE REVIEW}

\section{Section I}

\section{i. Historical and recent conversations on annual \& perennial grasses on the western range}

California is comprised of 101 million acres, 63 million are classified as rangeland (CDFF, 1988) and 11 million as grassland (Davis et al., 1998). The forages found on the California foothill ranges, largely support the state's range livestock industries (George et al., 2001a), of which $90 \%$ of the income is produced by beef cattle (FRAP, 2003). Both annual and perennial grasses can be found on lands utilized for grazing. According to the recent California Gap Analysis Project, annual grasslands are the second most common wildlife habitat type, accounting for $7.1 \%$ of the state or 28,921 $\mathrm{km}^{2}$ (Davis et al., 1998). Many of the nonnative annual plants were brought in by the Europeans (Corbin et al., 2007) and now cover over 10 million ha of grassland and oak savannah in California (Jackson, 1985; Heady, 1977). The high adaptability and suitability to the Mediterranean climate (Jackson, 1985) as well as the ability to survive under duress of continual grazing allowed these grasses to become well established in California. As a result, the prevalence of native annual and perennial grasses has lessened because they do better in less disturbed areas (HilleRisLambers et al., 2010).

Due to competition with introduced annual species (Barry et al., 2006), continued pressure from cattle grazing in the years 1850 to 1880 and throughout the 19th century, native perennial and annual grass species have been reported to compose less than $5 \%$ of the herbaceous cover found as sparse remnants in the California foothills (Bentley and 
Talbot, 1948; Jones and Love, 1945). Observations from field research conducted by Clements (1934) and Bentley and Talbot (1948) suggest that the majority of grasses native to California were perennial in growth form. Annuals were favored by California ranchers and stockmen through the mid-1900's (Bentley and Talbot, 1948; Hart, 1932) due to high production and palatability. However, perennial plants may serve as a potential standing forage in rangelands due to their extended growth period (Barry et al., 2006), which allows them to maintain vegetative tissue late into the summer and early in the fall. Therefore, increasing perennial species on rangeland may enable, livestock to graze later into the year; thus, needing less supplemental protein and energy (Wrysinski and Robins, 1998).

There is minimal information published about the quantity and quality of California rangeland perennial and annual grasses and forbs in regards to seasonal and environmental variation at various stages of growth (phenologies; Ganskopp and Bohnert, 2001; Waterman et al., 2014). Further understanding of the seasonal nutritional value and digestibility of common California grasses and forbs may provide ranchers and land managers with the knowledge to make management decisions for the maintenance and increased performance of their animals.

\section{ii. Annual and perennial grass characteristics}

Grasses consist largely of water, proteins, vitamins, minerals, soluble carbohydrates and insoluble carbohydrates (more commonly known as soluble and insoluble fiber; Pearson and Ison, 1997; Theander and Åman, 1979). Forbs, are morphologically different from to grasses and tend to be higher in protein and soluble 
fiber (Jung and Allen, 1995) as a result of nitrogen-fixing bacteria at the root-to-soil interface (Henzell and Ross, 1973). Comparatively, grasses are less digestible (Van Soest, 1994). Digestibility is determined primarily by the proportion of insoluble fiber to soluble fiber. On a cellular level, fiber is synonymous with carbohydrates that are comprised of various chain lengths and forms of polysaccharides and polymers (Baker et al., 1979). The molecular components that fall under the category of soluble fiber are: starches, pectins, gums, and mucilages (Baker et al., 1979; Fahey and Berger, 1988). Cellulose, hemicellulose, and lignin fall within the insoluble fiber category (Van Soest, 1994). The ratios of soluble and insoluble fiber vary with plant cell maturity, plant parts and structures, maturity of an individual plant, and species (Theander and Åman, 1979).

Upon maturity, the plant cell develops a secondary cell wall around the original primary structure. The function of the secondary cell wall is to provide structural support to the cell and, ultimately, to the plant. It is composed of at least $50 \%$ cellulose, some hemicellulose, and even less pectin, giving it increased rigidity and thickness in comparison with the primary cell wall, which is composed of pectin (Theander and Åman, 1979). Cellulose and hemicellulose are polysaccharide chains. They differ in types of subunits. The two types of polysaccharide chains are cross-linked together via diferulic bridges. Hemicellulose is also cross-linked to lignin. Lignin is a polymer formed from monolignols (Moore and Jung, 2001) and is integrated within and between the primary and secondary cell walls and acts as "glue" to encase plant cells, maintain structure, provide protection, and prevent water loss (Moore and Jung, 2001). Lignin begins to form once external structural components develop. Of the three components of insoluble fiber 
(i.e., cellulose, hemicellulose and lignin), lignin is the most limiting to digestibility primarily due to its complex structure.

The grass plant has three anatomical structures that are most commonly consumed by cattle: leaves, stems, and flowering parts (Arazani et al., 2004). The majority of cells found in the leaves are contained within a primary cell wall and serve as the photosynthesizing portion of the plant. The stems serve as the structural portion of the plant. They are composed of a large percentage of structural material (i.e., cellulose, hemicellulose, and lignin). The degree to which lignification will occur is determined by whether the plant stems are hollow or filled with pith (Van Soest, 1994). Perennial plants such as blue wildrye (Elymus glaucus) grow long hollow stems (field observation).

Depending on the level of maturity, the flowering parts can contain high levels of protein, fats, and vitamins in the germ/embryo; starch in the endosperm; and a high proportion insoluble fiber in the seed coat (Peterson and Soreng, 2007).

There are twelve standard stages of maturity (George and Bell), also generally termed as phenology, that define the development of grasses as well as forbs (Table 1.1).

Table 1.1. Numerical stage of maturity associated with plant morphological characteristics (George and Bell, 2001).

\begin{tabular}{cc}
\hline Stage number & Stage description \\
\hline 1 & Germinated \\
2 & Early vegetative \\
3 & Late vegetative \\
4 & Early bloom \\
5 & Mid bloom \\
6 & Full bloom \\
7 & Late bloom
\end{tabular}




$\begin{array}{cc}8 & \text { Milk stage } \\ 9 & \text { Dough stage } \\ 10 & \text { Mature } \\ 11 & \text { Dry }\end{array}$

$12 \quad$ Dry leached

Four of the most distinguishable stages have been depicted in Figure 1.1 by White and Wolf (2009). George and Bell (2001) have measured nutritional quality of annual forages relative to each of the twelve growth stages (Table 1.1). The general patterns detected are also demonstrated across the four growth stages (Figure 1.1). Throughout these growth stages, changes in proportions of various plant parts and forage nutritional values are dynamic. Upon initial lengthening of the internode, the plant is in the earliest, vegetative stage and the ratio of leaves to stems is high. The perennial, creeping wildrye (Leymus tritichoides), stays in the vegetative stage for a long period of time (Laca, 2015), (i.e., January to May; Wrysinski and Robins, 1998). Within the protective cover of the sheath, the apical meristem begins to develop a seed head. As the internode continues to lengthen, the developing seed head emerges from the sheath, revealing the characteristic "boot stage", indicating that the plant has reached early reproductive growth. On the seed head, each individual spikelet produces anthers that allow for pollination to occur, which then triggers the maturation of viable seeds and indicates late reproductive growth. As the plant goes through early reproductive and then late reproductive stages, the ratio of stems to leaves increases and cellulose, hemicellulose, and lignin become more prevalent due to increased formation of secondary cell walls (Figure 1.1). 


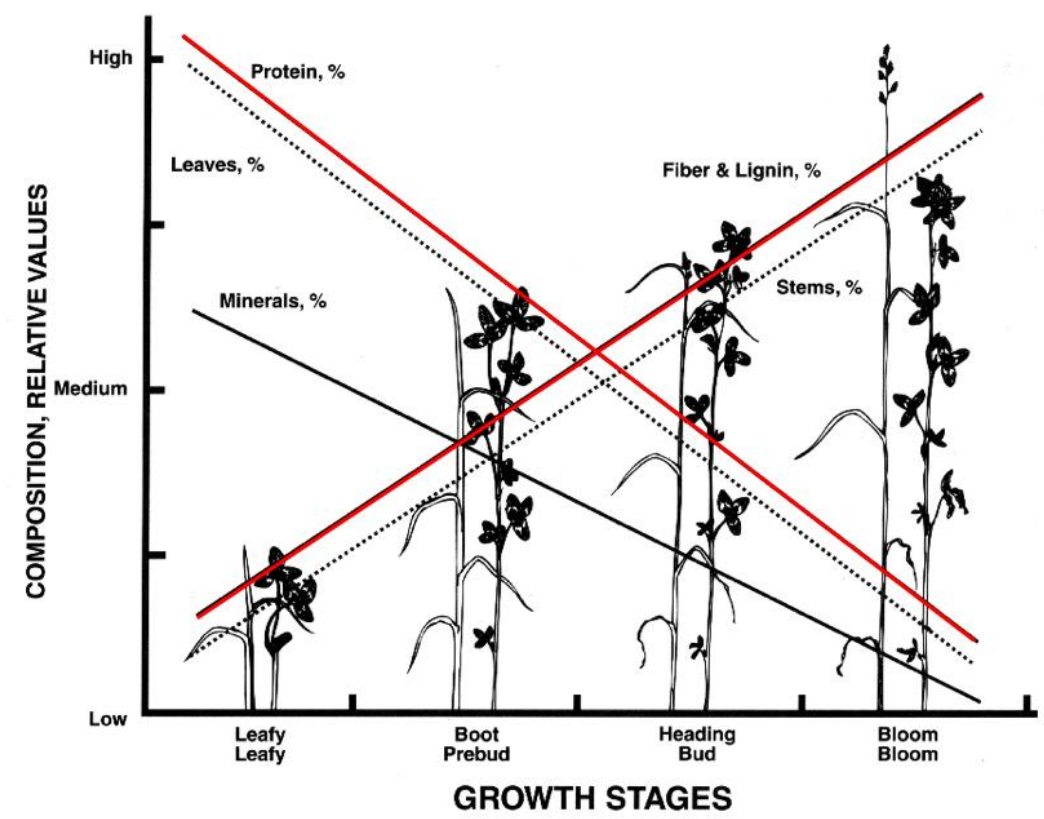

Figure 1.1. Percentage of plant composed of protein, fiber and lignin, and minerals in regards to four commonly depicted growth stages of plants, from least mature (leafy) to fully mature (bloom) (White and Wolf, 2009).

Cellulose specifically, is approximately 20 percent of the plant in the first stages of growth, $28 \%$ in the later reproductive stage, and $35-45 \%$ when the grass plant is dry (Fahey and Berger, 1988).

Ryegrass and fescue-based pastures in Victoria, Australia, showed that, in the winter months (early growth stages), NDF concentration was low, while CP, DMD, and ME were high. Adversely, in the summer months (late growth stages), NDF concentration increased while CP, DMD, and ME decreased (Thamaraj et al., 2008). In comparison, forbs maintain a higher amount of $\mathrm{CP}$ throughout the entirety of the plant and through all growth stages, especially due to the fact that leguminous plants utilize nitrogen-fixing bacteria (Henzell and Ross, 1973). 
Slight differences in forage nutritional dynamics between the annual and perennial grass types may exist due to the timing and inherent patterns of growth. Perennial species tend to have an extended growth season compared to annuals. In California, shoots of perennial species can begin to emerge as soon as late fall (Laude, 1953; Reever Morghan et al., 2007) and many plants may still be in late reproductive phase towards the end of June. When growth is complete, the plant goes dormant (Chiariello, 1989; Reever Morghan et al., 2007), maintaining living tissue within the bottom 3 to 6 inches of the tiller during the summer. When compared with congeneric (within the same genus) annuals, perennials demonstrated a higher allocation of biomass to the sheaths and roots, and a higher dry-weight to fresh-weight ratio.

Annual species in California develop much more rapidly (Garnier, 1992). Most of their resources go towards seed production and by mid-May all annual grass types have died and dropped their seeds (Chiariello, 1989). In comparison with congeneric perennials, annual species have also demonstrated greater leaf area, which is an indication of how much leaf dry matter is expanded (Garnier, 1992).

Sun et al. (2010) evaluated chemical composition and digestibility of several cultivars of congeneric annual and perennial ryegrass, Lolium spp., in New Zealand; The grass samples were collected in early and late winter growth stages. The ME for cultivars of annual ryegrass, averaged 12.7 MJ/kg in June and $13.0 \mathrm{MJ} / \mathrm{kg}$ in August. The patterns for ME mimic those found for NDF of both annual and perennial ryegrasses. Across both sampling periods (i.e., June and August), perennial ryegrass averaged $468 \mathrm{~g} / \mathrm{kg}$ for NDF and annual ryegrass averaged $414.5 \mathrm{~g} / \mathrm{kg}$, suggesting that the perennial cultivars would be less digestible. In sacco digestibility trials, revealed that effective degradability and 
soluble fractions were higher in annual ryegrass cultivars and the indigestible fraction was lower for annual ryegrass cultivars (Sun et al., 2010). Analysis of nonstructural carbohydrate content of 20-25 cm tall perennial ryegrass in Scotland resulted in a higher percentage of water-soluble carbohydrates than orchard or timothy grasses of different genera (as cited by Smith, 1973).

Digestibility characteristics of a forage may not always be the result of growth and maturity level. Changes in nutrient composition of standing forages through the seasons can be due to leaching of nutrients by rainwater, which can remove up to $30 \%$ of the phosphorous, $20 \%$ of the crude protein, and 35\% of the nitrogen-free extract (NFE), which consists of carbohydrates, starches, and hemicelluloses (Shepherd et al., 1954). In light of the various factors that affect digestibility, it is rare that forage digestibility values should exceed 70-74\% DM (Oklahoma Cooperative Extension, 2000).

\section{iii. Factors affecting variability in nutritive value of forages}

Knowledge of environmental factors is imperative from a range livestock standpoint because forage nutrient supply curves are highly dependent upon climate (Waterman et al., 2014). The patterns of change in nutritional quality (increases in fiber content and decreases in crude protein, water, and digestibility) upon maturity are similar from year to year because phenological development is regulated primarily by photoperiod. However, the slight variations observed in nutritional quality from year to year occur due to annual variations in temperature, evaporation, and water stress (Manske, 1999). There are four primary factors affecting forage productivity and species composition: precipitation, temperature, soil characteristics, and plant residue (George 
and Fulgham, 1989; George et al., 2001a). Of the factors listed, the two that influence nutritive value to the highest degree are air temperature and soil moisture (Huston and Pinchak, 1991). Inherent differences in warm-season and cool-season plants also affect nutritive value. Lastly, the nutrient composition of a plant can change dependent upon whether or not it has been grazed (Van Soest, 1994).

Dramatic increases in temperature, as seen from April to June in California, are followed by rapid plant growth and increased lignification. The Mediterranean climate produces lower temperatures from October to March, during which cool-season plants will begin to germinate and mature. With extended cooler seasons, plants may reach peak production later, but retain a higher nutrient concentration for longer (Van Soest, 1994; Huston and Pinchak, 1991). The timing of germination is highly influenced by soil temperature (which is affected by air temperature). Each plant species geminates provided that a specific temperature range is reached and patterns of temperature fluctuation are optimal (George and Rice, 2017). Rate of senescence, while primarily affected by level of photosynthetic activity, increases with higher temperatures and with water stress (Manske, 1999). Water restriction has a similar effect as that of lower temperatures upon plant growth by increasing rate of plant growth and lignification (Huston and Pinchak, 1991).

Just as the soil moisture affects absorption of nutrients and impacts the plant composition, so does the character of the soil medium (Gordon and Sampson, 1939). Varying soil types may have vastly different water-holding capacities. However, soil moisture is generally depleted by the end of spring growth in California (George and Fulgham, 1989). At this point, or when plants are mature, peak forage production has 
been met (George et al., 2001a). Perennial grasses often display root growth of $1 \mathrm{~m}$, or deeper, which allows for a longer period of growth compared to annuals, but also depletes soil water reserves (Peterson and Soreng, 2007). An exception would be the annual forb, Erodium botrys (broadleaf filaree), of which 30-35\% of the roots have been allocated to deeper than $50 \mathrm{~cm}$ in the soil profile. This may explain why this annual species can hold water late into the month of June (Peterson and Soreng, 2007). When annuals and perennials are grown together and compete for water resources, it has been shown that water in the top $60 \mathrm{~cm}$ of the soil was depleted, but water remained below 60 cm (Peterson and Soreng, 2007), therefore, pastures composed of a mixture of perennials and annuals may have an extended grazing season.

Where environment, plant physiology, and plant morphology coincide most evidently is through the differences in cool-season (C3) and warm-season (C4) plants. Both perennial and annual growth types can be $\mathrm{C} 3$ or $\mathrm{C} 4$ plants (National Forage and Grasslands Curriculum, 2016). Air and soil temperatures affect whether a C3 or C4 will occur in a given region or not (Waterman et al., 2014). The optimum air temperature range for the growth of $\mathrm{C} 3$ plants is $65-75^{\circ} \mathrm{F}$ and, for $\mathrm{C} 4$ plants, $90-95^{\circ} \mathrm{F}$. The optimum soil temperature range for $\mathrm{C} 3$ plants is $40-45^{\circ} \mathrm{F}$, and for $\mathrm{C} 4$ plants, $60-65^{\circ} \mathrm{F}$. As the temperature increases, $\mathrm{C} 3$ plants lose efficiency, whereas $\mathrm{C} 4$ plants become more efficient. Between 15\% and 40\% of light energy taken up by C3 plants is lost through photorespiration, and this is further exacerbated by increases in temperature (National Forage and Grassland Curriculum, 2016).

The nutritive value $\mathrm{C} 3$ and $\mathrm{C} 4$ plants will drastically differ due to respective differences in physiological processes. The $\mathrm{C} 4$ plant contains greater proportions of 
schlerenchyma, epidermis, and vascular tissue, contributing to its higher lignin content than that of the C3 plant (Huston and Pinchak, 1991). It also tends to have a low leaf to stem ratio, which further elevates its proportion of structural components. Cool season grasses contain a higher percentage of $\mathrm{CP}$, with $\mathrm{C} 3$ perennials containing slightly greater percentages of CP than C3 annuals (Huston and Pinchak, 1991). Some C4 plants have the potential of having a higher nutritive value if adapted to temperate, rather than tropical climates (Van Soest, 1994). The C3 grasses contain long-chain fructose polymers, as opposed to starch, which is found in greater quantities in legumes and C4 plants (Pearson and Ison, 1997). It has also been reported that C3 grasses have lesser concentrations of $\mathrm{NDF}$ and $\mathrm{ADF}$ than $\mathrm{C} 4$ grasses, leading to improved animal performance when fed cool season grasses (Phillips et al., 2009).

Grazing also has a noticeable effect on the nutritive value of grass plants. Upon initial defoliation, carbon and nitrogen levels decrease within the plant. Carbon utilized for regrowth in active shoot meristematic tissue is not drawn from carbon reserves in the roots, but from the current photosynthetic carbon in the leaves. Severe defoliation disables the plant from actively photosynthesizing, thereby drawing carbon for regrowth from the reserves required by dormant buds for first spring growth (Manske, 1999; Jackson and Bartolome, 2007). Over time, severe defoliation will inevitably reduce production (Briske and Heitschmidt, 1991). However, defoliated individuals have shown to have higher dark respiration rates than that of non-defoliated individuals at the same growth stage, denoting a higher protein content of the former (Atkinson, 1986). Dark respiration rates are analyzed to provide an estimate of plant protein content (Manske, 1999). Defoliated individuals have also demonstrated a lesser degree of lignification 
compared to non-defoliated counterparts (Van Soest, 1994). These observations provide evidence that managed defoliation can potentially improve the digestibility of grasses. 


\section{Section II}

A substantial amount of research has been done to determine the digestibility and degradation of various nutritional components from commonly cultivated forages. However, minimal experimentation has been done to determine the differences among digestibility and ruminal degradation of various native grasses, with inherently different growth types, and patterns (Waterman et al., 2014). To address this issue, it is important to first develop an understanding of the measurable components that are relevant to forage evaluation in consideration for ruminal digestion. The primary components are: dry matter (DM), dry matter digestibility (DMD), crude protein $(\mathrm{CP})$, crude fiber $(\mathrm{CF})$, acid detergent fiber (ADF), neutral detergent fiber (NDF), total digestible nutrients (TDN), metabolizable energy (ME), and net energy (NE). Of these components, energy and protein are the most limiting in California foothills; thus, of major concern to livestock producers (George et al., 2001b). This literature review will primarily focus on the needs of a $1300 \mathrm{lb}$ dry cow and a $700 \mathrm{lb}$ stocker, with occasional reference to high energy demands of the lactating cow, for comparison.

\section{i. Dry matter and intake}

As a standard, all feed and forage materials should be evaluated on a dry matter basis (DMB). When a majority of the water has been removed from the feed sample components are referred to on a DMB. The proportions of nutritional components and moisture content are variable across grass species; thus, comparing individual samples on a DMB is essential to determine the base nutrients the sample will provide to the grazing 
animal. Furthermore, the amount of dry feed consumed by a grazing animal is also variable, especially across seasons, and is determined as dry matter intake (DMI).

The National Research Council (2000) has provided several equations useful for predicting DMI with adjustments for various factors. These factors include: animal body weight (BW), level of performance (milk production, in the case of the lactating cow) at a given stage of production, energy content of the diet, and body condition score (Oklahoma Cooperative Extension, 2000). The adjustments include: breed, animal environment impacts, anabolic implant (a hormonal, growth-promoting implant), and temperature (NRC, 2000). Ruminal fermentation processes also limit the amount of DMI through pH and osmotic pressure (Van Soest, 1994). These factors aside, a cow, dry or lactating, will consume more DM from late vegetative forage, than that of early reproductive, late reproductive or dry forages due to the increased rate of digestion associated with higher quality forages (Table 1.2; NRC, 2000; Oklahoma Cooperative Extension, 2000). It has also been reported that the amount of NDF and ADF consumed by lambs and ewes in a day was related to DMI (Phillips et al., 2009). 


\section{Table 1.2}

Nutrient requirements (\%DM) across cattle and forage production stages, adapted from the Beef NRC (2000) and Lalman (2001).

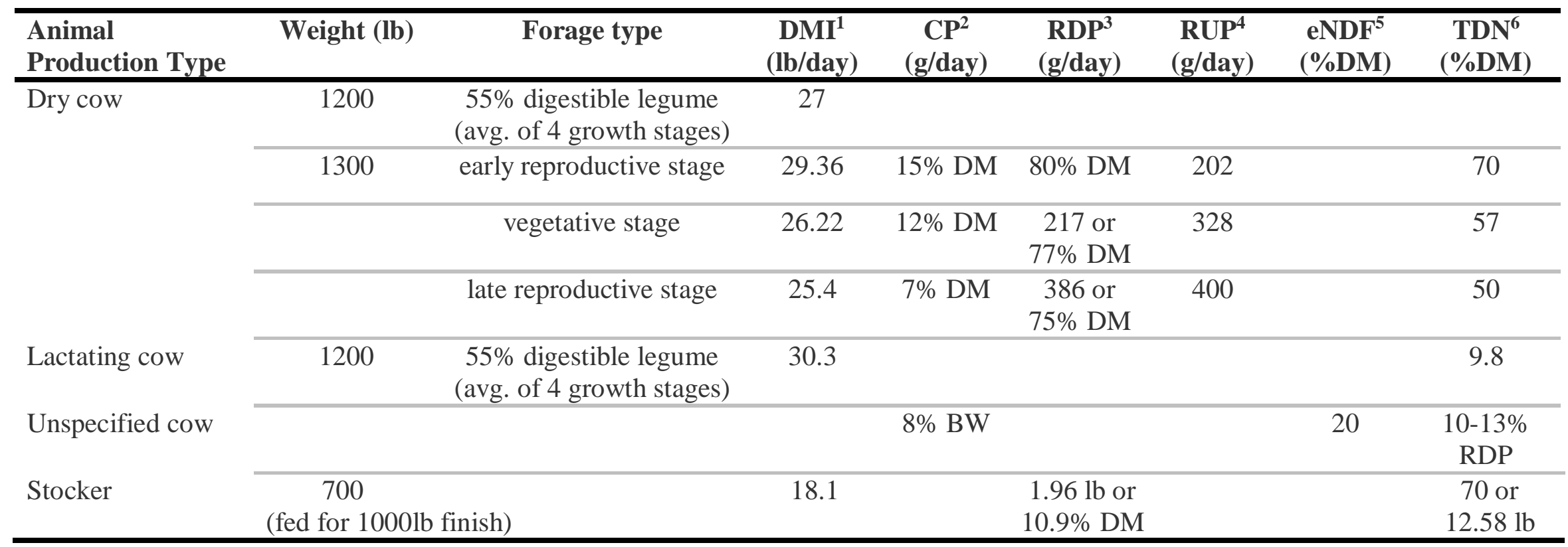

${ }^{1}$ dry matter intake

${ }^{2}$ crude protein

${ }^{3}$ rumen degradable protein

${ }^{4}$ rumen undegradable protein

${ }^{5}$ effective neutral detergent fiber

${ }^{6}$ total digestible nutrients (TDN) 


\section{ii. Protein}

The breakdown of material via microbial and enzymatic processes in a ruminant animal is often referred to as digestibility or degradation. It is important to understand that these terms have significantly different meanings. Degradation is the breakdown of a specific nutrient or plant part at a specific location along the digestive tract. Degradation is occurring constantly throughout the process of digestion by enzymes or microbes that degrade macromolecules (Leng, 1973). Digestibility is a more general term used to quantify the total degradation of macromolecules into simpler compounds via processes (mechanical, enzymatic, microbial, etc.) occurring along the entire digestive tract (Merchen, 1988). The more digestible that a feed is, the sooner the animal will intake enough feed to reach its energy requirement(s) (NRC, 2000).

The portion of dietary CP, 60-65\% that bypasses degradation by microorganisms in the rumen is referred to as rumen undegradable protein (RUP). Rumen degradable protein (RDP) is the portion of dietary $\mathrm{CP}(35-40 \%)$ that is available for degradation by rumen microorganisms (Jenkins, 2015; Waterman et al., 2014). The protein requirement of cattle is most often met by a combination of RUP and RDP (Pearson and Ison, 1997). This includes the nitrogen needs of the rumen microbes and the protein needs of the host animal (NRC, 1989). Ruminants fortunately have the ability to produce their own protein in the form of microbial crude protein (MCP), from the rumen microbiome when protein from forages is low (Owens and Zinn, 1988).

Seasonal variation in California can dramatically impact the $\mathrm{CP}$ content of forages, which also affects the digestibility. The surface area of proteins available to microbes, as well the chemical nature of proteins, are some factors that determine their 
degradability (NRC, 1989). Most protein in forages is either derived from cytoplasmic or chloroplastic proteins, nucleoprotein from the nucleus, and, in the case of plant cell wall tissue, extensins (Van Soest, 1994). Extensins are mostly found in higher concentration in the stems, serving as structural support by cross-linking cell wall fibers together. Comparatively, cytoplasmic, or chloroplastic proteins, will be found in higher concentrations in the leaves. Younger tissues in plants tend to contain a higher concentration of CP (Laca, 2015) and vegetative plant material contains highly soluble protein that can be more easily degraded by rumen bacterial proteases (Leng, 1973; Reid, 1962). Bohnert et al. (2011) have noted that cool season (C3) forages have a higher RDP in comparison with warm season (C4) forages, which have a lower RDP. In regards to DMI, the younger, cool season, and other forages of higher nutritional quality, are able to able to be consumed at a higher rate, and therefore in higher quantities, as opposed to the more mature forages, in which components such as lignin occlude the degradation of proteins (Oklahoma Cooperative Extension, 2000).

\section{iii. Fiber}

Crude fiber $(\mathrm{CF})$ is a less accurate measurement of the amount of structural carbohydrates in a feed. The more recent measurements, as developed by Van Soest (1994), are neutral detergent fiber (NDF) and acid detergent fiber (ADF). These measurements provide the breakdown of fiber types generally as a \%DM of a feed or forage. Neutral detergent fiber consists of the hemicellulose and some cellulose after the soluble starches and some keratins have been removed from the forage sample (Van Soest, 1994). Hemicellulose and cellulose contribute largely to the ruminal fill of an 
animal upon voluntary consumption. For this reason, NDF is commonly used as a predictor of DMI and is desired in low amounts (UNL, 2016; Mertens, 1983). Acid detergent fiber consists of the remaining cellulose in combination with lignin from forages, which are the least digestible components. Forages with low ADF concentration are desirable because they will be more digestible and therefore have a higher energy value (UNL, 2016; Mertens, 1983). Cellulolytic bacteria inhabiting the rumen produce various enzymes capable of degrading cellulose and hemicellulose (Leng, 1973). Lignification restricts degradation by all bacterial enzymes, but especially cellulase (Leng, 1973), due to highly interwoven matrices of chemical bonds formed between lignin and the plant structural polysaccharides (Bailey, 1973). Fiber is a component of the diet that needs to be monitored so that other nutritional components can be adjusted accordingly.

\section{iv. Fiber and protein dynamics}

The amount of forage that an animal should consume, or voluntarily consumes, is highly dependent upon the nutritional quality of the forage (Oklahoma Cooperative Extension, 2000). In addition, the two most important factors that affect fermentation of carbohydrates in the rumen are: the extent to which a plant has undergone lignification and, second, the availability of protein or non-protein nitrogen (NPN; Leng, 1973). Gordon and Sampson (1939) have clearly outlined the dynamics of CP and CF throughout life cycles of various plant species over the course of a three-year study. Most nutrient constituents tended to decline throughout the plant's life cycle, while $\mathrm{CF}$ increased (Gordon and Sampson, 1939). An issue with high-fiber and low-nitrogen 
forage is that it can lead to a protein deficiency, which, in turn, can lead to a decrease in feed intake. In this situation, supplementing nitrogen can increase DMI substantially (Galyean and Goetsch, 1993). A response in forage intake can be clearly observed if CP content of the forage is less than 6-8\% of the $\operatorname{diet}(\mathrm{NRC}, 1987)$.

Components of the diet can be increased or decreased dependent on the fiber content. Besides the values listed by the NRC for effective NDF (eNDF), approximaely $20 \% \mathrm{DM}$, there are no specific fiber requirements for the ruminant animal. Effective $\mathrm{NDF}$ takes into account the rumen microbial yield in response to the rumen $\mathrm{pH}$ and is the percentage of NDF deemed effective for "stimulating chewing and salivation, rumination, and rumen motility" (NRC, 2000). The NRC lists the nutrient requirements of gestating and lactating beef cows on diets from forages of varying maturities (Table 1.2). The diets containing less mature forages with low fiber content, allow the DMI to increase. The diets containing mature forages with high fiber content decrease the DMI and contain a smaller amount of RDP and RUP (NRC, 2000). Alternatively, there is a benefit to feeding forages of differing NDF contents. Mertens et al. (1983) found that cows fed a diet containing a 36\% total NDF content, but from various forage types, produced 20-25 kg milk per day. Reaching an optimal milk production depends upon the level of fiber intake and the body size of the animal. Larger ruminant animals can consume more fiber due to the sheer volume of their rumen (Van Soest, 1994). According to intake predictions, beef breeds should consume less DM than Holstein and Holstein-beef crosses, demonstrating that genetics affect intake capacity (NRC, 1987). 


\section{v. Energy}

Tolkamp and Ketelaars (1992) have theorized that feed intake behavior and regulation in ruminants is aimed at maximizing the net energy intake (NEI) per liter of oxygen consumed. Minimizing oxygen consumption would thereby reduce accumulation of damage to tissues and prolong life. When the quality of a feed rises, the efficiency of metabolism and NEI rise. Net energy (NE) is used to express the feed value as "the energy allocated to a product from the animal, in addition to the energy lost as heat" (Van Soest, 1994). Kellner (1912) noted that the fiber content of the diet has a particularly large effect on the increment of heat produced by the animal, which is defined as the difference between metabolizable energy (ME) and net energy (NE). The heat increment noticeably increases following ingestion and varies in proportion to surface area. The greater the heat increment, the more energy that is lost (as cited by Van Soest, 1994). This heat is produced via the oxidation of volatile fatty acids, lactic acid, carbon dioxide, methane, glucose, and amino acids - the products of ruminal digestion (Pearson \& Ison, 1997).

In the mid-1900's Moore et al. (1953) used the estimated net energy (ENE) system (developed by Frank Morrison) to compare the total digestible nutrient content (TDN) of corn compared to alfalfa, in relation to the ENE of both feeds as well. Their findings showed that one pound of TDN in corn had a greater NE than one pound of TDN in alfalfa. Alfalfa resulted in a higher heat increment due to its increased fiber content (Van Soest, 1994), thus a lower TDN.

Total digestible nutrients express the sum of feed components (digestible starch, fiber, protein, fat, ash, and minerals) relative to their energy content and accounting for 
high energy of fat (Oklahoma Cooperative Extension, 2000; Van Soest, 1994). When determining energy efficiency, it is important to provide a complete measure of the energy available to the animal from a feed. The NRC (2000) calculated values of TDN from a linear regression that did not reveal this. The ratio of ENE to TDN declines in relation to the increase in plant cell concentration, or [NDF]. In the case of increased $[\mathrm{NDF}]$, more energy is required of the animal and the rumen microbes in order to break down the forages. It has been shown that grinding forages can lower the heat increment, and increase the energy efficiency, which increases the propionate to acetate ratio by exposing more surface area to degradation by rumen microbes (Van Soest, 1994).

Some factors that cost energy to the animal at maintenance are environment, work, and grazing (Van Soest, 1994; Waldo et al., 1961). The combination of the act of grazing, the increased time required for the mechanical action of digesting whole forages, and the level of fiber in the diet, all lead to an increased heat increment, and therefore lower energy efficiency in the grazing ruminant animal.

Varying functions (maintenance, lactation, growth, or fattening) have different degrees of efficiency when it comes to using energy. Weight gain is the least efficient function, whereas maintenance and lactation are the most efficient (Van Soest, 1994). However, it is also important to note that, while lactating may be more energy efficient, it is also more energy demanding compared to the other functions (Oklahoma Cooperative Extension, 2000) as demonstrated by the fact that, on a forage diet, lactating cows increase DMI by a mean of 30\% (Minson, 1990).

The metabolizable energy system takes into account the differing efficiencies, more so than TDN or NE, and is easier to measure than NE, but only if representative 
output values for feces, urine, and methane can be obtained (Van Soest, 1994). These output values are subtracted from the gross feed energy in order to obtain a value for ME (Saha et al., 2013) and determine the correct production of VFA (acetate to propionate). With this in mind, energy is not only important to the animal but also to the rumen microbes. If the microbes do not have an adequate amount of vitamins, minerals, and energy, then they cannot flourish (Sewell, 1993). No matter what measurement is being used to quantify it, energy in itself is the single most important nutritional factor to consider when evaluating the diet of beef cattle (George et al., 2001b).

\section{vi. Feed value indices}

Various methods and terminology exist with the purpose of indexing the value of feeds to cattle. As of the late 1900's, there were minimal data detailing the nutritional composition of native and non-native grasses. Techniques that used common forage cultivars in indoor feeding experiments were not well-refined or applicable to freegrazing cattle consuming multiple rangeland species (Ulyatt, 1973).

Three main ranking systems exist for determination of forage value: 1) nutritive value (NV), 2) relative forage value (RFV), and 3) relative forage quality (RFQ). Kellaway et al. (1993) and Ulyatt (1973) define nutritive value as the "concentration of nutrients in the forage, or as animal production response per unit of feed consumed." Ulyatt (1973) ranked nutritive value of forages as "high", "medium", and "low". Nutritive value is based upon the percent forage in the diet as well as the percent contributed from fiber to the digestible energy (DE; Pearson and Ison, 1997), but cannot be determined by these measurements alone as NV and animal intake are highly 
interrelated (Ulyatt, 1973). Feed intake is an important variable in equations for predicting the nutrient requirements of livestock and their rate of gain in feedlot and/or pasture conditions (NRC, 2000), and is limited by digestibility (Pearson and Ison, 1997). If the digestibility of a given forage is known, this can help to classify it as either high, medium, or low NV. However, due to complex interaction of factors determining NV, some forages of a similar digestibility, may produce differing NV's (Ulyatt, 1973). The factors determining NV fall under three large categories: animal factors, environment, and pasture attributes (Pearson and Ison; 1997). The animal factors (i.e., type, size, and level of production) affect potential daily intake. The addition of environment (weather and day length; NRC, 2000) and pasture attributes (primarily forage quality) dictates the actual daily intake (Pearson and Ison, 1997).

Unlike the broad classification system of NV, RFV is an index based on a series of calculations appropriately developed for ranking cool-season grasses, legumes, legume-grasses, and hays and haylages (NFTA, 2007). It is based primarily upon an interpretation of \% $\mathrm{ADF}$ and $\% \mathrm{NDF}$ values in determination of dry matter digestibility (DMD) and DMI values. The National Forage Testing Association (2007) uses DMD and DMI to calculate RFV. Alfalfa hay in late reproductive stage is used as the basis for comparison with a RFV of 100, above 100 being higher quality.

$$
\begin{gathered}
D M D=88.9-(.779 \times \% A D F) \\
D M I=\frac{120}{\% N D F} \\
R F V=D M D \times \frac{D M I}{1.29}
\end{gathered}
$$


Additional factors, such as energy intake provide the basis for comparison between two or more forages in the RFQ equation (Saha et al., 2013), where:

$$
R F Q=D M I(\% \text { of } B W) \times \frac{T D N(\% D M)}{1.23}
$$

While still using a basis of comparison of 100, like RFV, RFQ is a better predictor of forage quality because it accounts for fiber digestibility. By including TDN, it also includes neutral detergent fiber digestibility (NDFD; Saha et al., 2013), CP, energy efficiency (EE), and non-fiber carbohydrates (NFC; UCD, 2008). Ultimately, the value of forages to cattle cannot be determined without intimate knowledge of the animal and the forage, as well as their environment. 


\section{Section III}

Seasonal changes affect the amount and composition of forages available, making it difficult to control animal diet selectivity. Depending on the climate and geographical location of a given pasture, forage species will vary in nutritive value. Nutritive value will additionally be affected by the selectivity of cattle (Ulyatt, 1973) especially because cattle can show preference for particular plant species, stages of growth, and plant structures (Reid, 1973). Sheep selectivity is determined by the plant species that are consumed more quickly than others (Kenney and Black, 1984), which includes the plant structure, that are more easily digested. Palatability is a primary factor for determining animal intake and performance. Managing for animal performance (secondary productivity) cannot be addressed without also managing the available forages (primary productivity), as the two components are highly interrelated (Soder et al., 2009). Where primary productivity is a function of range forage composition, secondary productivity is a function of cattle grazing selectivity of available forages. Both of these factors can be manipulated by the land manager.

\section{i. Animal behavior in regards to grazing selectivity and palatability}

The selectivity and palatability of a plant can result from plant structure, growth stage and species. Most grasses tend to be palatable and nutritious when they are in the vegetative stage (Jones and Love, 1945). Naturally, plants do not remain in vegetative stage and, therefore, develop varying levels of palatability as they mature. Testing aspects

of palatability provide insight to cattle preferences. Wilson (1986) and Hodgson (1986) reported that the physical aspects of diet, such as plant structural strength (i.e. shear 
strength, Sun et al., 2010), affect diet selection. Mixed ages of plants, growing and senescing, also affect animal selectivity (NRC, 2000 Ch.7; Minson, 1990). Most often, cattle will select the plants that are growing over those that are senescing (Minson, 1990). Also, the morphological characteristics of a plant species and how densely the individuals grow to one another will impact the animal intake (Van Soest, 1994).

In regards to selectivity, observations from a study conducted on the San Juaquin experimental range between the years of 1946 and 1957, reported that rows of Nasella pulchra, purple needlegrass, were grazed and alternate rows of Nasella cernua, nodding needlegrass, were only slightly grazed in November of 1953, (Green and Bentley, 1957). By the end of the winter, (February 1954) all rows had been uniformly grazed (Green and Bentley, 1957). It was also observed that cattle would graze the new growth of the Nasella spp.with the dry annuals in May and June 1952, but ignored the dormant or late reproductive Nasella spp. (Green and Bentley, 1957). Green and Bentley (1957) documented that purple needlegrass was most palatable in winter compared to annual grasses. Another perennial species that is highly palatable, and was historically abundant on the central coast, is California oatgrass. It is a long-season grass that has encountered severe reductions due to farming and overgrazing (Jones and Love, 1945).

Selectivity and palatability can also be related to chemical composition. A major deterrent to the consumption of a plant can be attributed to phenolic compounds, also known as alkaloids (Reid, 1973). Palatability and the animal's level of attraction to a plant has been linked to protein content, digestibility or mineral content (Senft, 1989). Cell contents from of four varieties of ryegrass demonstrated a high, positive relationship 
with consumption by steers and heifers and a negative relationship with NDF (Aderibigbe and Church, 1980).

Several hypotheses regarding the tendencies of cattle to selectively graze more highly nutritious plants were tested. Crude protein (CP), neutral detergent fiber (NDF), acid detergent fiber (ADF), and in situ dry matter disappearance (ISDMD) were mapped throughout a spatial distribution of several pastures. The responses of cattle to forage quantity/quality dynamics demonstrated that the selectivity of cattle favored forages containing above average CP and ISDMD values. Cattle tended to select forages containing below average NDF, but had no preferences based on ADF content of plants (Ganskopp and Bohnert, 2009).

Several factors can contribute to selectivity and palatability within the sward. The species of grazing animal has a particular palate (Reid, 1973), which has an impact on the percentage of forage available that will be eaten. Leigh and Mulham (1966) found that $80 \%$ of the diet of sheep grazing semi-arid pastures in New South Wales, Australia, was composed of $1 \%$ of the forages available. The selection choices made by the animal are highly dependent upon the diversity of plant species already available (Van Soest, 1994). Allowing more opportunity for selection increases the likelihood that cattle will consume a higher quality diet (Pearson and Ison, 1997). Selection has the potential to be extremely high if time or space allows, but can be minimized by stress (grazing pressure, competition, hunger, etc.) or uniformity of the sward (Van Soest, 1994; Senft, 1989). According to Senft (1989), the already established plant composition of a rangeland ecosystem has a greater influence over the future patterns of landscape use than grazing management. 
Within the home range (Figure 2.2; Senft, 1989) cattle tend to make selections based upon experience, forage type, forage quantity, and forage quality (Villalba et al., 2015). Most often the animal will base foraging decisions on spatial cues prior to plant species or even plant parts (Stuth, 1991). Subdividing pastures can be beneficial in that it disrupts the tendency of cattle to first select a home range (Senft, 1989).

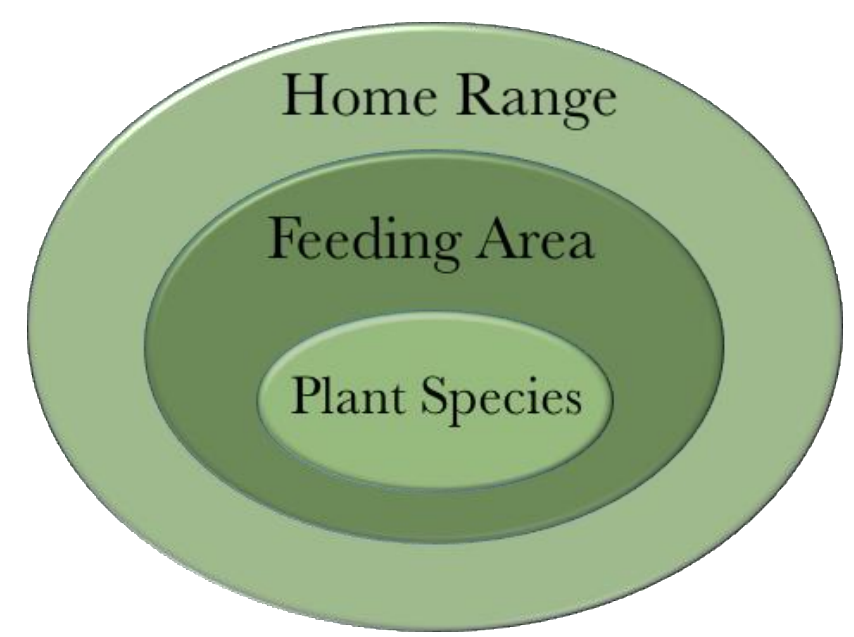

Figure 1.2. Representation of hierarchical order of selection by cattle with "Home Range" being the top order (adapted from Senft, 1989).

Animal species also affect sward height. Cattle are known to graze no closer than $1-1.5 \mathrm{~cm}$ from the ground, due to their anatomical mouth structure (i.e., an intact upper lip and thick lower lip), which limit grazing height. Sheep are capable of grazing much closer to the floor as their split upper lip and mechanical action of their incisors against their dental pad allow them to cut forage (Reid, 1973). Van Soest (1994) discusses the complementation resulting from utilization of various forage species when animals select a diet within a single pasture. This strategy has shown to optimize the use of forages and a greater breadth of forages available (Van Soest, 1994). In order to impact the grassland and/or rangeland ecosystem, various grazing management strategies can be used that take advantage of the dynamic interactions between animal and plant (Reid, 1973). 


\section{ii. Using grazing behavior as a tool}

Reduction of selectivity can be completed by increasing the grazing pressure with higher stocking rate. Otherwise, minimal grazing and low stocking rate will allow for maturation of plants and possible wasted forage (Van Soest, 1994). Cattle will begin grazing the nearest available forage and the movement of the herd will naturally gravitate to the water supply. Areas that provide water also tend to have plants containing high nutrient concentrations; thus, the closer to a water source, the higher the carrying capacity will be (within 1 mile $=$ approx. 47 animal carrying capacity/animal unit (AU) year-long; within 2 miles = approx. 38 animal carrying capacity/AU yearlong; Jones and Love, 1945).

Applying strategies for prevention of over-grazing and trampling of plants around water sources is important to prevent erosion and contamination of water sources (Van Soest, 1994). One might consider building fence around these areas, or moving animals in a high intensity, short duration system. In addition, cattle and sheep should be limited to traversing more than 2.5 miles of rolling foothill ranges to access water (Jones and Love, 1945).

Another option for limiting the selectivity of grazers is through the introduction of highly competitive species, such as many of the annuals seen on California rangelands, which can eliminate other competitors. The addition of highly palatable species may increase primary production of a pasture and the amount of energy provided to the grazing animal, but may not necessarily benefit the ecosystem (Briske and Heitschmidt, 1991). From another perspective, in the early spring, when most annual species are in early or late reproductive stage, they may protect remnant perennial species by being 
more palatable and therefore grazed first (Jones and Love, 1945). However, this is dependent upon the season and does not take into account the competition for light, moisture, and nutrients between annual and perennial species. The decision to add or retain annual species should be weighed accordingly.

\section{iii. Matching animal production with plant production}

Animal production can be enhanced by implementing management systems that align with production goals. Benefits include increased health via reduced parasitism within the herd and adequate consumption of trace minerals (Villalba et al., 2015; SARE, 1999). Most commonly, the goal of managing livestock is to increase net profit through improving animal performance. This can be achieved by balancing the changing nutritional needs of the cyclic cow with seasonal fluctuations in nutrition of forages available (George et al., 2001b; Van Soest, 1994).

Within the beef cow production year there are about five stages in the cow reproduction cycle. At each stage, but especially late gestation and post-partum, the cow requires a specific level of nutrients to achieve a high level of performance and to produce healthy offspring. In order to most closely meet the changing nutrient requirements of the cow, each of the five stages should be aligned with four stages of grass growth. Predominantly annual-based grasslands are not capable of providing the cow with adequate nutrients year-round (George et al., 2001b).

Calving at different seasons (fall or spring), depending on location, are some strategies used for planning around these seasonal trends (Figure 1.3) in order to provide the cow and calf with adequate nutrient supplies from forage. Meeting the needs of the 
cow and calf can be easily achieved on adequate green forage (Figure 1.3; George and Fulgham, 1989).

\section{Seasonal Forage Production}

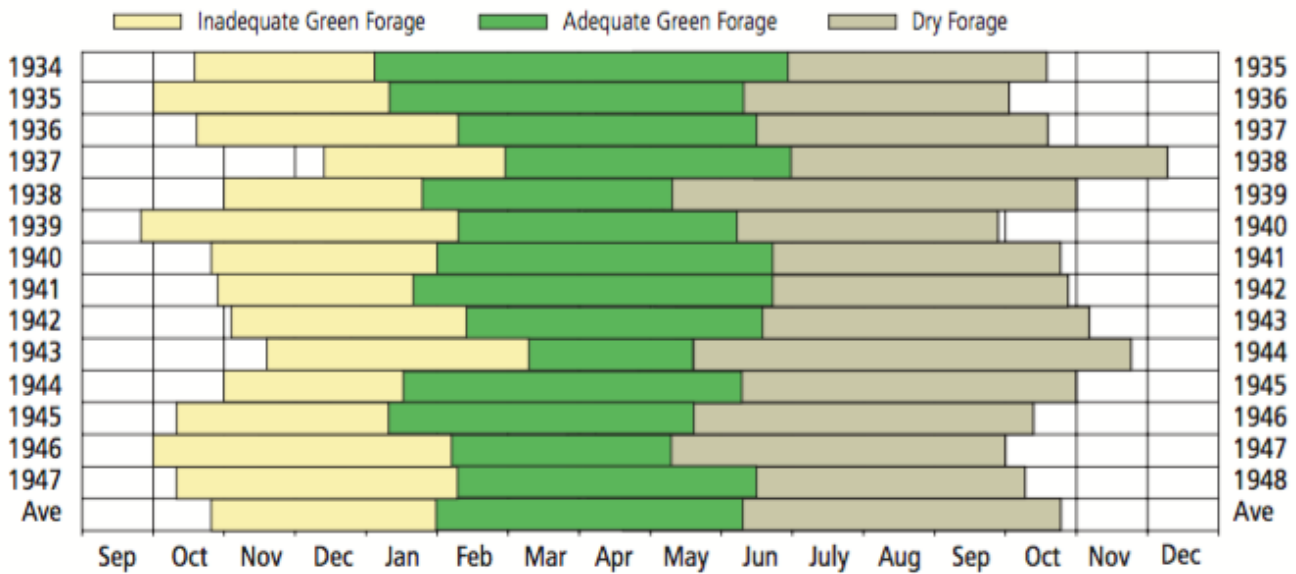

Figure 1.3. Seasonal forage qualities and quantities recorded from 1934 to 1947 at the San Joaquin Experimental Range (SJER) (George et al., 2001a).

Beef production operations vary throughout California and management calendars are dependent upon location. Fall calving is typically done in the Central Valley or Central Coast of California due to earlier onset of summer, which causes forage quality to decline sooner. Late winter or early spring calving typically occurs in the northern coastal, mountainous, or inter-mountain areas due to the more extreme winter conditions being undesirable for newborn calves and later onset of palatable vegetation. The fall calving season typically corresponds with the calves being born between September and November when green forage is beginning to appear (George and Fulgham, 1989). A specific starting point, within this 3-month range, can be determined in part by using the knowledge that annual forage will sprout up rapidly if temperatures are in the $15.6^{\circ}$ to $26.7^{\circ} \mathrm{C}$ range. If temperatures are between $4.4^{\circ}$ to $10^{\circ} \mathrm{C}$ for the majority of the season, then annual forage will sprout up gradually. Based on pounds of forage production in a 
season, relative to the DMI capacity of a dry and lactating cow, one can approximate how many head a given pasture can support. Data from the San Joaquin Experimental Range (SJER; O’Neals, CA) show that during an average fall (November $7^{\text {th }}$ ) an acre of land produced $600 \mathrm{lb}$ of forage from annual grasses in vegetative stage (George et al., 2001b), which can support 20 dry cows and 18 lactating cows for one day (Oklahoma Cooperative Extension, 2000). During a warm, wet fall (November $7^{\text {th }}$ ) at the SJER, an acre of land produced $1000 \mathrm{lb}$ of forage (George et al., 2001b) that could support 33 dry cows and 30 lactating cows for one day (Oklahoma Cooperative Extension, 2000). These estimations have not subtracted the amount of residual dry matter that should be left behind.

The winter or early spring calving season generally commences in January and ends in March, when conditions begin to warm up to $7.2^{\circ} \mathrm{C}$, or greater, and vegetative growth appears rapidly. Data from the SJER show that forage production increases from November to May. The maximum amount of late reproductive forage one acre produced was 3000 pounds (George et al., 2001b), which could meet the DMI capacity of 125 dry cows and 100 lactating cows (Oklahoma Cooperative Extension, 2000) for one day. The minimum amount produced on May $1^{\text {st }}$ at the SJER was $1000 \mathrm{lb} / \mathrm{acre}$ (George et al., 2001b), and would fill the DMI capacity of 41 dry cows and 33 lactating cows, but with a lower quality forage (Oklahoma Cooperative Extension, 2000).

Beef stockers are brought to California rangelands to graze on the fall and early winter forage growth, similar to the cows calving in fall (George et al., 2001a). The number of beef stockers or calves retained on California pastures is highly dependent upon the precipitation, which affects the forage quantity in a given year. Up to $50 \%$ of 
weaned calves may be retained by the owner over a second growing season (George and Fulgham, 1989). This scenario is most likely to occur following a warm, wet spring and if calves were born at a $75 \mathrm{lb}$ and gained $1.4 \mathrm{lb}$ (heifer) /1.6 lb (steer) per day until weaning (7 to 10 months) (George et al., 2001a).

Highly dynamic forage production in conjunction with changing nutrient requirements of reproducing cows can make it difficult to manage livestock on rangeland. However, there are ways land and livestock managers can have some control over the amount of forage available, which may help to estimate their profits. Dunn et al. (2010) estimated net profits by classifying rangelands. They found the 'good' to produce better profits ( $\left.\$ 29.43 \mathrm{ha}^{-1}\right)$, compared to 'low-fair' $\left(\$ 27.61 \mathrm{ha}^{-1}\right)$ and 'excellent' rangeland $\left(\$ 23.01 \mathrm{ha}^{-1}\right)$. However, this study did not address the nutritional profile of forages available to cattle during each season.

A study by Hart and Ashby (1998) looked at the types of plants grazed and the effects that the grazing had on, not only the performance of the animals, but also the plants. The resulting biomass of warm season grasses was recorded at each grazing intensity (heavy, moderate, and light) and responded best at the moderate level. Managing for good range condition levels with moderate grazing intensity appears to provide optimum returns to the rancher in terms of primary and secondary productivity (Dunn et al., 2010; Hart and Ashby, 1998). Management of specific annual and perennial plants that provide optimal nutrient levels year-round may increase yields further.

\section{iv. Management for specific grass species}

In order to balance the nutritional needs of the animal with the nutrients provided by the forage, Jones and Love (1945) have tested how to produce the highest possible 
yield of palatable and nutritious feed over the longest duration of time. As forages mature, forage quality decreases. While more DM may be produced from a pasture, the quality of that DM is continually less desirable after a certain level of maturation. In a meta-analysis, George and Bell (2001) showed that on California ranges CP, calcium, and phosphorus decreased with maturity, while CF increased. More importantly, forage maturity was strongly correlated with $\mathrm{CP}$; therefore, it is a good predictor of forage $\mathrm{CP}$ levels. This relationship was also found in annual grasses such as annual fescue (Festuca megalura), ripgut brome (Bromus rigidus), soft chess brome (Bromus mollis), Australian chess (Bromus arenarius), wild oats (Avena barbata), and red brome (Broums rubens) (George and Bell, 2001).

Soft chess (Bromus hordeaceus) is the most nutritious and most palatable (60\%; Hormay, 1940) for cattle of the annual grass species found on California rangelands. Its CP levels decline more gradually (from $24 \% \mathrm{CP}$ ) and remain higher between late reproductive stage and dry stage ( $8 \%$ to $13 \% \mathrm{CP})$, while containing higher energy and mineral content compared to other species. The large, plump seeds linger on the plant long after the plant has reached the dry stage, providing continued nutrition to cattle beyond the growing season (George and Bell, 2001). From the vegetative to the early reproductive stage, soft chess (Bromus hordeaceus) contains roughly $28 \%$ to $30 \% \mathrm{CF}$ (George and Bell, 2001), however, CF is highly variable within late reproductive and dry stage (22\% to 39\% CF; George and Bell, 2001).

Purple needlegrass (Nasella pulchra), responded noticeably better to the earlier, shorter grazing as opposed to the later and longer grazing. Jones and Love (1945) concluded that improper timing of grazing led to overgrazing. Perennial species are more 
susceptible to overgrazing as their slower growth pattern limits their ability to compete amongst annual species. Compared to perennial species Danthonia californica and Nasella lepida, N.pulchra appeared to be the most tolerant to grazing. In some cases, particularly spring grazing (Figure 1.4), purple needlegrass demonstrated a positive response (Bartolome et al., 2004) and in other studies it was indifferent to clipping and grazing (Lulow, 2008; Hatch et al., 1999).

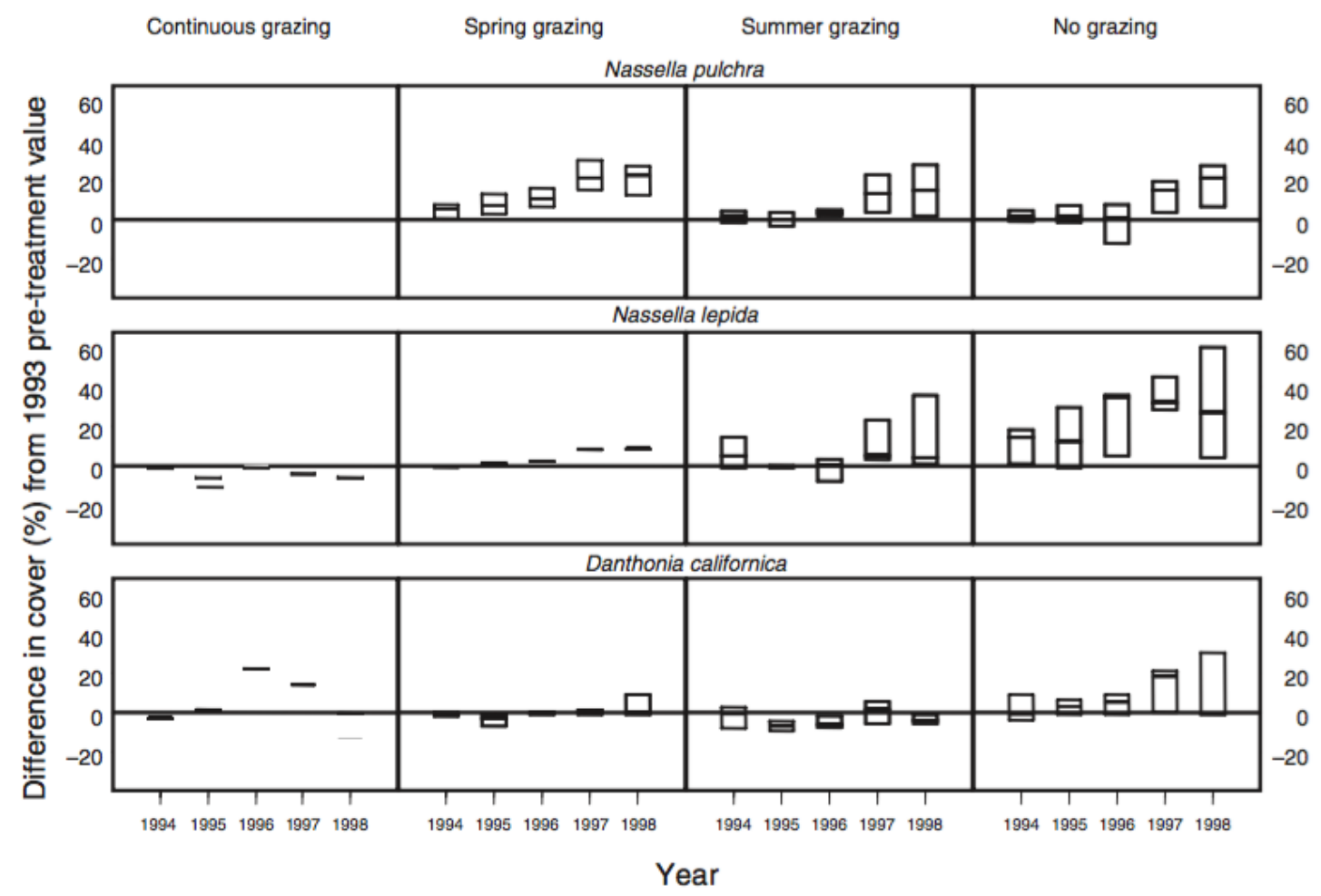

Figure 1.4. Boxplots represent the percentage cover of perennial grasses in response to various levels of grazing compared to baseline. Nasella pulchra was not present in the continuously grazed plot (Bartolome, 2004).

One goal of rangeland restoration may include the elimination of weedy annuals (foxtail barley, ripgut brome) to encourage the growth of more palatable annual grasses (soft chess) and perennial grasses (Nasella spp., California oatgrass, perennial ryegrass) and forbs (bur clover and filaree). The starting point may be a barren landscape in which 
case rest is recommended, followed by reseeding with desired species when soil is prepared, and lastly with grazing to allow for the seeds to make close contact with the soil. Another starting scenario may be a pasture containing weedy annuals. In this case, a pasture rotation system should be developed in which 3-4 pastures are grazed in the early spring, allowing each pasture to rest at least every $3^{\text {rd }}$ year in the cycle, depending on how severely it was grazed. Grazing in the early spring minimizes seed distribution of annuals such as foxtail barley and ripgut brome before they become dry and potentially harmful to the animal. Simultaneously, perennials will be grazed while they are still in vegetative stage, allowing them to grow better, as seen through grazing and mowing experiments (Jones and Love,1945).

Grazing with the intention of improving the effective leaf-area index (a way of quantifying plant canopy cover) will result in higher grazing pressure, which causes the plant to respond in such a way that the digestibility increases because such stresses cause decreased lignification during subsequent re-growth (Van Soest, 1994). Therefore, grazing inhibits the maturation of forages and increases the overall nutritive value of a pasture. Following grazing, grasses will respond with increases in photosynthetic material (more leaves) and diminished extraction of soil moisture. This slows maturation of perennials, and annuals, so they can retain a higher nutritional value for a longer period of time; thus, helping to extend the grazing season (Jones and Love, 1945).

If the duration of grazing is timed correctly, cattle will select the more palatable annuals first and graze the perennials less severely, allowing for the re-establishment of perennial bunches. Cattle must be removed in time to spare perennials and also leave some cover on the ground in order for soil moisture to be retained so that perennials, 
filaree, and bur-clover will still have water to continue growing. Subdivisions of pasture assist the rancher in setting a desired stock density/grazing pressure in order to maximize the use of available forages. The less palatable the forage, the heavier the cattle should be stocked. More frequent rotations are most beneficial to restoration efforts (Jones and Love, 1945; Henneman et al., 2014).

\section{v. Supplementary feeding}

Supplementation is an especially important strategy used for cattle operations in California to implement in the summer months. During this time, standing forages are especially low in CP; therefore, cattle should be provided supplementation protein such as cottonseed cake or meal (Jones and Love, 1945; Hersom, 2008), safflower, oil meal (George et al., 2001b) and alfalfa (Weder et al., 1999) in order to offset nutrient deficiencies and maintain adequate animal performance (Waterman et al., 2014).

Urea $\left(\mathrm{CH}_{4} \mathrm{~N}_{2} \mathrm{O}\right)$ is also another useful source of protein supplementation. While it is a non-protein nitrogen (NPN) source and does not provide protein directly to the animal, the microbes in the rumen are able to use the nitrogen from the compound to create microbial protein (George et al., 2001b; Sewell, 1993). When supplementing urea to cattle fed a high forage diet, it is important to be aware of the energy content of the feed, as forages are generally lower in energy content than concentrate feeds. This can be a limiting factor for the rumen microbes in their ability to thrive and successfully produce ammonia and microbial protein (Sewell, 1993). High energy, grain-based supplements will likely shift the balance in rumen microorganism populations (El-Shazly et al., 1961). Cattle fed a low energy diet in combination with urea supplementation may suffer from toxicity. Rumen microbial populations adapted to low-quality forages would not be 
established to recycle large portions of urea. To compensate, the liver would process the majority of the urea (Sewell, 1993). However, it has been reported that, of the urea produced by beef steers consuming high forage diets, $80 \%$ was recycled (Huntington et al., 2009).

The use of rumen-protected (a type of RUP) amino acid (AA) supplementation has increased recently. This is a way for cattle managers to control what AA's are available for absorption through the intestine. Primiparous beef cows consuming annual rye hay have shown increases in milk yields when supplemented with rumen-protected lysine and methionine (Hess et al., 1998) and heifers grazing kikuyu (Pennisetum clandestinum) pasture demonstrated improved growth following supplementation with urea, blood-meal, and rumen-protected methionine (Gomez et al., 2011). While rumenprotected amino acid supplementation has been researched thoroughly and utilized for feedlot cattle, less is known about the specific amino acid needs of grazing beef cattle (Waterman et al., 2014).

A possible supplementation strategy that has been suggested for use in forage-fed diets is that of nutrient synchrony, the idea that microbial efficiency can be optimized via the providing of $\mathrm{N}$ and energy concurrently with other nutrients (Hersom, 2008). While opposing results have been demonstrated through various studies, the research of this concept is multidimensional and complex, depending on many variables and situations. However, the potential for use and improvement in the performance of grazing cattle remains. Hersom (2008) has outlined the results of several studies such as those from Bohnert et al. (2002a, b, c) and Moore et al. (1999). A positive result of nutrient synchrony was seen from increasing the frequency of feeding protein supplements from 
2-7d/wk, which coincided with a linear increase in OM and NDF digestibility (Bohnert et al., 2002a, b, c). It has been advised that nutrient synchrony may elicit a greater response when animals graze low-quality forage matched with a supplement of similar degradation rate (Hersom, 2008). It is possible that, if provided with a high energy-based supplement, the animal can receive a larger portion of the energy in its diet from the supplement, therefore decreasing the DMI of available forage (Van Soest, 1994; Hersom, 2008). Moore et al. (1999) have stressed that forage DMI improves from supplementing with protein or energy when the TDN to $\mathrm{CP}$ ratio of the forage is $>7 \%$. As a livestock manager, it is important to know the forage-base of the pastures so that an approximation of chemical composition of the pasture can be determined and assist with deciding on the best supplement(s) to use (Hersom, 2008). 


\section{Section IV}

The literature supports the conclusion that, perennials grasses may not have a higher nutritional value than annuals, in all cases, across all growth stages, despite the fact that perennial grasses exhibit prolonged metabolic activity. One common conception amongst ranchers is that because of their green appearance, perennials have a higher nutritional value than annual grasses in the summer, and are therefore a source of standing forage that can be utilized and beneficial to the performance of grazing cattle. However, if the rancher of an extensive grazing system is concerned with the long-term production of his land, then perennial species should not be grazed post-spring. This practice will allow perennials to come back strong in the following fall and winter. This is also best for the animal because early grazing eliminates unwanted annual grass species over time. It also allows defoliation of perennials, while in vegetative or early reproductive stages, and stimulates regrowth with less structural components and higher digestibility. Defoliation of annual grasses at this time can prevent the annuals from going to seed, therefore reducing competition for perennials in the following growing season. In California, grass species, such as the perennial California oat grass and annual soft chess, are of high nutritional value, palatability to cattle. However, in the summer months, grazing cattle, particularly lactating cows, may still need supplementation. Stockers that are gaining and cows that are lactating or gestating in the winter may need supplemented depending on pasture quality and soil nutrient characteristics of a given area. Choice of supplement is dependent upon the current requirements of the animals and the environment they are in. In order to make the most informed economic and environmental decisions on this matter, and to develop prediction equations and practical use of strategies such as nutrient 
synchrony, further research on forage nutritional composition, and techniques for how to efficiently gather such data, must be conducted. 


\title{
METHODOLOGY \& ANALYSIS
}

\author{
Section I. Materials
}

\section{Plant Samples}

Nine plant species, (Table 2.1) (Avena spp., B. hordeaceous, E. botrys, L. multiflorum, E. glaucus, L. tritichoides, Melica spp., S. lepida, S. pulchra) (USDA-NRCS, 2017) were collected at four growth stages (Table 2.2) in San Luis Obispo county, California (Appendix A). Eight plants were grass species and one plant, E. botrys Broadleaf filaree, was a forb.

\section{Livestock}

Two lactating cannulated Angus cows, owned by California State University, Chico were utilized for ruminal incubation of plant samples.

\section{Section II. Methods}

\section{i. Plant Sample Collection}

Plant samples were collected at four of the most morphologically distinguishable growth stages of the twelve standard stages of maturity used by George and Bell (2001). The four growth stages and their characteristics are as follows. Late vegetative (LV) plants consisted mostly of leaf material and, of the stem material, internodes were beginning to lengthen. The early reproductive (ER) plants had reproductive structures that were not fully matured (i.e., seeds in milk stage) and anthers were still present. The

plants at late reproductive (LR) stage were fully mature, and seeds were being cast from 
the inflorescence. Lastly, the dry (D) plants were completely dried out, with the exception of perennial plants, which contained some pigmentation at the bottom 4-8 in. of the tiller. Detailed parameters for distinguishing growth stages are shown in Table 2.2 and were adapted from NRC (1982). The samples were all collected between May 2016 and April 2017 using the grass collection procedures described in Appendix A, which were designed specifically for this project by the main author. Quality control measures included sorting and separating RDM, desired grass species and accurate growth stage. A minimum of 300 grams dried and ground plant material were required for each species in the experiment.

Plant sample collection began in May 2016 within San Luis Obispo County. A single county was selected to limit variation in soil and climatic factors. Collection locations (Appendix B) were not randomized, but rather, selected based on the presence and abundance of the sample species. The perennials, purple needle grass, foothill needlegrass, and purple needlegrass were all characteristic of bunchgrasses and maintained some active tillers year-round. All the annual grasses grew independent culms and were completely dried by August. The LR and D stages of all species were collected through July. All four growth stages of the perennials, blue wildrye and creeping wildrye were collected by August 2016. The LV and ER stages for the remainder of the plant species were collected between January 2017 and April 2017 (Table 2.4).

Identification of grass species was dependent upon the growth stage structure of the grass species. Late vegetative stage was more difficult to assess in soft chess, foothill needlegrass, and blue wildrye due to loss of distinctive characteristics; thus, the selection process was based on species' preferred location, presence of dried old tillers or new 
ones, and the ligule, auricle, and configuration of the sheath (i.e., open, fused, overlapping).

Quality control measures included sorting and separating RDM, desired grass species and accurate growth stage. A minimum of 300 grams dried and ground plant material were required for each species in the experiment. 


\section{ii. Plant Sample Preparation}

Samples were dried at $80^{\circ} \mathrm{C}$ (Kalra, 1998) for 24 to $48 \mathrm{~h}$ and subsequently run through a Wiley mill (Thomas Scientific. Thomas Wiley Mill, Model 4. Swedesboro, NJ) and ground to $4 \mathrm{~mm}$ sized particles. The Wiley mill was cleaned thoroughly between sample grinding to avoid contamination. Samples were stored individually by species and growth stage in large $92 \mathrm{oz}(25.4 \times 38 \mathrm{~cm})$ Whirlpak ${ }^{\circledR}$ bags (Nasco, Modesto, CA) at ambient temperature until preparation for in situ digestibility trials. Sample preparation for in situ digestibility trials was similar to Buckner et al. (2013). An aliquot of each of the 4-mm samples was processed through a 1-mm screen in the Wiley mill for lab analysis.

\section{iii. In-situ Digestibility Trials}

Procedures to determine in situ digestibility were similar to (Buckner et al., 2013). Briefly, $9.5 \mathrm{~g}$ to $10 \mathrm{~g}$ of $4 \mathrm{~mm}$ ground plant material from each grass species and growth stage, in addition to soybean meal control, were measured into $10 \times 20 \mathrm{~cm}, 50$-micron porosity in situ bags (Ankom Technology, Macedon, NY). Four replicates and a washout bag were used for each sample and the control at each time-point (hour 12, 24, 48). Bags were secured with nylon string by using a hangman's knot. The four replicate in situ bags were placed into a larger mesh bag for each time-point. Samples from each time point were evenly and randomly divided among two separate mesh bags, resulting in 68 samples per bag and six mesh bags per cow. Time-point mesh bags were identified via specific-colored nylon rope secured to the mesh bag and outside of cannula. Three colors of nylon string were used (red, blue, and yellow) to represent each time point. 
Two ruminally-cannulated Angus cows were removed from pasture and fed a base alfalfa diet $(20.81 \% \mathrm{CP}$ and $0.25 \mathrm{Mcal} / \mathrm{kg} \mathrm{NEl})$ ad libitum for 14 days prior to in situ incubation period. They were held off feed for $12 \mathrm{~h}$ prior to start of the trial, but were allowed alfalfa hay throughout the experiment. Six mesh bags were placed directly into the rumen. Each set of two bags, representing one time-point, was removed at its designated time-point (i.e., 12, 24, or $48 \mathrm{~h}$ ) after insertion into the rumen, for determination dry matter digestibility (DMD) and organic matter digestibility (OMD). Immediately following the removal of mesh bags at each time point, individual sample bags were placed in cold water to slow microbial activity and were thoroughly rinsed until the rinse water was clear.

All ANKOM in-situ sample bags were placed in the oven for approximately 72 hours at $100^{\circ} \mathrm{C}$ and then stored in large $92 \mathrm{oz}(25.4 \times 38 \mathrm{~cm})$ Whirlpak $^{\circledR}$ bags (Nasco, Modesto, CA) until they were weighed. Bags were weighed no sooner than 30 minutes after being removed from the oven. Acceptable samples were within a $10 \% \mathrm{CV}$.

\section{Section III. Chemical Composition}

\section{i. Dry Matter and Ash}

The DM and OM content of all samples were determined through a gravimetric procedure developed by the Cal Poly Nutrition Laboratory (Appendix D). Sub-samples were drawn from $4 \mathrm{~mm}$ ground plant sample. Duplicates were made for each sample type and crucibles containing sub-samples were placed into a forced-air drying oven at $100^{\circ} \mathrm{C}$ for $24 \mathrm{~h}$. After determination of DM, crucibles were placed into a Thermolyne Tabletop 
Muffle Furnace, (Thermoscientific, Waltham, MA) and heated to a maximum of $600^{\circ} \mathrm{C}$ for $2 \mathrm{~h}$ during the $15 \mathrm{~h}$ ashing process. Acceptable samples were within a $1 \% \mathrm{CV}$.

\section{ii. Nitrogen Analysis}

Plant samples, ground to $1 \mathrm{~mm}$, weighed into crucibles and analyzed for $\mathrm{N}$ content using the vario Max CNS, Macro Elemental Analyzer, (Elementar Analysenesteme GmbH, Hanau, Germany). Every-other sample was run as a duplicate and every ten samples were tested against a standard plant sample. Standards for the first and second set of samples were $2.9 \% \mathrm{~N}$ (tomato powder) and $1.065 \% \mathrm{~N}$ (pine needle powder), for the first and second set of samples, respectively. Pine needles had a nitrogen content closer to that of the plant samples being analyzed. Acceptable samples were within $5 \% \mathrm{CV}$.

\section{iii. Fiber Analysis}

Fiber analyses were sequentially ran according to Method 6 for NDF, Method 12 for ADF, and Method 8 for ADL, Ankom Technology, (Mecedon, New York). Procedures were based on methodology described by Van Soest (1994). Plant samples, ground to $1 \mathrm{~mm}$ (Thomas Scientific. Thomas Wiley Mill, Model 4. Swedesboro, NJ), were weighed into F57 Ankom, Fiber Filter Bags, and were analyzed using the Ankom 200 Fiber Analyzer (Macedon, New York). Heat-treated, alpha amylase was added for NDF analysis. Sodium sulphite was excluded from NDF analysis, in order to preserve the lignin component of the sample for ADL analysis. Following each analysis, samples were dried $\left(100 \pm 2^{\circ} \mathrm{C}\right)$ via a digital forced-air drying oven (Quincy Lab Corporation, Chicago, 
IL). Final sample weights were recorded and calculated as \%NDF, \%ADF, \%ADL, and were corrected for \%DM. Acceptable samples were within 5\% CV.

\section{Section IV. Statistical Analysis}

The experimental design was a CRD with fixed effects of growth stages and growth type. Initial plant descriptive data (i.e., raw means) were analyzed via PROC MEANS procedure in SAS (version 9.1.4; SAS Institute Inc., Cary, NC). Data were analyzed with The MIXED procedure of SAS using a two-way ANOVA test to evaluate effects of stage, type, and stage $\mathrm{x}$ type. There was no stage $\mathrm{x}$ type significant interaction. Therefore, only main effects were analyzed. Means were generated using LSMEANS statement. Growth type effects on CP, NDF, ADF, ADL, DM, OM, ash, aNDFom were analyzed with an F-Test. A linear contrast was used to describe maturing growth stage on CP, NDF, ADF, ADL, DM, OM, ash, aNDFom. Statistical analysis of the data from the in situ trials used individual plant sample as the experimental unit. Data were analyzed using The MIXED procedure of SAS with repeated measures to test the effects of in situ time period (time), stage, type and all subsequent interactions on DMD and OMD. The covariance structure, compound symmetry, was chosen on the basis of the lowest Bayesian information criterion. The subject was cow nested within time. Means were separated compared using the LSMEANS command and PDIFF statement in SAS. If a significant interaction was observed, the SLICE procedure in SAS was used to separate stage, type, and time effects within hour. Significance was declared at $P \leq 0.05$. Trends were discussed at $0.05<P<0.10$. 


\section{RESULTS}

\section{Section I. Information for plant species collected}

The names and information for each individual species collected have been compiled (Table 2.1). The growth stages were differentiated during collections using the listed characteristics in the protocol (Table 2.2). The locations and months for each sample collected were recorded in Table 2.3 and Table 2.4. Results of wet chemistry analyses for each individual species have been provided in the form of raw means of nutritive values (Table 2.5- Table 2.8). Means for CP across all species and growth stages ranged from $2-17 \%$. Across all stages, mean values for NDF ranged from $60-80 \%$, with the exception of the Italian ryegrass and wild oats with lower values in the LV stage (Table 2.5), and filaree with lower values at all growth stages. For each plant species, NDF values were higher than those of ADF. Acid detergent fiber values ranged from 29$48 \%$ across all stages, with the exception of lower values found in Italian ryegrass at LV stage and in filaree at all stages (Table 2.5- Table 2.8).

\section{Section II. Annual and perennial grass chemical composition}

Descriptive means for nutrient content of annual and perennial grasses, at each growth stage are shown in Table 2.9. Based on the descriptive means, annuals demonstrate a 1-3\% higher level of CP at all four growth stages (Table 2.9). Annuals contained a $2 \%$ greater concentration of $\mathrm{CP}$ than perennials across all growth stages $(P \leq$ 0.05; Table 2.10). Perennials demonstrated a higher percentage of NDF and ADF than annuals, $10 \%$ and $5 \%$ higher, respectively $(P<0.01$; Table 2.10$)$. The composition of 
ADL, for both perennials and annuals, across all growth stages, was not different (Table 2.10). With percent ash corrected for, aNDFom was also higher in the perennials by $11 \%$ $(P<0.01$; Table 2.10). Dry matter, OM, and ash were similar for both growth types (Table 2.10). No stage and type interaction was identified for any of the nutrients. Broadleaf filaree was omitted from the statistical analysis.

\section{Section III. Chemical composition changes with grass maturity}

Independent of growth type, $\mathrm{NDF}, \mathrm{ADF}, \mathrm{ADL}$, and aNDFom concentration increased with maturity from the LV to the D stage $(P<0.01)$, whereas $\mathrm{CP}$ decreased by 9\% with maturity $(P<0.01)$. Neutral detergent fiber, ADF, ADL, and aNDFom increased by $13,12,1 \%$, and $16 \%$, respectively, with increasing maturity (i.e., LV to $\mathrm{D} ; P \leq 0.01$; Table 2.11). Dry matter content was not affected by maturity from LV to D stage $(P>$ $0.05)$, but $\mathrm{OM}$ increased by $3 \%$ while ash content decreased by $3 \%(P \leq 0.05$; Table 2.11). Broadleaf filaree was omitted from the statistical analysis.

\section{Section IV. Dry matter and organic matter digestibility of grasses}

Following the three in situ ruminal incubation periods, DMD and OMD of annuals differed between the 12 and 24-h periods, the 24 and 48-h periods, and the 12 and 48-h periods $(P \leq 0.05)$ (Table 2.12). Broadleaf filaree was omitted from the statistical analysis for in situ disappearance. No stage and time interaction was detected for DMD and OMD of grasses. 
Only within the 48-hr period did the DMD and OMD differ between the annuals and perennials $(P \leq 0.05)$ (Table 2.13). Digestibility of perennials and annuals following the 48 -hr period differed by $10 \%$, where annuals were more digestible than perennials (Table 2.13). Dry matter digestibility and OMD for both annuals and perennials were 7$10 \%$ at $12 \mathrm{~h}$ and $18-21 \%$ at $24 \mathrm{~h}$. At $48 \mathrm{~h}$, the DMD and OMD for annual grasses were $42 \%$ and $46 \%$, and for perennials they were $32 \%$ and $34 \%$. There were no significant differences in DMD and OMD between annuals and perennials at the 12 and 24-hr periods.

No interaction was identified between the two growth types at different growth stages for OMD. However, there was an interaction between growth type and growth stage for DMD, which differed between annuals and perennials at the LR and D stages $(P$ $\leq 0.05$; Table 2.14). In terms of DMD, annuals were $5 \%$ more digestible than perennials at the LR and D stage ( $P \leq 0.05$; Table 2.14). The DMD did not differ between annuals and perennials at LV and ER stages.

Dry matter digestibility values, across all stages, in order of LV to D, $26-21 \%$ for annuals, and $25-17 \%$ for perennials. The digestibility of perennial grasses decreased between stages LV, ER, and LR $(P \leq 0.05)$, but did not change between the LR and D stages $(P>0.05)$. Annual grasses did not significantly change in DMD following the ER stage. However, annual grasses decreased significantly in DMD from LV to ER $(P \leq$ 0.05; Table 2.15). 


\section{DISCUSSION}

\section{Section I. Chemical composition of grasses and forbs at different growth stages}

The primary objective of this experiment was to analyze and compare the initial chemical composition of annual and perennial plants at four stages of progressing maturity. The second objective was to test the in situ digestibility of annual and perennial grasses at each of these four stages. The initial nutrition composition results include one forb, broadleaf filaree, and nine grass species.

Broadleaf filaree was omitted from the statistical analysis for the purpose of producing the most accurate representation of annual grasses. Previous research has shown the forbs produced higher in vitro dry matter digestibility coefficients and greater mineral content than grasses (Hoehne et al., 1968). However, forbs constituted up to $50 \%$ of the DM content of esophageal contents from cattle grazing native range (Hoenhe et al., 1968), attesting to the importance that they have to beef cattle nutrition, an area that merits further exploration.

The LV stage of soft chess was unable to be collected due to the difficulty in differentiating between it and the LV stage of purple false brome. Soft chess at LR stage was not collected due to the brief transition time from ER stage to D stage. Previous literature has shown that percent crude fiber for soft chess averaged $28.58 \%$ for LV, 26.74 for ER, 29.84\% for LR, and 31.82\% for D (Hart and Guillbert, 1932; Gordon \& Sampson, 1939).

It is important to note that anecdotal evidence of the nutritional components for individual plant species, all annual grasses combined (not including broadleaf filaree), and perennial grasses have been reported. Some of the observed means for fiber content do not increase consistently with maturity, contrary to what might be expected. However, these observations are not entirely unusual. Wrysinski (1998) has reported ADF values for blue 
wildrye and creeping wildrye that are slightly higher in the ER stages (45.45 and 44.38) than in the LR stage (33.9 and 42.23). Several individual measurements of crude fiber for annual grasses, filaree, and bur clover, across 12 stages of maturity, were higher in earlier stages than in the preceding stages (George and Bell, 2001).

Sources of error that could have attributed to any oddities in the values that were observed may have to do with ADL analysis, drying methods, or sampling location. Hatfield and Fukushima (2005) found that the ADL procedure produced the lowest lignin values, whereas the permanganate lignin, also based on ADF, produced much higher values. While all values obtained from chemical analyses were corrected for $\% \mathrm{DM}$, some initial plant samples were dried, at $27^{\circ} \mathrm{C}$, rather than $80^{\circ} \mathrm{C}$, which is recommended for proper preservation and plant analysis (Kalra, 1998). Arzani et al. (2001) also sampled grasses from various sites and reported that location had a significant effect on forage quality.

\section{Section II. Growth stage and type significantly affect nutritive values of annual and perennial grasses}

To address the first objective of this research, the means of the nutritional components of annual and perennial grasses were compared through statistical analysis. As forages mature, the proportion of fiber typically increases and crude protein proportion decreases (NRC, 1996;

Sedivec et al., 1997; White and Wolf, 2009; Wrysinski et al., 1998). Sun et al. (2010) found that in the June harvest (beginning of the winter season in New Zealand) perennial ryegrass had a significantly lower $\mathrm{CP}$ content than that of Italian ryegrass and a ryegrass hybrid $(P<0.05)$. The August harvest of perennial ryegrass cultivars had higher observable means for $\mathrm{CP}$ content (225 $\mathrm{g} / \mathrm{kg} \mathrm{DM})$ than Italian ryegrass cultivars ( $181 \mathrm{~g} / \mathrm{kg} \mathrm{DM})$, but was not different from the Italian 
ryegrass and the hybrid cultivars $(P>0.05)$. No differences were found in ash concentrations of all three ryegrass types $(P>0.05)$. The June findings corroborate the evidence from this study that, across all growth stages, the perennial grasses studied were lower in CP than the annual grasses studied $(P \leq 0.05)$. In the current study, there was no interaction detected between growth stage and growth type, so only main effects were presented.

Across harvest dates, there was a difference $(P \leq 0.05)$ seen in the NDF content of perennial ryegrass (468 g/kg DM) and Italian ryegrass (414 g/kg; Sun et al., 2010). These findings were in line with those of the current study, in which the perennial grasses had a higher NDF content than the annual grasses $(P<0.01)$, across all growth stages. Besides the work of Sun et al. (2010), comparing annual and perennial ryegrass cultivars, there is undoubtedly a lack of research to address the nutritional differences in annual and perennial grasses, and, more specifically, the differences of the two growth types as they mature. This topic is understudied in the realm of rangeland grass species of California. Wrysinski et al (1998) has reported the nutritional composition of native perennial grasses of California at four growth stages, however no comparison to annual species was made.

A decline in ash content as all grasses matured was also observed in this study $(P \leq$ 0.05). Similarly, a majority of minerals tested for in grasses from five ranches in Wyoming declined as the grasses matured and weathered. Most notably, phosphorous, sulfur, and zinc declined with maturity. Calcium increased with maturity, but declined with weathering (Horn, 2012). Our results showed a decrease in ash (mineral content) as all plants matured $(P \leq 0.05)$. 


\section{Section III. Effects of ruminal incubation period, growth stages, and growth type on digestibility}

To address the second objective of this research, we calculated the disappearance of DM within the rumen as indicator of the digestible fiber fraction of a given sample. The resulting values of DM disappearance were compared statistically between annual and perennial grasses at the four growth stages. Digestibility of forage decreased with maturity (Arzani et al., 2004; Sun et al., 2010; Thamaraj et al., 2008), while cellulose increased, as a proportion of the plant, and the ratio of stems to leaves increased (Fahey and Berger, 1988).

This concept has also been demonstrated on ryegrass and fescue-based pastures in Victoria, Australia by Thamaraj et al. (2008). Their results showed that, in the winter months (early growth stages), NDF concentration was low, while CP, DMD, and ME were high. Adversely, in the summer months (late growth stages), NDF concentration increased while CP, DMD, and ME decreased. It was also reported by Bosman (1970) that, as the proportion of NDF and ADF content of grasses increased, the OMD decreased (as cited by Minson, 1990). Alternatively, as the CP content increased, the OMD increased (Minson and Kemp, 1961).

Weston (1985) ranked digestibility as high, medium, and low. As cell wall per kg of grass sample increased from 430 to 670, the digestibility ranking decreased. Sullivan (1964) and McLeod and Minson (1976), reported that a high ADL content of grasses resulted in a low DMD. Gustavsson \& Martinsson, (2004) used the indigestible fiber (IF) fraction of timothy hay (Phleum pretense L.) as an indicator of the cell wall concentration due to the fact that, across all the seasons and harvests, the IF increased exponentially with an increase in NDF concentration.

While these concepts are well understood and thoroughly researched, little research has been done to compare the digestibility of annual and perennial grasses. Sun et al. (2010) has 
compared both the nutritional and digestibility characteristics of annual and perennial grasses. When comparing the IF and the degradation rates of perennial ryegrass cultivars and annual ryegrass cultivars following in sacco digestion in dairy cows, Sun et al. (2010) observed differences $(P=0.06)$ in the degradation rates of the two growth types over $2,4,7,9,12,24$, and $72 \mathrm{~h}$ incubation periods. While they did not report the specific differences at each hour, the annual ryegrasses degraded noticeably faster $\left(0.196 \mathrm{~h}^{-1}\right)$ than did the perennial ryegrasses $(0.150$ $\mathrm{h}^{-1}$ ), but these observations were not significant.

Based on the findings above, perennial grasses may require a longer ruminating time. Weston (1985) matched ruminating time in h/kg DM with high, medium, and low digestibility rankings. A longer ruminating time of $11.1 \mathrm{~h}$ corresponded with the low ranking, whereas a $5.1 \mathrm{~h}$ was ranked high. Previous experiments by Mehrez and Ørskov, (1977) demonstrated the digestibility of barley in fiber bags in the rumen of sheep, over several incubation periods. Their results show a $70 \%$ disappearance in dry matter from the start time to the $12 \mathrm{~h}$ period, and only a $10 \%$ increase in dry matter disappearance from the $12 \mathrm{~h}$ to the $24 \mathrm{~h}$ incubation period. These results show that a majority of the barley sample was digested with the 12 and $24 \mathrm{~h}$ incubation periods. Results on the digestibility of grasses also showed significant increases in digestibility with increasing incubation time, but half of the DM disappearance (20\%) occurred within the 24$\mathrm{h}$ incubation period and the second half occurred between the 24 and 48 -h incubation periods ( > $20 \%)$.

No interaction was observed between growth stage and ruminal incubation time in this study. However, Fredrickson et al. (1993) have provided evidence of changes in organic matter digestibility of native blue grama (Boutelloua gracillis) in eight ruminally cannulated steers grazing native blue grama ranges in August, October, and November in New Mexico in 1987. 
The authors did not specify the stage of maturity at each month, but their objective was to address the effect of phenology on ruminal digestion, assuming that plants increased in maturity as the months progressed. They reported that at incubation periods 3, 6, 9, and $12 \mathrm{~h}$, percent NDF disappearance of native blue grama was lower in the October forage samples than the November forage samples $(P<0.05)$. The same was true between the August and November samples. At the $48 \mathrm{~h}$ period, the $\%$ NDF disappearance of forage samples from August was higher than that of samples from November $(P<0.05$; Frederickson et al., 1993).

These study results do not include the proportions of the specific chemical components remaining in the undigested portion of the $48 \mathrm{~h}$ samples. Knowing this information would provide further insight as to the type of particle material that was digested in the rumen. Huntanen et al. (2008) compiled the work of several authors who have found that large particles and particles with a higher proportion of digestible neutral detergent fiber (DNDF) were selectively retained in the rumen, whereas particles consisting of indigestible neutral detergent fiber (INDF) had a higher probability of escaping from the rumen. This conclusion was drawn based on evidence that the passage rate of INDF was faster than DNDF (Huntanen et al., 2008).

Being that the current study did not test for the digestibility of specific nutrients in annual and perennial grasses, this leaves potential for future research in this area of study. In terms of CP digestibility, RUP from forages is often only 10-40\% of CP (NRC, 1996; NRC, 2001). Mehrez and Ørskov, (1977) observed that the resulting crude protein digestibility was similar to that of DMD. Both increased steadily for up to 12 hours of ruminal incubation. From the $12 \mathrm{~h}$ incubation period to the $24 \mathrm{~h}$ incubation, both DMD and $\mathrm{N}$ digestibility began to plateau. Elliot et al., (1961) reported that the digestibility of $\mathrm{CP}$ of grasses decreased by $70 \mathrm{~g} / \mathrm{kg}$ as grasses matured over a period of $28 \mathrm{wk}$. The greatest decrease was seen between 12 and $28 \mathrm{wk}$. To see if 
these reports of DMD can be applied to California annual and perennial grasses, further investigation will need to be done.

\section{Section IV. Improving perennial digestibility}

Phillips et al., 2009 utilized highly domesticated breeds to compare apparent digestibility. The three cool-season perennial varieties, Harusakae (Festuca pratensis), Jessup (Festuca arndinacea), and Nanyro (Festuca arundinacea) were compared to winter wheat (var. Pioneer 2174). The perennial, Nanyro, contained a greater concentration of $\mathrm{N}(P<0.05)$ and lesser concentration of NDF and ADF as a percentage of DM $(P>0.05)$ than all the other species. Despite this, the hays with significantly higher NDF and ADF fractions, produced higher NDF and ADF digestibility coefficients. The initial DM concentrations of all the hays were similar, as were those of the annuals and perennials in the current studies, but the DMD of the Nanyro hay was the lowest, which seems odd when compared to our findings that showed that plants containing lower fiber concentrations had a greater digestibility. Even though the winter wheat, an annual, had a lesser amount of NDF and ADF and greater amount of $\mathrm{N}$ than the perennials, Jessup and Harusakae, it was significantly less digestible than Jessup. Philips et al. (2009) revealed the possibility of breeding perennial grasses to retain drought and insect tolerant characteristics, but also to improve digestibility.

In the current study, several different plant species containing a variety of chemical compositions were incubated within the same rumen, simultaneously, which is similar to what might be found in the rumen contents of cattle grazing rangeland. McCal, (1940) compared the coefficients of apparent DMD between a pure stand of bluebunch wheatgrass (Agropyron spicatum) and mixture consisting of a majority bluebunch wheatgrass and $10 \%$ other forages. 
The mixture resulted in an $11.5 \%$ higher coefficient for DMD than that of the pure stand. The digestibility of the range mixture was to an even greater extent with the inclusion of linseed cake and barely to the ration. These findings support that a diversity of species in a pasture might improve the digestibility of perennial grasses.

\section{Section V. Managing for differences between annual and perennial-dominated}

\section{pastures}

Gustavsson and Martinsson (2004) attempted to find the stage of growth that matches with the optimal digestibility of timothy hay. Of the morphological changes measured, the greatest changed was in stem growth, which occurred closest in time with optimal digestibility. This suggests that stem growth is a good indicator of optimal digestibility. The current study results of the changes between growth stages within annual and perennial grasses are consistent with this conclusion. There was a significant decline in digestibility between the LV and ER stages, within the annual grasses, $(P \leq 0.05)$, but DMD remained rather constant throughout the rest of the growth stages. This decline in DMD continued in perennials up to the LR stage ( $P \leq$ 0.05). The DMD of perennial grasses at the LR and D stages did not differ likely due to the inherent nature of perennials to go through a dormancy period rather than to die completely, unlike the annual grasses (Chiariello, 1989; Reever Morghan et al., 2007).

These results may indicate that annuals are a more reliable feed source in the summer months. Perennials are better to graze in the LV stage, not only because of their higher digestibility in that stage, as the current study indicated, but also due to the fact that they respond well to early, short-duration grazing (Jones and Love, 1945) and are less prone to damage while they contain a higher proportion of meristematic tissue (Manske, 1999). 
According to the time at which annuals were collected in the LV stage for this study, grazing during the first couple months of the year should focus on the pastures consisting of a majority annual grasses, as they were rapidly germinating and were the most digestible during this time. Ranchers should be cautioned to avoid urea toxicity while grazing cattle on large amounts of vegetative forage as it may contain higher amounts of CP and lower amounts of energy. Ruminant animals can be monitored via coloration of mucosae and the proportion of carbohydrates in the diet should be increased if urea toxicity appears to be a potential issue (Nicholls and Miles, 1980; Rogers, 1999).

Perennials do not produce a substantial amount of biomass until after most of the annuals have gone through the LV stage. Jones and Love (1945) were some of the first to research the improvement of rangelands in California and have also suggested that grazing of perennial grasses occur once in the early spring when these grasses are least vulnerable. Given the proper conditions, and while in the vegetative stage, grazing can be beneficial to stimulating growth in the remaining parts of the plant (Briske and Richards, 1995; White and Wolf, 2009). Grazing also has a noticeable effect on the nutritive value of grass plants (Manske, 1999; Jackson and Bartolome, 2007). Defoliated individuals have demonstrated a lesser degree of lignification compared to non-defoliated counterparts (Van Soest, 1994). These observations provide evidence that managed defoliation can improve the digestibility of grasses.

Due to the sensitivity of perennials to grazing (Jones and Love, 1945), these species should be monitored carefully and grazing of them should be kept to a minimum if the goal is to reestablish them within a pasture. However, of the perennial grasses, purple needlegrass has proven to be the most resistant to grazing (Bartolme et al., 2004; Hatch et al., 1999; Lulow et al., 
2008). Based on field observations during the sample collections for this study, purple needlegrass produced the most biomass of the needlegrasses.

Depending on the location of perennial grasses, such as creeping wildrye and blue wildrye, as observed in this study, they may come into LV stage in the summer (Laude, 1953; Reever Morghan et al., 2007), as the annuals are dying and have low DMD (Minson, 1990). Taking advantage of this timing by grazing perennials at LV stage in the summer, is an option, but it is also important to realize that the factors that allow perennial grasses to retain living tissue via drought tolerance (Garnier, 1992) may also be the same factors that could cause a plant to be less palatable (Provenza et al., 2003). However, several authors have addressed the importance and successes of training livestock to consume less palatable plants, which comes with introducing a diversity of plants into their diets (Meuret and Provenza, 2015; Provenza et al., 2015).

When the only available grasses are in the D stage, typically late summer or fall in California, the $\mathrm{CP}$ content may not be sufficient to meet the needs of yearling calves or lactating female cattle. Therefore, cattle should be provided supplementation in the form of protein concentrates such as cottonseed cake or meal (Jones and Love, 1945; Hersom, 2008), safflower, and oil meal (George et al., 2001b) or urea $\left(\mathrm{CH}_{4} \mathrm{~N}_{2} \mathrm{O}\right)$ (George et al., 2001b; Sewell, 1993) in order to offset nutrient deficiencies and maintain adequate animal performance (Waterman et al., 2014). In fact, several studies such as those from Bohnert et al. (2002a, b, c) and Moore et al. (1999) have produced positive results in terms of improving animal performance by increasing the frequency of feeding protein supplements from two to seven d/wk, which coincided with a linear increase in OMD and NDF digestibility (Bohnert et al., 2002a, b, c). This is a method that has been coined as nutrient synchrony. 
Grazing with the intent of improving animal performance and ecological health demands an intimate knowledge of the landscape. The observations from previous literature and the present research may help to guide the timing of grazing individual species. Henneman et al. (2014) have suggested timing grazing in alignment with the proper stage of the annual species to allow native perennials a chance to recover. Ranchers and land managers have to be attuned to the historic and current conditions of their land in response to the environmental conditions. Knowledge of the nutritive values and digestibility of annual and perennial plants at particular growth stages can assist in planning for consistent provision of forages with optimal digestibility to the grazing animal. 


\section{IMPLICATIONS}

As forages found on California ranges are an integral part of livestock production in the state, it is important to establish an understanding of the nutritional value of the forage itself and in relation to the animal consuming it. This study measured the nutritional composition of native perennial plants and non-native annual plants that are commonly found on California ranges. No definitive comparisons between individual species could be made from these values however, because of a small sample size. This leaves room for further study on individual plant species of the San Luis Obispo county area in California. However, the main objectives of this study were to analyze the characteristic nutritional and digestibility differences between annual and perennial plants at four growth stages.

Our findings are in line with our predictions and provide sound evidence on the differences in protein and fiber composition, and dry matter digestibility between annual and perennial grasses rather than the many theories that have been utilized in the past. As predicted, fiber composition increased and crude protein composition decreased as plants matured. Annuals were more digestible than perennials, but only during the stages which, during this study, occurred in May through August. During the early stages of growth, which occurred between January and April, for most species, the dry matter digestibility of both annuals and perennials were similar. Before utilizing this information for the development of grazing management plans, it is important to note that each species matured at different rates. The rate of maturity will also differ according to location. Highly digestible forages are likely to be found in locations composed of mostly annual grasses, especially in the summer. Both perennial and annual grasses can serve as good a 
source of digestible forage in the spring months. For the improved establishment of perennials, they should be grazed less often than annuals. 
Table 2.1

Corresponding codes for grass and forb species

\begin{tabular}{llll}
\hline Code $^{1}$ & Species & Common Name & Growth Type \\
\hline AVENA & Avena spp. & Wild oats & Annual \\
BRDI2 & Brachypodium distachyon & Purple false brome & Annual \\
BRHO2 & Bromus hordeaceous & Soft chess & Annual \\
ELGL & Elymus glaucus & Blue wildrye & Perennial \\
ERBO & Erodium botrys & Broadleaf filaree & Annual \\
LETR5 & Leymus tritichoides & Creeping wildrye & Perennial \\
LOMU & Lolium multiflorum & Italian ryegrass & Perennial \\
MECA2 & Melica spp. & California melic & Perennial \\
NALE2 & Nasella lepida & Foothill needlegrass & Perennial \\
NAPU4 & Nasella pulchra & Purple needlegrass & Perennial \\
\hline
\end{tabular}

${ }^{1}$ Codes designated by the USDA 


\section{Table 2.2}

Protocol for determination of the four growth stages of grasses

\begin{tabular}{ll}
\hline Stage & Description $^{1}$ \\
\hline Late vegetative & $\begin{array}{l}\text { Internode lengthening to boot stage. The inflorescence } \\
\text { has not emerged yet. }\end{array}$
\end{tabular}

Early reproductive Emergence of flower to milk stage. Seed is still soft, not fully developed. Anthers are still on the majority of the spikelets.

Late Reproductive Seeds fall off easily when rubbed, or some have already been cast from the inflorescence. Annuals have practically lost all pigmentation. Perennials may be more pigmented, but still losing seed.

Dry Includes growth from current year, not residual dry matter. Perennials may have some green/pigmentation remaining in the bottom 4-6 inches of the tiller.

Annuals are completely dry like straw at this point.

${ }^{1}$ Adapted from Laca (2015)

* Similar protocol were utilized for Broadleaf filaree 


\section{Table 2.3}

Plant species collected at various sites in San Luis Obispo, California, from May 2016 to July 2016 and January 2017 to April 2017

\begin{tabular}{|c|c|c|c|c|}
\hline Site & Species & Growth Stage & Growth Type & Origin* \\
\hline \multicolumn{5}{|l|}{ Walter's Ranch } \\
\hline Wild oats & Avena spp. & $\mathrm{D}$ & Annual grass & non-native invasive \\
\hline Creeping wildrye & Leymus tritichoides & LR, D & Perennial grass & native \\
\hline \multicolumn{5}{|l|}{ Poly Canyon } \\
\hline Wild oats & Avena spp. & LR & Annual grass & non-native invasive \\
\hline Soft chess & Bromus hordeaceus & $\mathrm{ER}, \mathrm{D}$ & Annual grass & non-native invasive \\
\hline California melic & Melica californica & ER, LR, D & Perennial grass & native \\
\hline Foothill needlegrass & Nasella lepida & $\mathrm{LV}, \mathrm{ER}$ & Perennial grass & native \\
\hline \multicolumn{5}{|l|}{ Irish Hills } \\
\hline Blue wildrye & Elymus glaucus & $\begin{array}{l}\text { LV, ER, LR, } \\
\text { D }\end{array}$ & Perennial grass & native \\
\hline Annual ryegrass & Lolium multiflorum & $\mathrm{LR}, \mathrm{D}$ & Annual grass & non-native invasive \\
\hline \multicolumn{5}{|l|}{ Camp San Luis } \\
\hline False brome & $\begin{array}{l}\text { Brachypodium } \\
\text { distachyon }\end{array}$ & $\mathrm{LV}$ & Annual grass & non-native invasive \\
\hline Redstem filaree & Erodium cicutarium & $\mathrm{LR}, \mathrm{D}$ & Annual forb & non-native invasive \\
\hline Foothill needlegrass & Nasella lepida & ER, LR, D & Perennial grass & native \\
\hline Purple needlegrass & Nasella pulchra & $\mathrm{LR}, \mathrm{D}$ & Perennial grass & native \\
\hline
\end{tabular}

*Origin and life cycle obtained from CalFlora online database (CalFlora, 2017) 


\section{Table 2.4}

Months and year of collection, USDA species abbreviation (USDA-NRCS, 2017), and growth stage of plant species were collected from San Luis Obispo, CA. Growth stage indicates when grasses and filaree were available and collected.

\begin{tabular}{|c|c|c|c|}
\hline Year & Month & Species & Growth Stage \\
\hline \multirow[t]{25}{*}{2016} & May & AVENA & LR \\
\hline & & AVENA & $\mathrm{D}$ \\
\hline & & BRHO2 & $\mathrm{D}$ \\
\hline & & ELGL & LV \\
\hline & & ELGL & ER \\
\hline & & ELGL & LR \\
\hline & & ERBO & LR \\
\hline & & LETR5 & LV \\
\hline & & LETR5 & ER \\
\hline & & LOMU & LR \\
\hline & & MECA2 & LR \\
\hline & & NALE2 & LR \\
\hline & & NAPU4 & LR \\
\hline & June & ELGL & $\mathrm{D}$ \\
\hline & & LETR5 & LR \\
\hline & & LOMU & D \\
\hline & & LOMU & D \\
\hline & & NALE2 & D \\
\hline & & NALE2 & $\mathrm{D}$ \\
\hline & July & ERBO & $\mathrm{D}$ \\
\hline & & MECA2 & D \\
\hline & & MECA2 & D \\
\hline & & NAPU4 & D \\
\hline & & NAPU4 & $\mathrm{D}$ \\
\hline & August & LETR5 & D \\
\hline \multirow[t]{14}{*}{2017} & January & AVENA & $\mathrm{LV}$ \\
\hline & February & AVENA & ER \\
\hline & & ERBO & LV \\
\hline & & LOMU & LV \\
\hline & & MECA2 & LV \\
\hline & & NAPU4 & LV \\
\hline & & NAPU4 & ER \\
\hline & Feb-Mar & NALE2 & LV \\
\hline & March & BRDI2 & LV \\
\hline & & ERBO & ER \\
\hline & & LOMU & ER \\
\hline & & MECA2 & ER \\
\hline & Mar-Apr & NALE2 & ER \\
\hline & April & BRHO2 & ER \\
\hline
\end{tabular}


Table 2.5

Chemical composition (\%DM) of plant species sampled at late vegetative stage.

\begin{tabular}{|c|c|c|c|c|c|c|c|c|}
\hline \multicolumn{9}{|c|}{ LATE VEGETATIVE } \\
\hline \multicolumn{9}{|l|}{ Plant Type } \\
\hline Species $^{1}$ & $\mathrm{CP}^{2}$ & $\mathrm{NDF}^{3}$ & $\mathrm{ADF}^{4}$ & $\mathrm{ADL}^{5}$ & $\mathrm{DM}^{6}$ & $\mathrm{OM}^{7}$ & Ash & aNDFom $^{8}$ \\
\hline \multicolumn{9}{|l|}{ Grass } \\
\hline AVENA & 15.90 & 52.45 & 29.27 & 7.79 & 92.63 & 86.78 & 13.22 & 39.23 \\
\hline BRDI2 & 11.09 & 64.81 & 34.31 & 9.20 & 90.82 & 88.07 & 11.93 & 52.88 \\
\hline $\mathrm{BRHO}^{9}$ & - & - & - & - & - & - & - & - \\
\hline ELGL & 11.84 & 62.80 & 32.48 & 8.40 & 92.26 & 88.85 & 11.15 & 51.65 \\
\hline LETR5 & 7.61 & 75.21 & 41.22 & 8.32 & 91.87 & 95.12 & 4.88 & 70.33 \\
\hline LOMU & 17.37 & 52.29 & 25.38 & 6.86 & 90.82 & 85.98 & 14.02 & 38.27 \\
\hline MECA2 & 16.59 & 68.25 & 36.67 & 8.14 & 90.19 & 87.55 & 12.45 & 55.81 \\
\hline NALE2 & 12.50 & 65.77 & 31.49 & 8.20 & 91.35 & 88.79 & 11.21 & 54.56 \\
\hline NAPU4 & 12.03 & 68.49 & 31.96 & 7.49 & 92.05 & 90.59 & 9.41 & 59.08 \\
\hline \multicolumn{9}{|l|}{ Forb } \\
\hline ERBO & 15.61 & 24.26 & 17.02 & 21.30 & 85.84 & 90.06 & 9.94 & 14.31 \\
\hline $\begin{array}{l}{ }^{1} \text { Codes designat } \\
{ }^{2} \text { Crude protein }( \\
3{ }^{3} \text { Neutral deterge } \\
{ }^{4} \text { Acid detergent } \\
{ }^{5} \text { Acid detergent } \\
{ }^{6} \text { Dry matter }(\%) \\
{ }^{7} \text { Organic matter } \\
{ }^{8} \text { Ash-corrected } \\
{ }^{9} \text { Not collected, }\end{array}$ & $\begin{array}{l}\text { y the } L \\
\text { M) } \\
\text { iber }(\% \\
\text { r }(\% \mathrm{DI} \\
\text { in }(\% \mathrm{D}\end{array}$ & corresp & plant s & & & & & \\
\hline
\end{tabular}


Table 2.6

Chemical composition (\%DM) of plant species sampled at early reproductive stage.

\begin{tabular}{|c|c|c|c|c|c|c|c|c|}
\hline \multicolumn{9}{|c|}{ EARLY REPRODUCTIVE } \\
\hline \multicolumn{9}{|c|}{ Plant Type } \\
\hline Species $^{1}$ & $\mathrm{CP}^{2}$ & $\mathrm{NDF}^{3}$ & $\mathrm{ADF}^{4}$ & $\mathrm{ADL}^{5}$ & $\mathrm{DM}^{6}$ & $\mathrm{OM}^{7}$ & Ash & aNDFom $^{8}$ \\
\hline \multicolumn{9}{|l|}{ Grass } \\
\hline AVENA & 9.05 & 70.56 & 40.96 & 6.56 & 90.61 & 92.25 & 7.75 & 62.81 \\
\hline $\mathrm{BRDI}^{9}$ & - & - & - & - & - & - & - & - \\
\hline BRHO2 & 8.34 & 63.16 & 33.93 & 6.82 & 91.65 & 92.82 & 7.18 & 55.99 \\
\hline ELGL & 8.29 & 73.48 & 41.54 & 8.37 & 91.64 & 92.75 & 7.25 & 66.24 \\
\hline LETR5 & 6.89 & 76.23 & 43.13 & 9.05 & 92.34 & 95.48 & 4.52 & 71.71 \\
\hline LOMU & 8.74 & 60.95 & 34.03 & 7.18 & 91.36 & 89.59 & 10.41 & 50.54 \\
\hline MECA2 & 10.39 & 71.84 & 39.33 & 7.30 & 90.67 & 90.91 & 9.09 & 62.75 \\
\hline NALE2 & 8.64 & 74.22 & 39.58 & 7.39 & 93.12 & 91.94 & 8.06 & 66.16 \\
\hline NAPU4 & 9.80 & 72.96 & 37.93 & 6.48 & 93.03 & 92.48 & 7.52 & 65.44 \\
\hline \multicolumn{9}{|l|}{ Forb } \\
\hline ERBO & 16.48 & 31.17 & 23.05 & 21.85 & 86.27 & 89.07 & 10.93 & 20.23 \\
\hline
\end{tabular}

${ }^{1}$ Codes designated by the USDA, correspond to plant species

${ }^{2}$ Crude protein (\%DM)

${ }^{3}$ Neutral detergent fiber $(\% \mathrm{DM})$

${ }^{4}$ Acid detergent fiber (\%DM)

${ }^{5}$ Acid detergent lignin (\%DM)

${ }^{6}$ Dry matter (\%)

${ }^{7}$ Organic matter (\%)

${ }^{8}$ Ash-corrected neutral detergent fiber $(\% \mathrm{OM})$ 
${ }^{9}$ Not collected 
Table 2.7

Chemical composition (\%DM) of plant species sampled at late reproductive stage.

\begin{tabular}{|c|c|c|c|c|c|c|c|c|}
\hline \multicolumn{9}{|c|}{ LATE REPRODUCTIVE } \\
\hline \multicolumn{9}{|l|}{ Plant Type } \\
\hline Species $^{1}$ & $\mathrm{CP}^{2}$ & $\mathrm{NDF}^{3}$ & $\mathrm{ADF}^{4}$ & $\mathrm{ADL}^{5}$ & $\mathrm{DM}^{6}$ & $\mathrm{OM}^{7}$ & Ash & aNDFom $^{8}$ \\
\hline \multicolumn{9}{|l|}{ Grass } \\
\hline AVENA & 10.01 & 64.54 & 38.07 & 8.25 & 92.28 & 90.39 & 9.61 & 54.93 \\
\hline $\mathrm{BRDI}^{9}$ & - & - & - & - & - & - & - & - \\
\hline $\mathrm{BRHO}_{2}^{9}$ & - & - & - & - & - & - & - & - \\
\hline ELGL & 6.32 & 78.66 & 44.33 & 9.11 & 89.74 & 90.37 & 9.63 & 69.03 \\
\hline LETR5 & 4.87 & 77.87 & 44.93 & 10.17 & 92.27 & 95.01 & 4.99 & 72.88 \\
\hline LOMU & 7.19 & 58.25 & 30.01 & 9.75 & 92.92 & 91.92 & 8.08 & 50.17 \\
\hline MECA2 & 5.77 & 72.35 & 38.93 & 8.91 & 91.62 & 89.84 & 10.16 & 62.19 \\
\hline NALE2 & 5.98 & 72.82 & 39.63 & 12.01 & 92.47 & 88.78 & 11.22 & 61.61 \\
\hline NAPU4 & 4.89 & 77.74 & 42.32 & 8.81 & 91.55 & 93.28 & 6.72 & 71.02 \\
\hline \multicolumn{9}{|l|}{ Forb } \\
\hline ERBO & 4.98 & 47.32 & 35.01 & 13.70 & 92.12 & 92.41 & 7.59 & 39.72 \\
\hline
\end{tabular}

${ }^{1}$ Codes designated by the USDA, correspond to plant species

${ }^{2}$ Crude protein (\%DM)

${ }^{3}$ Neutral detergent fiber (\%DM)

${ }^{4}$ Acid detergent fiber $(\% \mathrm{DM})$

${ }^{5}$ Acid detergent lignin (\%DM)

${ }^{6}$ Dry matter (\%)

${ }^{7}$ Organic matter $(\%)$

${ }^{8}$ Ash-corrected neutral detergent fiber (\%OM) 
${ }^{9}$ Not collected 


\section{Table 2.8}

Chemical composition (\%DM) of plant species sampled at dry stage.

\begin{tabular}{|c|c|c|c|c|c|c|c|c|}
\hline \multicolumn{9}{|l|}{$\overline{D R Y}$} \\
\hline \multicolumn{9}{|l|}{ Plant Type } \\
\hline Species $^{1}$ & $\mathrm{CP}^{2}$ & $\mathrm{NDF}^{3}$ & $\mathrm{ADF}^{4}$ & $\mathrm{ADL}^{5}$ & $\mathrm{DM}^{6}$ & $\mathrm{OM}^{7}$ & Ash & aNDFom $^{8}$ \\
\hline \multicolumn{9}{|l|}{ Grass } \\
\hline AVENA & 6.35 & 71.64 & 39.96 & 8.19 & 91.70 & 90.87 & 9.13 & 62.50 \\
\hline $\mathrm{BRDI}^{9}{ }^{9}$ & - & - & - & - & - & - & - & - \\
\hline $\mathrm{BRHO}^{9}{ }^{9}$ & 3.78 & 78.93 & 45.14 & 7.77 & 91.35 & 94.17 & 5.83 & 73.10 \\
\hline ELGL & 3.15 & 80.41 & 48.33 & 9.94 & 92.87 & 93.94 & 6.06 & 74.35 \\
\hline LETR5 & 5.05 & 77.97 & 46.55 & 11.46 & 92.19 & 94.84 & 5.16 & 72.81 \\
\hline LOMU & 5.14 & 70.98 & 43.10 & 9.74 & 91.54 & 89.65 & 10.35 & 60.62 \\
\hline MECA2 & 3.76 & 73.50 & 39.79 & 9.70 & 92.46 & 88.00 & 12.00 & 61.49 \\
\hline NALE2 & 3.60 & 76.82 & 42.70 & 8.44 & 91.79 & 89.21 & 10.79 & 66.02 \\
\hline NAPU4 & 1.77 & 83.78 & 49.48 & 8.34 & 92.20 & 94.16 & 5.84 & 77.94 \\
\hline \multicolumn{9}{|l|}{ Forb } \\
\hline ERBO & 4.32 & 52.75 & 38.59 & 14.49 & 91.20 & 89.94 & 10.06 & 42.69 \\
\hline $\begin{array}{l}{ }^{1} \text { Codes designate } \\
{ }^{2} \text { Crude protein }\left({ }^{9}\right. \\
{ }^{3} \text { Neutral deterger } \\
{ }^{4} \text { Acid detergent } \mathrm{f} \\
{ }^{5} \text { Acid detergent } 1 \\
{ }^{6} \text { Dry matter }(\%) \\
{ }^{7} \text { Organic matter } \\
{ }^{8} \text { Ash-corrected n } \\
{ }^{9} \text { Not collected }\end{array}$ & $\begin{array}{l}y \text { the U } \\
\text { M) } \\
\text { ber }(\% \\
(\% \mathrm{DN} \\
\text { n }(\% \mathrm{D}\end{array}$ & corresp & plant $\mathrm{s}$ & & & & & \\
\hline
\end{tabular}




\section{Table 2.9}

Descriptive means of nutritive values $(\% \mathrm{DM})$ for grasses $^{1}$ collected at all four stages of growth ${ }^{2}$.

\begin{tabular}{|c|c|c|c|c|c|c|c|c|}
\hline $\begin{array}{l}\text { Stage } \\
\text { Life-form }\end{array}$ & $\mathrm{CP}^{3}$ & $\mathrm{NDF}^{4}$ & $\mathrm{ADF}^{5}$ & $\mathrm{ADL}^{6}$ & $\mathrm{DM}^{7}$ & $\mathrm{OM}^{8}$ & Ash & aNDFom $^{9}$ \\
\hline \multicolumn{9}{|l|}{ Late vegetative } \\
\hline annual & 14.79 & 56.51 & 29.65 & 7.95 & 91.42 & 86.95 & 13.05 & 43.46 \\
\hline perennial & 12.11 & 68.11 & 34.77 & 8.11 & 91.55 & 90.18 & 9.82 & 58.29 \\
\hline \multicolumn{9}{|c|}{ Early reproductive } \\
\hline annual & 8.71 & 64.89 & 36.31 & 6.85 & 91.21 & 91.56 & 8.44 & 56.44 \\
\hline perennial & 8.80 & 73.75 & 40.30 & 7.72 & 92.16 & 92.71 & 7.29 & 66.46 \\
\hline \multicolumn{9}{|c|}{ Late reproductive } \\
\hline annual & 8.60 & 61.39 & 34.04 & 9.00 & 92.60 & 91.16 & 8.84 & 52.55 \\
\hline perennial & 5.57 & 75.89 & 42.03 & 9.80 & 91.53 & 91.46 & 8.54 & 67.35 \\
\hline \multicolumn{9}{|l|}{ Dry } \\
\hline annual & 5.09 & 73.85 & 42.73 & 8.56 & 91.53 & 91.56 & 8.44 & 65.41 \\
\hline perennial & 3.47 & 78.50 & 45.37 & 9.58 & 92.30 & 92.03 & 7.97 & 70.53 \\
\hline
\end{tabular}

${ }^{1}$ Does not include ERBO

${ }^{2}$ Each of the four stages were determined using defining characteristics of maturity level

${ }^{3}$ Crude protein $(\% \mathrm{DM})$

${ }^{4}$ Neutral detergent fiber $(\% \mathrm{DM})$

${ }^{5}$ Acid detergent fiber $(\% \mathrm{DM})$

${ }^{6}$ Acid detergent lignin $(\% \mathrm{DM})$

${ }^{7}$ Dry matter (\%) 
${ }^{8}$ Organic matter (\%)

${ }^{9}$ Ash-corrected neutral detergent fiber (\%DM) 


\section{Table 2.10}

Differences in means of nutritive values for all grasses grouped by growth type, across four stages of growth ${ }^{1}$.

\begin{tabular}{|c|c|c|c|c|}
\hline \multirow[b]{2}{*}{ Nutrient (\%DM) } & \multicolumn{2}{|c|}{ Growth Type } & \multirow[b]{2}{*}{$\mathrm{SE}^{2}$} & \multirow[b]{2}{*}{$P>\mathrm{F}$} \\
\hline & Annual & Perennial & & \\
\hline $\mathrm{CP}^{3}$ & 9.22 & 7.49 & 0.58 & $<0.05$ \\
\hline $\mathrm{NDF}^{4}$ & 64.45 & 74.06 & 1.32 & $<0.01$ \\
\hline $\mathrm{ADF}^{5}$ & 35.88 & 40.62 & 1.07 & $<0.01$ \\
\hline $\mathrm{ADL}^{6}$ & 8.10 & 8.80 & 0.30 & 0.07 \\
\hline $\mathrm{DM}^{7}$ & 91.61 & 91.88 & 0.26 & 0.40 \\
\hline $\mathrm{OM}^{8}$ & 90.24 & 91.60 & 0.71 & 0.14 \\
\hline Ash & 9.76 & 8.40 & 0.71 & 0.14 \\
\hline ANDFom $^{9}$ & 54.69 & 65.65 & 1.84 & $<0.01$ \\
\hline
\end{tabular}

${ }^{1}$ Each of the four stages were determined using defining characteristics of maturity level ${ }^{2}$ Standard error of the LSMeans

${ }^{3}$ Crude protein $(\% \mathrm{DM})$

${ }^{4}$ Neutral detergent fiber $(\% \mathrm{DM})$

${ }^{5}$ Acid detergent fiber $(\% \mathrm{DM})$

${ }^{6}$ Acid detergent lignin $(\% \mathrm{DM})$

${ }^{7}$ Dry matter (\%)

${ }^{8}$ Organic matter $(\%)$

${ }^{9}$ Ash-corrected neutral detergent fiber (\%DM) 
Table 2.11

Differences in means of nutritive values of all grasses grouped by stage of growth, across annual and perennial grasses.

\begin{tabular}{|c|c|c|c|c|c|c|}
\hline \multirow[b]{2}{*}{ Nutrient } & \multicolumn{4}{|c|}{ Growth Stage $^{1}$} & \multicolumn{2}{|c|}{ p-value } \\
\hline & $\mathrm{LV}$ & ER & LR & $\mathrm{D}$ & $\mathrm{SE}^{2}$ & Linear effect \\
\hline $\mathrm{CP}^{3}$ & 13.33 & 8.99 & 6.81 & 4.29 & 0.74 & $<0.01$ \\
\hline $\mathrm{NDF}^{4}$ & 62.56 & 69.22 & 69.69 & 75.55 & 1.68 & $<0.01$ \\
\hline $\mathrm{ADF}^{5}$ & 32.26 & 38.21 & 38.73 & 43.79 & 1.36 & $<0.01$ \\
\hline $\mathrm{ADL}^{6}$ & 7.96 & 7.31 & 9.42 & 9.11 & 0.38 & $<0.01$ \\
\hline $\mathrm{DM}^{7}$ & 91.47 & 91.77 & 91.78 & 91.98 & 0.33 & 0.27 \\
\hline $\mathrm{OM}^{8}$ & 88.80 & 92.11 & 91.08 & 91.68 & 0.91 & 0.05 \\
\hline Ash & 11.20 & 7.89 & 8.92 & 8.32 & 0.91 & 0.05 \\
\hline aNDFom $^{9}$ & 51.36 & 61.33 & 60.77 & 67.24 & 2.35 & $<0.01$ \\
\hline
\end{tabular}

${ }^{1} \mathrm{LV}=$ late vegetative, $\mathrm{ER}=$ early reproductive, $\mathrm{LR}=$ late reproductive, $\mathrm{D}=$ dry.

${ }^{2}$ Standard error of the LSMeans

${ }^{3}$ Crude protein $(\% \mathrm{DM})$

${ }^{4}$ Neutral detergent fiber $(\% \mathrm{DM})$

${ }^{5}$ Acid detergent fiber (\%DM)

${ }^{6}$ Acid detergent lignin (\%DM)

${ }^{7}$ Dry matter (\%)

${ }^{8}$ Organic matter (\%)

${ }^{9}$ Ash-corrected neutral detergent fiber (\%DM) 
Table 2.12

Dry matter digestibility (\%DMD) and organic matter digestibility (\%OMD) differences within annual and perennial grass species, after three in situ ruminal incubation periods (h).

\begin{tabular}{rcccc}
\hline & \multicolumn{3}{c}{ Period } & \multirow{2}{*}{ SE $^{1}$} \\
\cline { 2 - 4 } Growth Type & $12 \mathrm{~h}$ & $24 \mathrm{~h}$ & $48 \mathrm{~h}$ & 1.71 \\
\%DMD & & & & \\
Annual & $7.05^{\mathrm{a}}$ & $19.11^{\mathrm{b}}$ & $41.77^{\mathrm{c}}$ & \\
Perennial & $8.62^{\mathrm{a}}$ & $18.07^{\mathrm{b}}$ & $31.51^{\mathrm{c}}$ & \\
\%OMD & & & 1.98 \\
Annual & $8.44^{\mathrm{a}}$ & & & \\
Perennial & $10.05^{\mathrm{a}}$ & $21.12^{\mathrm{b}}$ & $45.57^{\mathrm{c}}$ & 1.26 \\
\hline
\end{tabular}

${ }^{1}$ Standard error of the LSMeans

${ }^{\mathrm{a}-\mathrm{c}}$ Means within a row with different subscripts differ, $P \leq 0.05$ 
Table 2.13

Dry matter digestibility (\%DMD) and organic matter digestibility (\%OMD) differences between grass growth types after three in situ ruminal incubation periods (h).

\begin{tabular}{lcccc}
\hline & \multicolumn{3}{c}{ Growth Type } & \\
\cline { 3 - 4 } & Period & Annual & Perennial & SE $^{1}$ \\
\hline \%DMD & & & 8.62 & 1.63 \\
& $12 \mathrm{~h}$ & 7.05 & 18.07 & 1.69 \\
& $24 \mathrm{~h}$ & 19.11 & $31.51^{\mathrm{b}}$ & 1.68 \\
& $48 \mathrm{~h}$ & $41.77^{\mathrm{a}}$ & & \\
& & 10.05 & 1.87 \\
& $12 \mathrm{~h}$ & 8.44 & 19.74 & 1.95 \\
& $24 \mathrm{~h}$ & 21.12 & $34.35^{\mathrm{b}}$ & 1.95 \\
\hline
\end{tabular}

${ }^{1}$ Standard error of the LSMeans

${ }^{\mathrm{a}-\mathrm{c}}$ Means within a row with different subscripts differ, $P \leq 0.05$ 
Table 2.14

Differences in \%DMD between annual and perennial grasses at four growth stages.

\begin{tabular}{lccc}
\hline & \multicolumn{2}{c}{ Growth Type } & \multirow{2}{*}{ SE $^{1}$} \\
\cline { 2 - 3 } Growth Stage & Annual & Perennial & 1.78 \\
\hline Late vegetative & 25.71 & 24.5 & 2.12 \\
Early reproductive & 22.44 & 20.46 & 2.07 \\
Late reproductive & $21.03^{\mathrm{a}}$ & $15.81^{\mathrm{b}}$ & 1.78 \\
Dry & $21.4^{\mathrm{a}}$ & $16.83^{\mathrm{b}}$ & \\
\hline
\end{tabular}

${ }^{1}$ Standard error of the LSMeans

${ }^{\mathrm{a}-\mathrm{c}}$ Means within a row with different subscripts differ, $P \leq 0.05$ 
Table 2.15

Differences in dry matter digestibility (\%DMD) between each growth stage across annuals and across perennials.

\begin{tabular}{cccccc}
\hline & \multicolumn{4}{c}{ Growth Stage } & \\
\cline { 2 - 5 } Growth Type & LV & ER & LR & D \\
\hline Annual & $25.71^{\mathrm{a}}$ & $22.44^{\mathrm{b}}$ & $21.03^{\mathrm{b}}$ & $21.4^{\mathrm{b}}$ & 2.46 \\
Perennial & $24.5^{\mathrm{a}}$ & $20.46^{\mathrm{b}}$ & $15.81^{\mathrm{cd}}$ & $16.83^{\mathrm{d}}$ & 1.65 \\
\hline
\end{tabular}

${ }^{1}$ Standard error of the LSMeans

${ }^{\mathrm{a}-\mathrm{c}}$ Means within a row with different subscripts differ, $P \leq 0.05$ 


\section{ABBREVIATIONS}
AA - amino acid
AU - animal unit
ADF - acid detergent fiber
ADL - acid detergent lignin
$\mathrm{BW}$ - body weight
$\mathrm{CF}$ - crude fiber
$\mathrm{CP}$ - crude protein
D - dry

DADF - digestible acid detergent fiber

DADL - digestible acid detergent lignin

DE - digestible energy

DMB - dry matter basis

DMD - dry matter digestibility

DMI - dry matter intake

DNDF - digestible neutral detergent fiber

EE - energy efficiency

ENE - estimated net energy

ER - early reproductive

IF - indigestible fraction

ISDMD - in situ dry matter disappearance

MCP - microbial crude protein

ME - metabolizable energy

MP - metabolizable protein

NDF - neutral detergent fiber

NDFD - neutral detergent fiber digestibility

$\mathrm{NE}$ - net energy

$\mathrm{NEI}$ - net energy intake

NFC - non-fiber carbohydrates

NFE - nitrogen free extract

NPN - non-protein nitrogen

NRC - national research council

$\mathrm{NV}$ - nutritive value

$\mathrm{LR}$ - late reproductive

LV - late vegetative

$\mathrm{OM}$ - organic matter

RDM - residual dry matter

$\mathrm{RDP}$ - rumen degradable protein

RFQ - relative forage quality

RFV - relative forage value

RUP - rumen undegradable protein

SJER - San Joaquin Experimental Range

TDN - total digestible nutrients 


\section{REFERENCES}

Aderibidbe, A.O., Church, D.C., 1980. Palatability of four varieties of ryegrass by cattle, in: Proceedings: Western Society, American Society of Animal Science. Corvallis, pp. 205209.

Arzani, H., Torkan, J., Jafari, M., Nikkhah, A., 2001. Investigation on effects of phenological stages and environmental factors (soil and climate) on forage quality of some important range species. J. Agric. Sci. 32, 385-397.

Arzani, H., Zohdi, M., Fish, E., Zahedi Amiri, G.H., Nikkhah, A., Wester, D., 2004.

Phenological effects on forage quality of five grass species. J. Range Manag. 57, 624629. doi:10.2458/azu_jrm_v57i6_arzani

Atkinson, C.J., 1986. The effect of clipping on net photosynthesis and dark respiration rates of plants from an upland grassland, with reference to carbon partitioning in Festuca ovina. Ann. Bot. 58, 61-62.

Bailey, R.W., 1973. Structural Carbohydrates, in: Butler, G.W., Bailey, R.W. (Eds.), Chemistry and Biochemistry of Herbage, Volume I. Academic Press, London and New York, pp. $157-211$.

Baker, D., Norris, K.H., Li, B.W., 1979. Food fiber analysis: Advances in methodology, in: Inglett, G.E., Falkehag, S.I. (Eds.), Dietary Fibers Chemistry and Nutrition. Academic Press, New York, pp. 67-78.

Barry, S., Larson, S., George, M., 2006. California native grasslands: A historical perspective - A guide for developing realistic restoration objectives. Grasslands 16, 7-11.

Bartolome, J.W., Fehmi, J.S., Jackson, R.D., Allen-Diaz, B., 2004. Response of a native perennial grass stand to disturbance in California's Coast Range Grassland. Restor. Ecol. 12, 279-289. doi:10.1111/j.1061-2971.2004.00355.x

Bentley, J.R., Talbot, M.W., 1948. Annual - plant vegetation of the California foothills as related to range management. Ecology 29, 72-79. doi:10.2307/1930345

Black, J.L., Kenney, P.A., 1984. Factors affecting diet selection by sheep. I Potential intake rate and acceptability of feed. Aust. J. Agric. Res. 35, 551-563.

Boekholt, H.A., van Es, A., Preston, R.L., 1972. Protein requirements for growing and lactating ruminants, in: University of Nottingham 6th Nutritional Conference of Feed Manufacturers. Wageningen, Nottingham, p. 22.

Bohnert, D.W., DelCurto, T., Clark, A.A., Merrill, M.L., Falck, S.J., Harmon, D.L., 2011. Protein supplementation of ruminants consuming low-quality cool- or warm-season forage: Differences in intake and digestibility. J. Anim. Sci. 89, 3707-3717. doi:10.2527/jas.2011-3915

Bohnert, D.W., Schauer, C.S., Bauer, M.L., DelCurto, T., 2002a. Influence of rumen protein degradability and supplementation frequency on steers consuming low-quality forage: I. Site of digestion and microbial efficiency. J. Anim. Sci. 80, 2967-2977. doi: $10.2527 / 2002.80112967 x$

Bohnert, D.W., Schauer, C.S., DelCurto, T., 2002b. Influence of rumen protein degradability and supplementation frequency on performance and nitrogen use in ruminants consuming low-quality forage: Cow performance and efficiency of nitrogen use in wethers. J. Anim. Sci. 80, 1629-1637. doi:10.2527/2002.80112967x

Bohnert, D.W., Schauer, C.S., Falck, S.J., Delcurto, T., 2002c. Influence of rumen protein degradability and supplementation frequency on steers consuming low-quality forage: II. 
Ruminal fermentation characteristics. J. Anim. Sci. 80, 2978-2988.

doi: $10.2527 / 2002.80112978 x$

Bosman, M.S.M., 1967. no title. Meded., Inst. Biol. Scheikd. Onderz. Landbouwgewassen, Wageningen 349, 97-100.

Briske, D.D., Heitschmidt, R.K., 1991. Humans, grazing, and ecological systems, in: Heitschmidt, R.K., Stuth, J.W. (Eds.), Grazing Management: An Ecological Perspective. Timber Press, Inc., Portland, pp. 11-26.

Briske, D.D., Richards, J.H., 1995. Plant responses to defoliation: a physiological, morphological and demographic evaluation, in: Bedunah, D.J., Sosebee, R.E. (Eds.), Wildland Plants: Physiological Ecology and Developmental Morphology. Society for Range Management, Denver, CO, pp. 635-710.

Buckner, C.D., Klopfenstein, T.J., Watson, A.K., Macdonald, J.C., Schacht, W.H., Schroeder, P., 2013. Ruminally undegradable protein content and digestibility for forages using the mobile bag in situ technique. J. Anim. Sci. 91, 2812-2822. doi:10.2527/jas2012-5982

CDFA, 2016. California agricultural statistics review, 2015-2016. Sacramento.

CDFF, 1988. California's Forests and Rangelands: Growing Conflict Over Changing Uses.

Chiariello, N.R., 1989. Phenology of California Grasslands, in: Hueneke, L.F., Mooney, H.A. (Eds.), Grassland Structure and Function: California Annual Grassland. Kluwer Academic Publishers, Dordrecht, Netherlands, pp. 45-58.

Clements, F.E., 1934. The relict method in dynamic ecology. J. Ecol. 22, 39-68.

Davis, F.W., Stoms, D.M., Hollander, A.D., Thomas, K.A., Stine, P.A., Odion, D., Borchert, M.I., Thorne, J.H., Gray, M.V., Walker, R.E., Warner, K., Graae, J., 1988. The California Gap Analysis Project-Final Report. Santa Barbara.

Dulphy, J.P., Demarquilly, C., 1994. The regulation and prediction of feed intake in ruminants in relation to feed characteristics. Livest. Prod. Sci. 39, 1-12. doi:10.1016/03016226(94)90147-3

Elliot, R.C., Fokkema, K., French, C.H., 1961. no title. Rhod. Agric. J. 58, 124-130.

El-Shazly, K., Dehority, B.A., Johnson, R.R., 1961. Effect of starch on the digestion of cellulose in vitro and in vivo by rumen microorganisms. J. Anim. Sci. 20, 268-273.

Fahey, G.C., Berger, L.L., 1988. Carbohydrate nutrition of ruminants, in: Church, D.C. (Ed.), The Ruminant Animal - Digestive Physiology and Nutrition. Prentice Hall, Inc., New Jersey, pp. 269-296.

FRAP, 2003. Socio-economic range livestock industry status, in: The Changing California: Forest and Range 2003 Assessment. pp. 1-10.

Fredrickson, E.L., Galyean, M.L., Branine, M.E., Sowell, B., Wallace, J.D., 1993. Influence of ruminally dispensed monensin and forage maturity on intake and digestion. J. Range Manag. 46, 214-220.

Galyean, M.L., Goetsch, A.L., 1993. Utilization of forage fiber by ruminants, in: Jung, H.G., Buxton, D.R., Hatfield, R.D., Ralph, J. (Eds.), Forage Cell Wall Structure and Digestibility. ASA-CSSA-SSSA, Madison, pp. 33-71.

Ganskopp, D., Bohnert, D., 2001. Nutritional Dynamics of 7 Northern Great Basin Grasses. J. Range Manag. 54, 640-647.

Ganskopp, D.C., Bohnert, D.W., 2009. Landscape nutritional patterns and cattle distribution in rangeland pastures. Appl. Anim. Behav. Sci. 116, 110-119.

doi:10.1016/j.applanim.2008.10.006 
Garnier, E., 1992. Growth Analysis of Congeneric Annual and Perennial Grass Species. J. Ecol. $80,665-675$.

George, M., Bartolome, J., McDougald, N., Connor, M., Vaughn, C., Markegard, G., 2001a. Annual range forage production. ANR Publication 8018.

George, M., Bell, M.E., 2001. Using stage of maturity to predict the quality of annual range forage. ANR Publication 8019.

George, M., Nader, G., Dunbar, J., 2001b. Balancing beef cow nutrient requirements and seasonal forage quality on annual rangeland. ANR Publication 8021.

George, M.R., Fulgham, K.O., 1989. Grazing systems and management of Mediterranean-type plant communities.

George, M., Rice, K., 2017. Range plant growth and development. UC Rangelands Res. Educ. Arch. http://rangelandarchive.ucdavis.edu/Annual_Rangeland_Handbook/Range_Plant_ Growth_and_Development/ (accessed 7.30.17).

Gomez, A., Mendoza, G.D., Garcìa-Bojalil, C., Barcena, R., Ramos, J.A., Crosby, M.M., PinosRodríguez, J.M., Lara, A., 2011. Effect of supplementation with urea, blood meal, and rumen-protected methionine on growth performance of Holstein heifers grazing kikuyu pasture. Trop. Anim. Health Prod. 43, 721-724. doi:10.1007/s11250-010-9759-Z

Gordon, A., Sampson, A.W., 1939. Composition of California foothill plants as a factor in range management. Bulletin 627.

Green, L., Bentley, J., 1957. Forest research notes.

Gustavsson, A., Martinsson, K., 2004. Seasonal variation in biochemical composition of cell walls , digestibility, morphology, growth and phenology in timothy. Eur. J. Agron. 20, 293-312. doi:10.1016/S1161-0301(03)00041-8

Hart, R.H., Ashby, M.M., 1998. Grazing intensities, vegetation, and heifer gains: 55 years on shortgrass. J. Range Manag. 51, 392-398.

Hatch, D.A., Bartolome, J.W., Fehmi, J.S., Hillyard, D.S., 1999. Effects of burning and grazing on a coastal California grassland. Restor. Ecol. 7, 376-381. doi:10.1046/j.1526100X.1999.72032.x

Hatfield, R., Fukushima, R.S., 2005. Can lignin be accurately measured? Crop Sci. 45, 832-839. doi: $10.2135 /$ cropsci2004.0238

Heady, H.G., 1977. Terrestrial grassland, in: Barbour, M.G., Major, J. (Eds.), Terrestrial Vegetation of California. John Wiley, New York, pp. 491-514.

Henneman, C., Seavy, N.E., Gardali, T., 2014. Restoring native perennial grasses by changing grazing practices in central coastal California. Ecol. Restor. 32, 352-354. doi:10.3368/er.32.4.352

Henzell, E.F., Ross, P.J., 1973. The nitrogen cycle of pasture ecosystems, in: Butler, G.W., Bailey, R.W. (Eds.), Chemistry and Biochemistry of Herbage. Academic Press, London and New York, pp. 81-129.

Hersom, M.J., 2008. Opportunities to enhance performance and efficiency through nutrient synchrony in forage-fed ruminants. J. Anim. Sci. 86, E306-E317. doi:10.2527/jas.20070463

Hess, B.W., Scholljegerdes, E.J., Coleman, S.A., Williams, J.E., 1998. Supplemental protein plus ruminally protected methionine and lysine for primiparous beef cattle consuming annual rye hay. J. Anim. Sci. 76, 1767-1777. 
HilleRisLambers, J., Yelenik, S.G., Colman, B.P., Levine, J.M., 2010. California annual grass invaders: The drivers or passengers of change? J. Ecol. 98, 1147-1156.

doi:10.1111/j.1365-2745.2010.01706.x

Hodgson, J., 1986. The significance of sward characteristics in the management of temperate sown pastures, in: Proceedings of the XVth International Grassland Congress. The Japanese Society of Grassland Science, Nishinasuno, Japan, pp. 63-67.

Hoehne, O.E., Clanton, D.C., Streeter, C.L., 1968. Chemical composition and in vitro digestibility of forbs consumed by cattle grazing native range. J. Range Manag. 21, 5-7. doi: $10.2307 / 3896233$

Hormay, A.L., 1940. Forest research notes: Palatabilities of foothill range plants for cattle. Forest Service U.S. Department of Agriculture, Berkeley.

Horn, B.E., 2003. Mineral content of range grass.

Huhtanen, P., Ahvenjärvi, S., Weisbjerg, M.R., Nørgaard, P., 2008. Digestion and passage of fibre in ruminants, in: Sejrsen, K., Hvelplun, T., Nielsen, M.O. (Eds.), Ruminant Physiology: Digestion, Metabolism and Impact of Nutrition on Gene Expression, Immunology and Stress. Wageningen Academic Publishers, The-Netherlands, pp. 87135.

Huntington, G.B., Magee, K., Matthews, A., Poore, M., Burns, J., 2009. Urea metabolism in beef steers fed tall fescue, orchardgrass, or gamagrass hays. J. Anim. Sci. 87, 1346-1353. doi:10.2527/jas.2008-1444

Huston, J.E., Pinchak, W.E., 1991. Range animal nutrition, in: Heitschmidt, R.K., Stuth, J.W. (Eds.), Grazing Management: An Ecological Perspective. Timber Press, Inc., Portland, pp. 27-63.

Ingram, R., 1999. Controlled Grazing on Foothill Rangelands.

Jackson, L.E., 1985. Ecological origins of California's Mediterranean grasses. J. Biogeogr. 12, 349-361.

Jackson, R.D., Bartolome, J.W., 2007. Grazing Ecology of California Grasslands, in: Stromberg, S.R., Corbin, J.D., D’Antonio, C.M. (Eds.), California Grasslands: Ecology and Management. University of California Press, Berkeley and Los Angeles, pp. 197-206.

Jones, B.J., Love, R.M., 1945. Improving California ranges. Berkeley.

Jung, H.G., Allen, M.S., 1995. Characteristics of plant cell walls affecting intake and digestibility of forages by ruminants. J. Anim. Sci. 73, 2774-2790. doi:/1995.7392774x

Kalra, Y.P., 1998. Handbook of reference for plant analysis. CRC Press, Inc., Boca Raton.

Kellaway, R.C., Ison, R.L., Li, X., Annison, G., 1993a. The nutritive value of alternative legumes, in: Michalk, D.L., Craig, A.D., Collins, W.J. (Eds.), Alternative Pasture Legumes. Primary Industries South Australia, pp. 176-187.

Kellaway, R.C., Ison, R.L., Li, X., Annison, G., 1993b. The nutritive value of alternative legumes, in: Michalk, D.L., Craig, A.D., Collins, W.J. (Eds.), Alternative Pasture Legumes. Primary Industries South Australia, pp. 176-187.

Kellner, O., 1912. Kie Ernährung der landwirtschaftlichen Nutztiere.

Laca, E.A., 2015. Evaluation of forage quality and selectivity by livestock of native perennial and introduced grasses.

Lalman, D., 1990. Nutrient requirements of beef cattle. Dep. Anim. Sci. , Oklahoma Coop. Ext. Serv. Div. Agric. Sci. Nat. Resour.

Laude, H.M., 1953. The nature of summer dormancy in perennial grasses. Bot. Gaz. 114, 284292. 
Leigh, J.H., Mulham, W.E., 1966. Selection of diet by sheep grazing semi-arid pastures on the Riverine plain. 1. A bladder saltbush (Atriplex vesicaria) - cotton bush (Kochia aphylla) community. Aust. J. Exp. Agric. Anim. Husb. 6, 460-467.

Leng, R.A., 1973. Salient features of the digestion of pastures by ruminants and other herbivores, in: Butler, G.W., Bailey, R.W. (Eds.), Chemistry and Biochemistry of Herbage, Volume III. Academic Press, London and New York, pp. 81-129.

Lulow, M.E., 2008. Restoration of California native grasses and clovers: The roles of clipping, broadleaf herbicide, and native grass density. Restor. Ecol. 16, 584-593. doi:10.1111/j.1526-100X.2007.00334.x

Manske, L.L., 1999. General description of grass growth and development and defoliation resistance mechanisms. Dickinson.

McCall, R., 1940. The digestibility of mature range grasses and range mixtures fed alone and with supplements. J. Agric. Res. 60, 39-50.

McLeod, M.N., Minson, D.J., 1976. The analytical and biological accuracy of estimating the dry matter digestibility of different legume species. Anim. Feed Sci. Technol. 1, 61-72.

Mehrez, A.Z., Ørskov, E.R., 1977. A study of the artificial bag technique for determining the digestibility of feeds in the rumen. J. Agric. Sci. Cambridge 88, 645.

Merchen, N.R., 1988. Digestion, absorption and excretion in ruminants, in: Church, D.C. (Ed.), The Ruminant Animal - Digestive Physiology and Nutrition. Prentice Hall Inc., New Jersey, pp. 172-201.

Mertens, D.R., 1994. Regulation of forage Intake, in: Fahey, G.C., Collins, M., Mertens, D.R., Moser, L.E. (Eds.), Forage Quality, Evaluation, and Utilization. American Society of Agronomy, Crop Science Society of America, and Soil Science Society of America, Madison, pp. 494-532.

Mertens, D.R., 1983. Using neutral detergent fiber to formulate dairy rations and estimate the net energy content of forages, in: Cornell Nutrition Conference for Feed Manufacturers. Athens, pp. 60-68.

Meuret, M., Provenza, F.D., 2015. When art and science meet: integrating knowledge of French herders with science of foraging behavior. Rangel. Ecol. Manag. 68, 1-17.

Minson, D.J., 1990. Forage in ruminant nutrition. Academic Press, San Diego.

Minson, D.J., Kemp, C.D., 1961. Studies in the digestibility of herbage. 9. Herbage and faecal nitrogen as indicators of herbage organic matter digestibility. J. Br. Grassl. Soc. 16, 7679.

Moore, J.E., Brant, M.H., Kunkle, W.E., Hopkins, D.I., 1999. Effects of supplementation on voluntary forage intake, diet digestibility, and animal performance. J. Anim. Sci. 77, $122-135$.

Moore, K.J., Jung, H.G., 2001. Lignin and fiber digestion 54, 420-430.

Moore, L.A., Irvin, H.M., Shaw, J.C., 1953. Relationship between TDN and energy values of feeds. J. Dairy Sci. 36, 93-97. doi:10.3168/jds.S0022-0302(53)91464-7

Murray, R.B., Mayland, H.F., Van Soest, P.J., 1978. Growth and nutritional value to cattle of grasses on cheatgrass range in southern Idaho (INT-199). Ogden, Utah.

National Forage and Grasslands Curriculum, 2016. Differentiate warm-season from cool-season grasses. http://forages.oregonstate.edu/nfgc/eo/onlineforagecurriculum/ (accessed 12.6.17).

NFTA, 2016. Relative feed value index. http://www.foragetesting.org/lab_procedure/appendix/A/RFVIndex.htm 
NRC, 2000. Energy, in: Nutrient Requirements of Beef Cattle. National Academy Press, Washington, D.C., pp. 3-13.

National Research Council, 1996. Nutrient requirements of beef cattle, Seventh. ed. National Academy Press, Washington, D.C.

National Research Council, 1987. Predicting feed intake of food-producing animals.

National Research Council, 1982. United States-Canadian tables of feed composition.

Oregon State University, n.d. The culm. http://bpp.oregonstate.edu/files/bpp/webfm/pdf/bot414/culm.pdf (accessed 6.28.17).

Owens, F.N., Zinn, R., 1988. Protein metabolism of ruminant animals, in: Church, D.C. (Ed.), The Ruminant Animal: Digestive Physiology and Nutrition. Waveland Press, Inc., New Jersey, pp. 227-249.

Pearson, C.J., Ison, R.L., 1997. Agronomy of grassland systems, Second. ed. Cambridge University Press, New York.

Peterson, P.M., Soreng, R.J., 2007. Systematics of California grasslands (Poacea), in: Stromberg, S.R., Corbin, J.D., D’Antonio, C.M. (Eds.), California Grasslands: Ecology and Management. University of California Press, Berkeley and Los Angeles, pp. 7-20.

Phillips, W.A., Northup, B.N., Venuto, B.C., 2009. Dry matter intake and digestion of perennial and annual cool- season grasses by sheep. Prof. Anim. Sci. 25, 610-618.

Provenza, F.., Villalba, J.., Dziba, L.., Atwood, S.., Banner, R.., 2003. Linking herbivore experience, varied diets, and plant biochemical diversity. Small Rumin. Res. 49, 257274. doi:10.1016/S0921-4488(03)00143-3

Provenza, F.D., Meuret, M., Gregorini, P., 2015. Our landscapes, our livestock, ourselves: Restoring broken linkages among plants, herbivores, and humans with diets that nourish and satiate. Appetite. doi:10.1016/j.appet.2015.08.004

Putnam, G.H., Robinson, P., DePeters, E., 2007. Forage quality and testing, in: Irrigated Alfalfa Management in Mediterranean and Desert Zones. University of California Agriculture and Natural Resources, Oakland, pp. 1-25.

Reever Morghan, K.J., Corbin, J.D., Gerlach, J., 2007. Water relations, in: Stromberg, S.R.Corbin, J.D., D’Antonio, C.M. (Ed.), California Grasslands: Ecology and Management. University of California Press, Berkeley and Los Angeles, pp. 87-93.

Reid, C.S.W., 1973. Limitations to the productivity of the herbage-fed ruminant that arise from the diet, in: Butler, G.W., Bailey, R.W. (Eds.), Chemistry and Biochemistry of Herbage, Volume III. Academic Press, London and New York, pp. 215-257.

Rodgers, P., 1995. Poisoning in cattle and sheep by urea nitrates and nitrites: Sources, toxic doses, treatment and prevention. Meath, Ireland.

Saha, U., Sonon, L., Hanncock, D., Hill, N., Stewart, L., Heusner, G., Kissel, D.E., 2013. Common terms used in animal feeding and nutrition. Univ. Georg. Coop. Ext.

Sedivec, K., Russell, I., Vader, K., Tober, D., Eriksmoen, E., 1997. Nutrient composition of selected cool-season grasses near Hettinger, North Dakota, Grasses for the Norther Plains, Volume I - Cool Season, R-1323.

Senft, R.L., 1989. Herbivore foraging models: Effects of stocking and landscape composition on simulated resource use by cattle. Ecol. Model. 46, 283-303.

Sewell, H.B., 1993. Urea supplements for beef cattle.

Shepherd, J.B., Wiseman, H.G., Ely, R.E., Melin, C.G., Sweetman, W.J., Gordon, C.H., Schoenleber, L.G., Wagner, R.E., Campbell, L.E., Roane, G.D., Hosterman, W.H., 1954. Experiments in harvesting and preserving alfalfa for dairy cattle feed. 
Smith, D., 1973. The nonstructural carbohydrates, in: Butler, G.W., Bailey, R.W. (Eds.), Chemistry and Biochemistry of Herbage, Volume I. Academic Press, London and New York, p. 123.

Soder, K.J., Gregorini, P., Scaglia, G., Rook, A.J., 2009. Dietary selection by domestic grazing ruminants in temperate pastures: Current state of knowledge, methodologies, and future direction. Rangel. Ecol. Manag. 62, 389-398. doi:10.2111/08-068.1

Stuth, J.W., 1991. Foraging behavoir, in: Heitschmidt, R.K., Stuth, J.W. (Eds.), Grazing Management: An Ecological Perspective. Timber Press, Inc., Portland, pp. 65-83.

Sullivan, 1964. Chemical composition of forages. Washington, D.C.

Sun, X.Z., Waghorn, G.C., Clark, H., 2010. Composition and in sacco degradation characteristics of winter growth of Lolium perenne, Lolium multiflorum, and Lolium perenne $\mathrm{x}$ multiflorum ryegrasses, in: Proceedings of the New Zealand Society of Animal Production. Palmerston, pp. 206-211.

Tessema, Z., Baars, R.M.T., 2006. Chemical composition, dry matter production and yield dynamics of tropical grasses mixed with perennial forage legumes. Trop. Grasslands 40, $150-156$.

Tharmaraj, J., Chapman, D.F., Nie, Z.N., Lane, A.P., 2008. Herbage accumulation, botanical composition, and nutritive value of five pasture types for dairy production in southern Australia. Aust. J. Agric. Res. 59, 127-138. doi:10.1071/AR07083

Theander, O., Åman, P., 1979. The chemistry, morphology and analysis of dietary fiber components, in: Inglett, G.E., Falkehag, S.I. (Eds.), Dietary Fibers Chemistry and Nutrition. Academic Press, New York, pp. 215-244.

U.S. Department of Agriculture, 2015. California non-federal grazing land. 2012 Natl. Resour. Invent. www.nrcs.usda.gov/Internet/NRCS_RCA/reports/nri_graz_ca.html (accessed 1.1.17).

U.S. Department of Agriculture, 2014. Agricultural statistical overview. Calif. Agric. Stat. Rev. 2013-2014. https://www.cdfa.ca.gov/statistics/pdfs/2013/AgStatsOverview.pdf (accessed 1.1.16).

Ulyatt, M.J., 1973. The feeding value of herbage, in: Butler, G.W., Bailey, R.W. (Eds.), Chemistry and Biochemistry of Herbage, Volume III. London and New York, London and New York, pp. 131-178.

UNL Beef, 2016. Understanding feed analysis. http://beef.unl.edu/learning/feedanalysis.shtml (accessed 8.8.16).

USDA-NASS, 2013. Census of agriculture--state data, cattle inventory by class. http://usda01.library.cornell.edu/usda/nass/Catt/2010s/2013/Catt-02-01-2013.pdf (accessed 2.5.17).

USDA-NRCS, 2017. Plants database. https://plants.usda.gov/java/ (accessed 6.30.17).

USGS, 2016. California drought: Drought facts. Calif. Water Sci. Cent. http://ca.water.usgs.gov/data/drought/ (accessed 1.1.16).

Van Soest, P.J., 1994. Nutritional ecology of the ruminant, Second. ed. Cornell University Press, Ithaca.

Villalba, J.J., Provenza, F.D., Catanese, F., Distel, R.A., 2015. Understanding and manipulating diet choice in grazing animals. Anim. Prod. Sci. 55, 261. doi:10.1071/AN14449

Waterman, R.C., Caton, J.S., Loest, C.A., Petersen, M.K., Roberts, A.J., 2014. Beef species symposium: An assessment of the 1996 Beef NRC: metabolizable protein supply and 
demand and effectiveness of model performance prediction of beef females. J. Anim. Sci. 92, 2785-2799. doi:10.2527/jas2013-7062

Weder, C.E., DelCurto, T., Svejcar, T., Jaeger, J.R., Bailey, R.K., 1999. Influence of supplemental alfalfa quality on the intake, use, and subsequent performance of beef cattle consuming low-quality roughages. J. Anim. Sci. 77, 1266-1276. doi: $10.2527 / 1999.7751266 x$

Weir, W.C., Torell, D.T., 1959. Selective grazing by sheep as shown by a comparison of the chemical composition of range and pasture forage obtained by hand clipping and that collected by esophageal-fistulated sheep. J. Anim. Sci. 18, 641-649.

Weston, R.H., 1985. The regulation of feed intake in roughage-fed ruminants, in: Nutrition Society of Australia. pp. 55-62.

White, H.E., Wolf, D.D., 2009. Controlled grazing of Virginia's pastures. Publication 418-012. Petersburg.

Wilson, J.R., 1986. An interdisciplinary approach for increasing yield and improving quality of forages, in: Proceedings of the XVth International Grassland Congress. The Japanese Society of Grassland Science, Nishinasuno, Japan, pp. 49-55.

Wrysinski, J., Robins, P., Veserat, G., 1998. Native grass forage quality pilot study. Grasslands $8,3-5$. 


\section{APPENDICES}

\section{Appendix A: Plant Collection Procedures}

Author: Elaina Cromer

Revision date: June 2016

Materials:

- Grass clippers

- Permanent marker

- $\quad$ Brown paper bags (5-7/sample)

- GPS

- Hand lense

- $\quad 300 \mathrm{~g}$ of grass (at min

Sample Collection Procedure

1. Pinpoint a general location where the desired grass species can be found. Using the GPS, create a waypoint (consult corresponding GPS manual for instructions on marking locations). Label the waypoint with the USDA Plants Profile assigned code name (eg. NALE2 for Nasella pulchra), for the specific grass species. Also include the stage of growth [V=vegetative, $\mathrm{ER}=$ =arly reproductive, $\mathrm{LR}=$ late reproductive, Dry] that it was collected at. Try to collect the entire sample within a 1-mile radius so as to minimize variability in soil type.

2. With a permanent marker, label the brown paper bags with the sample collection date, the species code for the grass sample to be collected, the stage of growth [V=vegetative, ER=early reproductive, $\mathrm{LR}=$ late reproductive, Dry], and the name assigned to the location where the sample will be collected from.

3. In non-cultivated grasslands, each grass species may require a unique collection technique to be adopted. Depending on the species type and the environment that it is growing in, the grass may grow large bunches (Nasella pulchra), in large continuous swards (Lolium multiflorum), or sparsely distributed (Elymus glaucus). These patterns will impact ease of collecting and the time required for collection. Individuals of a species that tend to grow in close proximity to one another will take less time, and species that are sparsely distributed will take more time. Planning collection times with this knowledge in mind is critical as the growing season is constantly progressing.

4. Individuals from the same species that grow within close proximity to one another can be clipped in large bunches all at once and any non-desired species can be sorted out of the bunch. If there is an overwhelming number of non-desired species mixed in with the samples species it may be best to clip each individual separately. 
5. Clip the grasses approximately 1 to 3 inches from the soil surface. Try not to include any soil or roots in the sample.

6. When a bunch of grass (small enough for a hand to wrap around it) has been acquired, fold it at a length equidistant to the length of the paper bag. Continue folding the entire bunch so that it fits in the paper bag neatly.

7. Collect enough bunches to fill the paper bag three quarters of the way, fold the bag shut, and start a new bag until 5 to 7 bags have been filled (approximately $300 \mathrm{~g}$ ).

8. Within 3 hours or less of the collection, get the brown paper bags containing the grass samples into a drying oven that is set to $80^{\circ} \mathrm{F}$ or $27^{\circ} \mathrm{C}$. Let the samples dry for 24-48 hours. High water content samples (LV and ER in particular) should be dried at $100^{\circ} \mathrm{F}$ or $55^{\circ} \mathrm{C}$.

9. Remove from drying oven and store in a dark, dry room at an ambient temperature.

10. Maintain a clear record in a designated notebook of the collection date, the USDA Plants Profile assigned code name, the genus and species names, and notes including: the stage of growth the sample was collected at; how much sample was collected; how much sample is left to be collected; what the sample looked like (try to use specific morphological trait descriptions); surrounding environment; what unexpected difficulties (if any) were encountered during the sample collection that could be avoided in the future; and any questions.

11. Lastly, grasses should be ground using a medium to large sized Wiley Mill, through a $4 \mathrm{~mm}$ screen. Attach a large Whirlpak bag or storage bag to the chute, where the ground sample is funneled out the bottom. Continue to store ground grass samples in a dark, dry room at an ambient temperature.

NOTE: For N, NDF, ADF, and ADL analysis, subsamples will need to be taken from larger sample and further ground through a $1 \mathrm{~mm}$ screen. Sample ground to $4 \mathrm{~mm}$ is adequate for in situ. 
Appendix B: Plant Collection Site Maps

Grass Species Collected at Camp San Luis

San Luis Obispo, CA

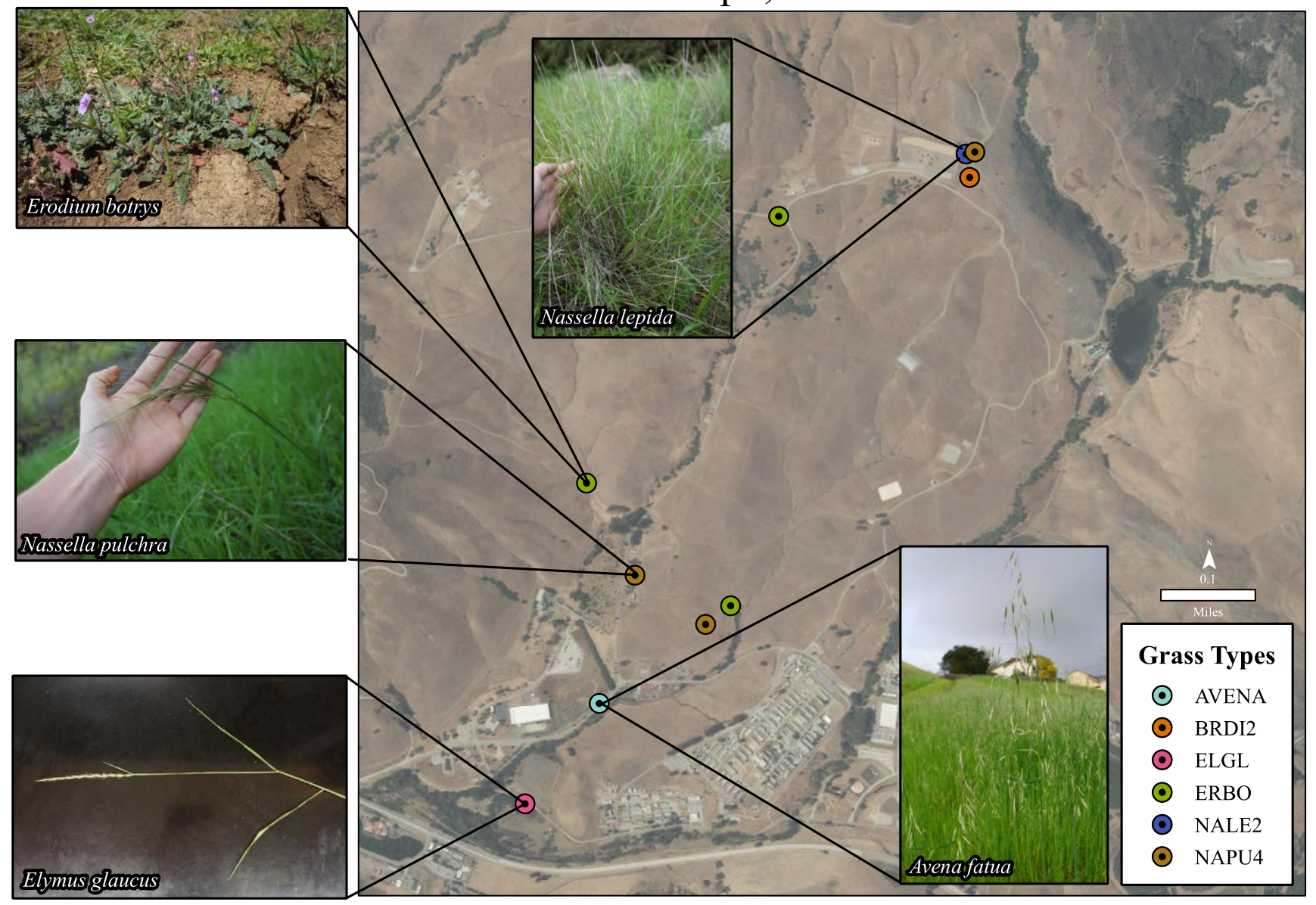




\section{Grass Species Collected at Irish Hills}

San Luis Obispo, CA
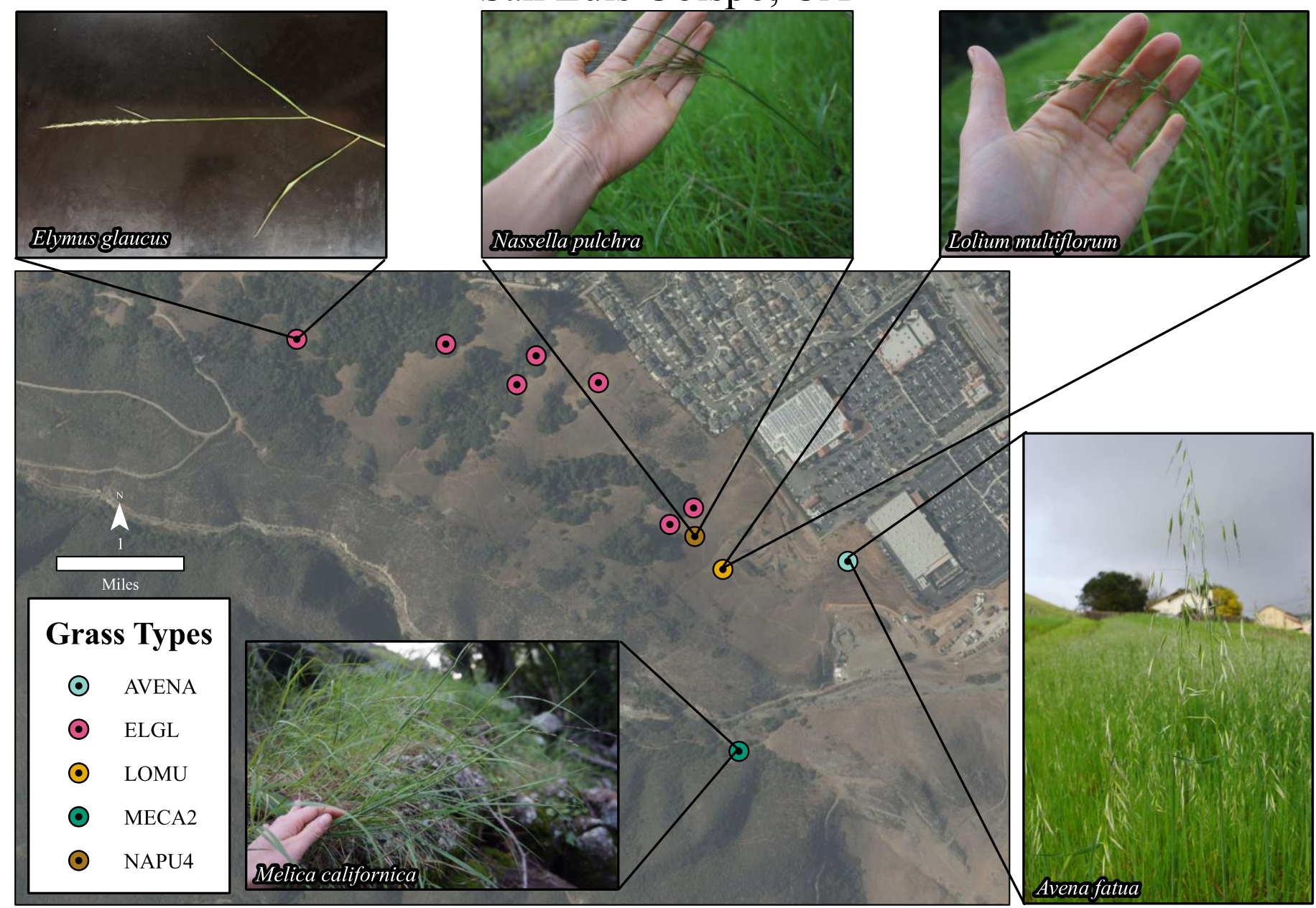
Grass Species Collected at Poly Canyon San Luis Obispo, CA

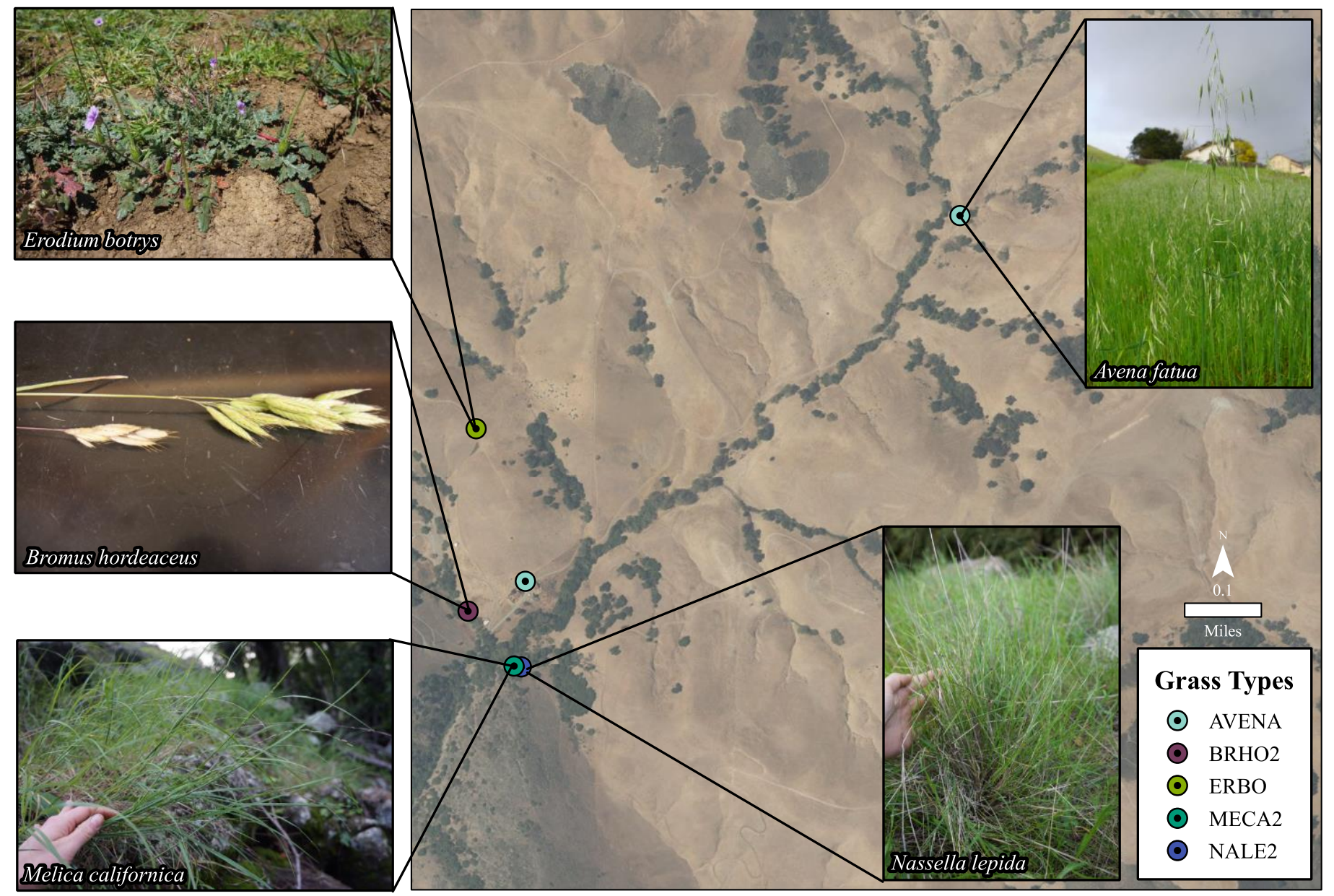


Grass Species Collected at Walters Ranch San Luis Obispo, CA

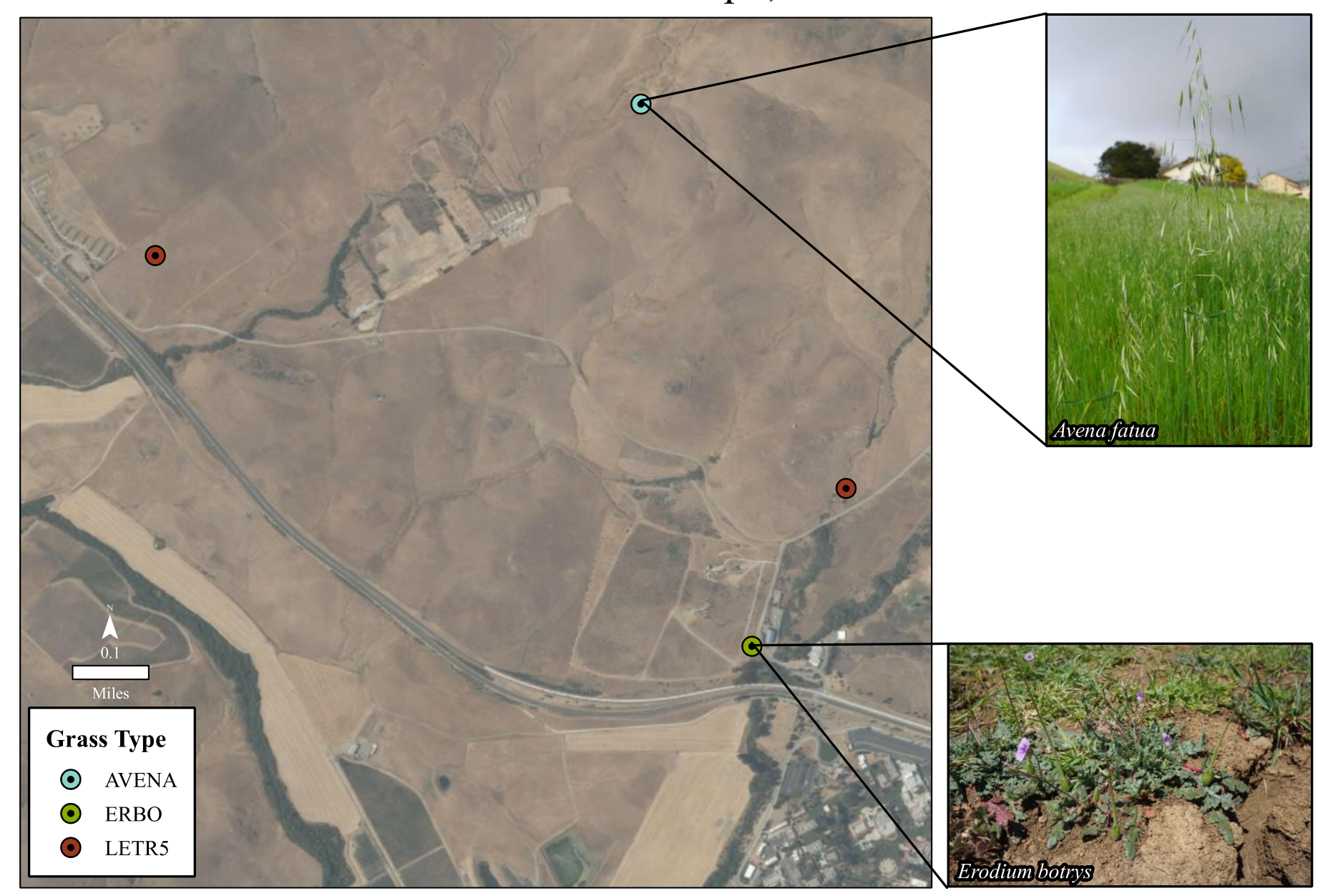




\section{Ruminant Nutrition Lab \\ In situ Digestibility Protocol}

Author: Alexis Ulloa and Elaina Cromer

\section{Materials:}

- Nylon bags

- White nylon string (10 inches)

- Bunsen burner

- Large lingerie bags (x6)

- Metal washers (x24)

- Colored thick string (x2 per color)

- Cannulated cows (x2)

- 5 gallon buckets (x7)

- Air-force drying oven

- Aluminum foil

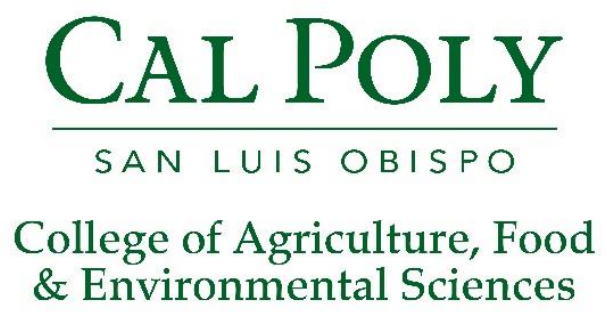

Procedure:

Filling the in situ bags:

1. If new bags, label nylon bags according to the project labeling system. Wash bags through running water inside out and place in air-forced drying oven set at 100C for at least 12 hours. Remove and cool in desiccator for at least 1 hours.

2. If old bags, wash bags through running water inside out and place in air-forced drying oven set at $100 \mathrm{C}$ for at least 12 hours. Remove and cool in desiccator for at least 1 hours.

3. Weigh bags and record weights.

4. Tare scale and add approximately 10 grams of corresponding sample.

5. Tie bags using the protocol attached. (refer to images below as well)

a. Vertically fold the top of the nylon bags three times.

b. Loop one end of a white string and place upside down against the top of the folded bag.

c. Using the long end of the string, loop tightly around the bag at least four time.

d. On final loop, put string through the original open loop.

e. Pull on opposite end of the loop until tie hides under the string.

f. Pull both sides of the string tightly towards opposite ends.

6. Group bags based on cow and time point. (ex: cow A/12 hr)

7. Place grouped nylon bags in large lingerie bag with three metal washers. 
8. Zip lingerie bag and tie end.

9. Securely wrap designated colored thick string to lingerie bag with a labeled metal washer attached to end.

a. $\quad$ Red string $=12 \mathrm{hrs}$

b. Blue string $=24 \mathrm{hrs}$

c. Yellow string $=48 \mathrm{hrs}$

Placing bags in situ (in the rumen):

10. Place corresponding lingerie bags into each cow's rumen using the following technique.

a. Find two cannulated cows and lock them into the head locks.

b. Push on the cannula lid until it pops into the rumen.

c. Grab the lid and turn it on its side to pull it out.

d. Set aside.

e. Using a gloved hand, remove feed from the rumen and begin to form a tunnel down towards the bottom of the rumen (you will feel once you pass the forage mat layer and reach the liquid layer).

f. Grab one lingerie bag at a time and shove it through the tunnel and into the liquid layer.

g. Do this for all time points. (12, 24, $48 \mathrm{hr}$.)

h. Make sure the colored thick string with labeled metal washer hangs out of the rumen.

i. Carefully push the cannula lid back on until you pass the first lip.

j. Slowly continue to push the lid in while bending the sides.

$\mathrm{k}$. Lift the cannula lip up and make sure the lid is properly secured under it.

1. Follow steps b-k for the other cannulated cow.

11. After each time point comes to an end, repeat the steps for removing the cannula lid.

12. Reach into the rumen and remove the appropriate time point bag.

NOTE: In many cases, the bags will become tangled and detangling must be done without removing the other bags from the rumen.

13. Place the lingerie bag into a bucket with water.

14. Perform steps 11-13 for both cows at each time point.

Washing and drying the nylon bags:

15. Prepare six 5 gallon buckets filled half ways with water.

16. Untie the two lingerie bags (one per cow) and remove nylon bags.

17. Place nylon bags into the first wash bucket (include washout bags).

18. Follow the washing method below:

a. Simultaneously, push the bags down and to the right within the water $\times 10$

b. Simultaneously, push the bags down and to the left within the water x10

c. Push bags straight down into the water $\times 10$

19. Remove one bag at a time from the water and compress twice to remove water. 
20. Place compressed bag into the next wash bucket.

21. Perform washing method for a total of 6 times.

22. After the sixth wash, compress the bags twice and place them in a dry bucket.

23. Lay nylon bags on aluminum foil sheet inside an air-forced drying oven preheated to $100 \mathrm{C}$.

24. Leave bags in oven for at least 72 hours.

25. Remove bags from oven and cool in desiccator for at least 1 hour but no more than 2 hours.

26. Untie bags and carefully place back into desiccator.

27. Weigh and record bags.

28. Perform steps 15-26 for each time period. 


\section{Animal Science Department}

Policies and Procedures

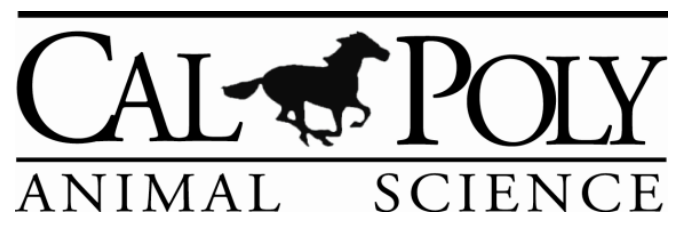

Title:

Gravimetric determination of the dry matter and ash component of feed and fecal samples.

Owner:

Emily Schwartz

Approval:

Mark S. Edwards, Ph.D., Associate Professor

Revision Level:

0.3

Revision Date:

10-May-2017

Scope:

This procedure can be used to determine the ash concentration in feed or fecal samples.

\section{Equipment:}

Reagents:

Safety:

\section{Procedure:}

- Force-air drying oven

- Desiccator

- Coors Crucibles with lids

- Metal Tongs

- Analytical Balance (Mettler Toledo), accurate to $0.1 \mathrm{mg}$

- Kimwipes

- Scoopula

- Muffle Furnace, capable of maintaining a temperature of $600 \pm 20^{\circ} \mathrm{C}$

None

For this procedure the following personal protective equipment (PPE) must be worn:

- Gloves

1. Preheat forced-air drying oven to $100^{\circ} \mathrm{C}$ for a minimum of $3 \mathrm{hr}$ prior to use.

2. Dry empty crucibles must be in oven for a minimum of $2 \mathrm{hr}$ before use. Wet crucibles must be in oven for at least $24 \mathrm{hr}$ prior to use.

3. Using metal tongs place one crucible and cover into desiccator at a time until desired number of crucibles are removed from the oven. Be sure to completely close desiccator in between crucible moving. 
4. Allow crucibles to cool to room temperature for approximately 15 min but no more than $2 \mathrm{hr}$.

5. Weigh and record the weight of the empty crucible and the cover together (W1).

6. Remove the cover and place onto clean Kimwipe.

7. Tare the crucible.

8. Add $2.0000-2.0500 \mathrm{~g}$ of ground sample with scoopula. If excess sample is added to crucible it should be removed and discarded (not be placed back into original sample bag). (W2)

9. Crucibles should be placed into the forced-air drying oven at $100^{\circ}$ $\mathrm{C}$ for a minimum of $24 \mathrm{hr}$. The covers should be removed and placed on the side of the crucible.

10. Crucibles should be removed from oven and placed into desiccator for a minimum of $1 \mathrm{hr}$, but no more than $2 \mathrm{hr}$, to cool to room temperature.

11. Record weight of dry sample plus crucible and cover. (W3). Close desiccator in between weighing.

12. Once crucible has been weighed it should be placed into a second desiccator.

13. Turn Muffle Furnace on before opening. Check internal temperature.

14. Place covered crucibles into Muffle Furnace. Leave covers on.

15. Starting Muffle Furnace:

- Select desired program: Program 1

$\circ$ To determine if correct program is selected use 'Page' button to advance until 'Run List' is displayed. Hit 'Scroll' button and display will show which program is currently selected. To change hit the up or down arrow until desired program is shown. Hit 'Page' button to return to temperature display.

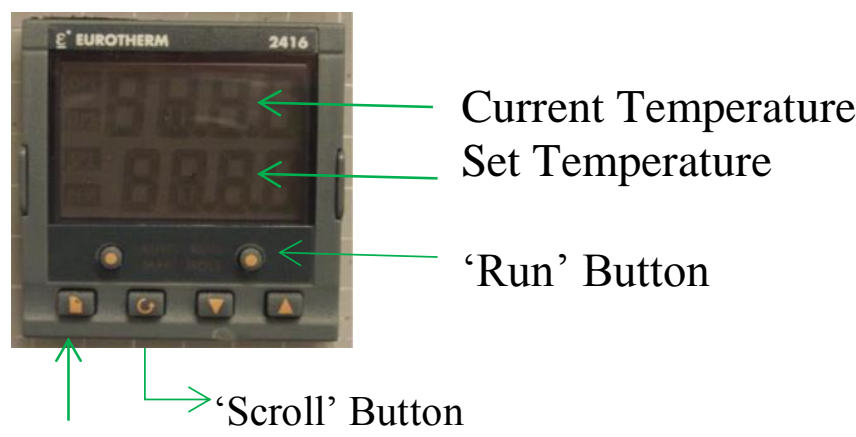




\section{'Page' Button}

16. Push the 'Run' button. Run will be illuminated and the cycle light will begin to flash.

- Muffle furnace will heat to $600^{\circ} \mathrm{C}$ in $3 \mathrm{hr}$.

- Muffle will rest at $600^{\circ} \mathrm{C}$ for $2 \mathrm{hr}$.

- Muffle furnace will then cool to $200^{\circ} \mathrm{C}$ over a period of 5 or more hours.

- Muffle furnace will stay at $200^{\circ} \mathrm{C}$ until crucibles are removed. Once crucibles have been removed push 'Run' button. Run light and the cycle light should turn off.

17. Remove crucibles from the muffle furnace before they cool below $200^{\circ} \mathrm{C}$.

18. Using tongs place the crucibles into a desiccator and allow the crucibles to cool to room temperature for 1 hour (but no more than $2 \mathrm{hr}$ ).

19. Weigh the covered crucibles and ash sample and record the weight to the nearest $0.1 \mathrm{mg}(\mathbf{W 4})$

Ash can be disposed of in trash. Crucibles should be washed and put into forced-air drying oven set at $100^{\circ} \mathrm{C}$. (Oven should not have any samples inside. Water from wet crucibles can add moisture to the air in the oven and effect other samples)

\section{Calculations:}

Laboratory Dry Matter (DM), expressed as a ratio (w/w) of dry matter to initial weight

$$
\% D M=\frac{W 3-W 1}{W 2} \times 100
$$

- Where $\mathrm{W} 1$ = tare weight of crucible and cover in grams

- $\mathrm{W} 2$ = initial weight of sample in grams

- $\mathrm{W} 3=$ dry weight of sample, crucible and cover in grams

Total Ash (Ash), expressed as a ratio (w/w) of ash to dry weight

$$
\% A S H=\frac{W 4-W 1}{W 3-W 1} \times 100
$$

- Where $\mathrm{W} 1$ = tare weight of crucible and cover in grams

- $\mathrm{W} 3=$ dry weight of sample, crucible and cover in grams

- $\mathrm{W} 4=$ weight of ash, crucible and cover in grams 


\section{Quality Control:}

\section{Comments:}

All samples should be analyzed in duplicate.

An acceptable average standard deviation among replicated analyses for moisture or dry matter is about \pm 0.10 , which results in a warning limit (2s) of about \pm 0.20 and a control limit (3s) of about \pm 0.30 . Plot the results of the duplicate analyses on an Rcontrol chart and examine the chart for trends. Results outside the 95 percent confidence limits warn of possible problems with the analytical system. Results outside the 99 percent confidence limits indicate loss of control, and results of the run should be discarded. Two consecutive analyses falling on one side of the mean between the warning limits and the control limits also indicate loss of control.

- If ash is intended for acid-insoluble ash analysis, refer to Part I-II in "Sequential Determination of Laboratory Dry Matter, Total Ash, and Ash Insoluble in $2 \mathrm{M}$ Hydrochloric Acid" 


\section{Appendix E: Example Fiber Analysis Datasheet}

\section{NDF/ADF/ADL - Cal Poly Beef Nutrition}

Study Number:

* Samples with a CV greater than 5 must be re-run

Date:

Analyst:

\begin{tabular}{|c|c|c|c|c|c|c|}
\hline Sample & & Bag & Sample & Final Bag & Final Bag & Final Bag \\
\hline ID \& Description & Bag \# & Weight & Weight & Weight, post-NDF & Weight, post-ADF & Weight, post-ADL \\
\hline & & & & & & \\
\hline \\
\hline
\end{tabular}

A

\begin{tabular}{|l|l|l|l|l|}
\hline & A & B & & \\
\hline & & & & \\
\hline
\end{tabular}




\section{Appendix F: Dry Matter, Organic Matter Datasheet}

\section{DM and OM - Cal Poly Beef Nutrition}

\section{Study Number:}

Date:

Analyst:

* Samples with a CV greater than 5 must be re-run

$100^{\circ} \mathrm{C}$

\begin{tabular}{|c|c|c|c|c|c|}
\hline Sample & & Cruc & Wet Sample & Dry Weight of & Post-Ash \\
\hline ID \& Description & Cruc ID & Weight $(\mathrm{g})$ & Weight (g) & Spl + Cruc (g) & Spl + Cruc wt (g) \\
\hline & & & & & \\
\hline & & & & & \\
\hline & & & & & \\
\hline & & & & & \\
\hline & & & & & \\
\hline & & & & & \\
\hline & & & & & \\
\hline & & & & & \\
\hline & & & & & \\
\hline & & & & & \\
\hline & & & & & \\
\hline & & & & & \\
\hline & & & & & \\
\hline & & & & & \\
\hline & & & & & \\
\hline & & & & & \\
\hline
\end{tabular}

B

\begin{tabular}{|l|l|l|l|}
\hline & & \\
\hline & \\
\hline
\end{tabular}




\section{Appendix G: Nitrogen Data Example Sheet}

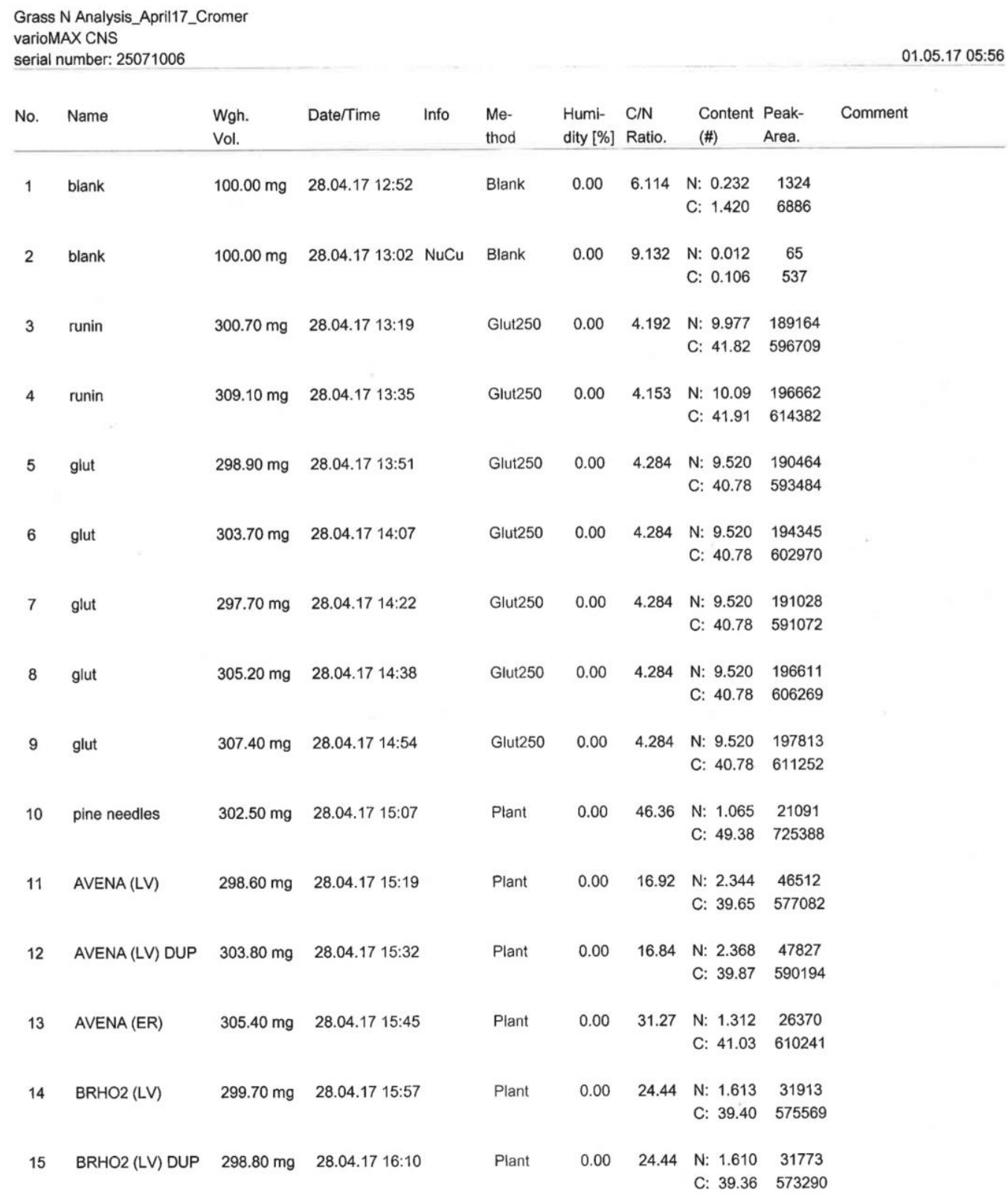

Caption (\#): [\%] if weight-in quantity in [mg], [mg/L] if volume in [mL]

Document: Grass N Analysis_April17_Cromer (varioMAX), Name: eassuperuser, Access: varioMAX superuser

Elementar Analysensysteme $\mathrm{GmbH}$

VarioMAX V7.3.7 05. Mar. 12, CN/Prec.-Mode, NC=s, S. No.: 25071006 Pane $1 / 3$

* Samples 1-10 were used for calibration and a standard of comparison for the grasses. 


\section{Appendix H: California Plant Species Report}

\section{Avena barbata, Avena fatua}

\section{Wild Oats}
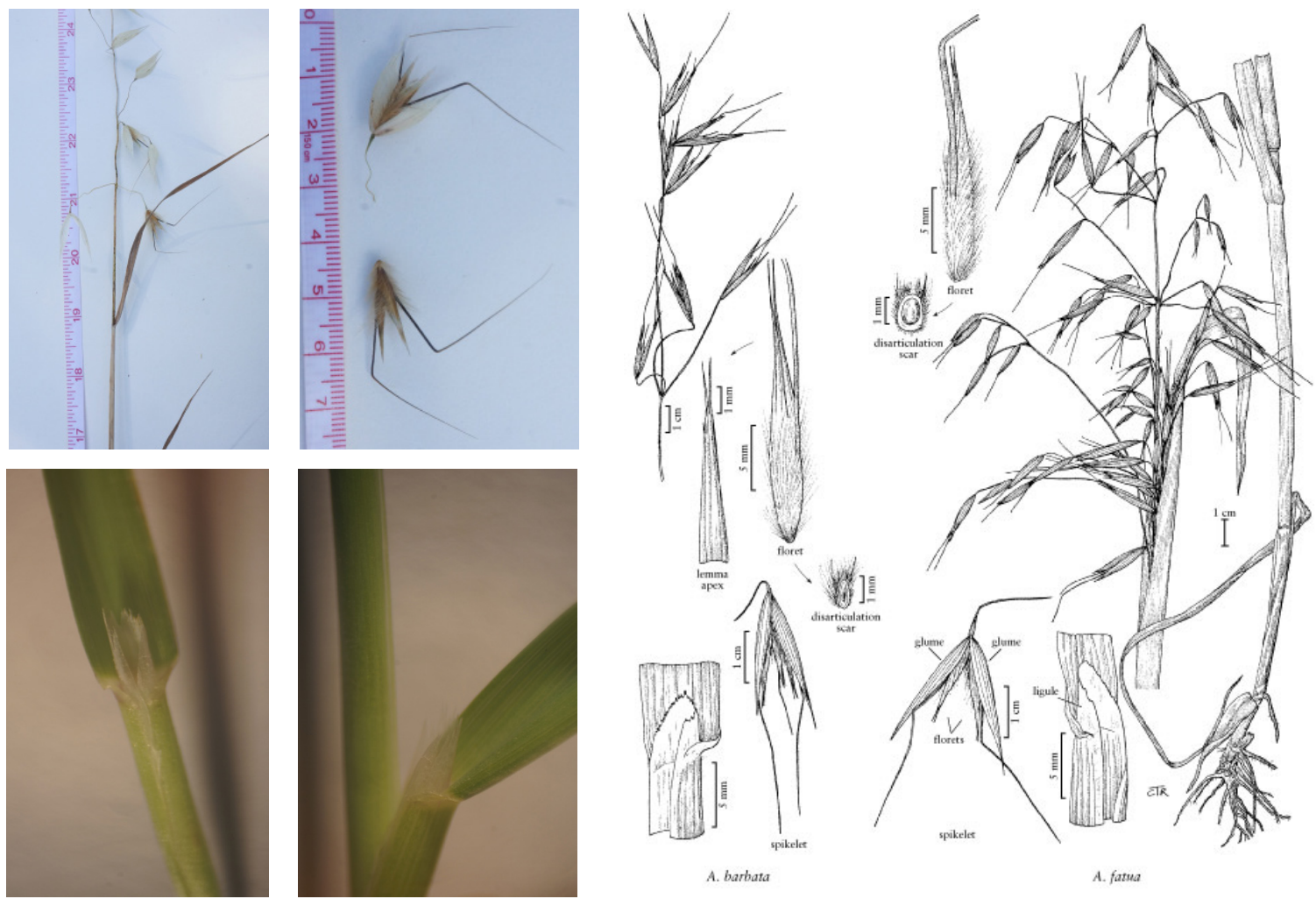

A. barbata

A. fatua

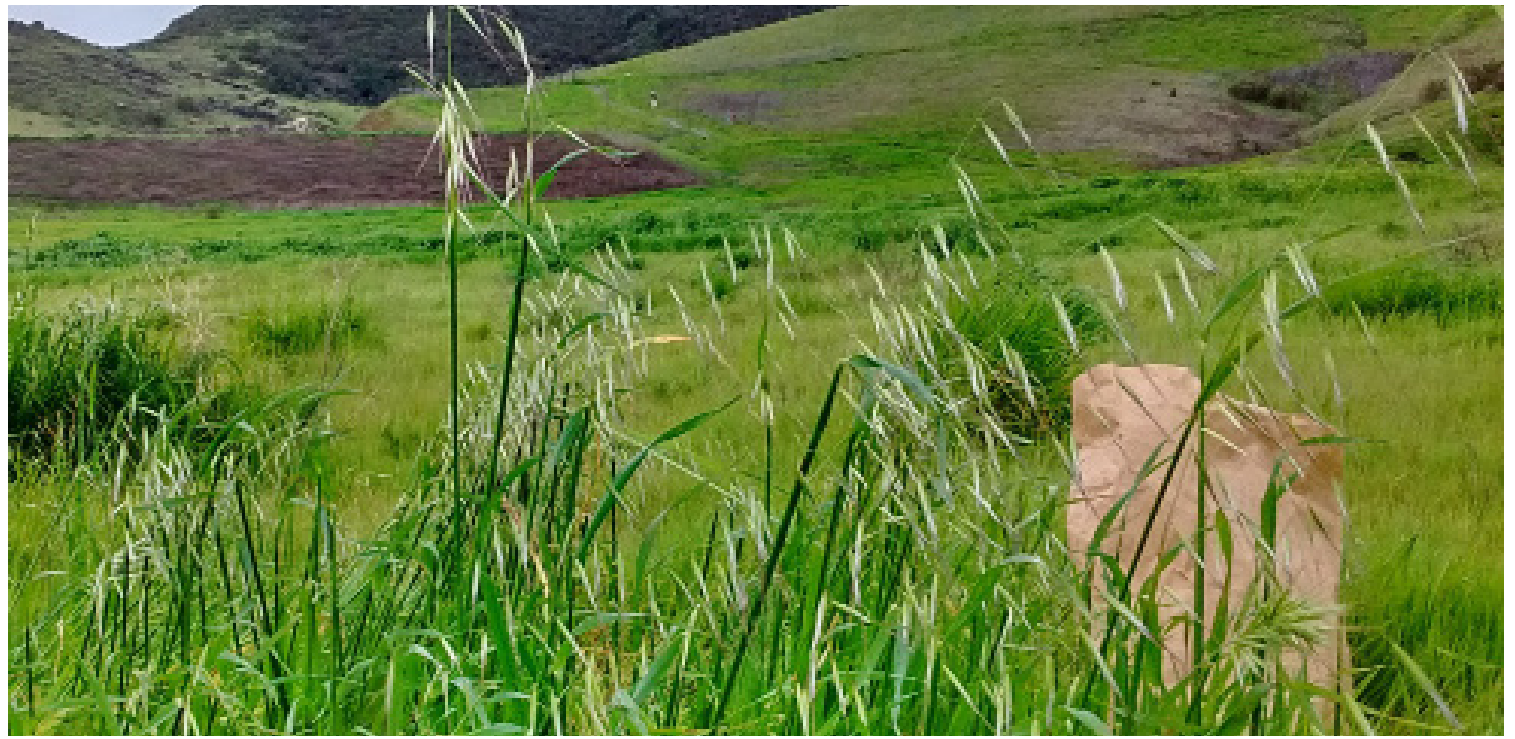

The Avena genus is the most prevalent and abundant weed in the world (Thurston, 1982) because of its rapid growth rate (UC ANR, 2017). The plant feature that most clearly distinguishes $A$. barbata from $A$. fatua are: the differences in the lemma length and whether or not the barbs separate. A. Fatua has an acute lobe, whereas, the barbs in A. barbata 


\section{Brachypodium distachyon \\ Purple False Brome}
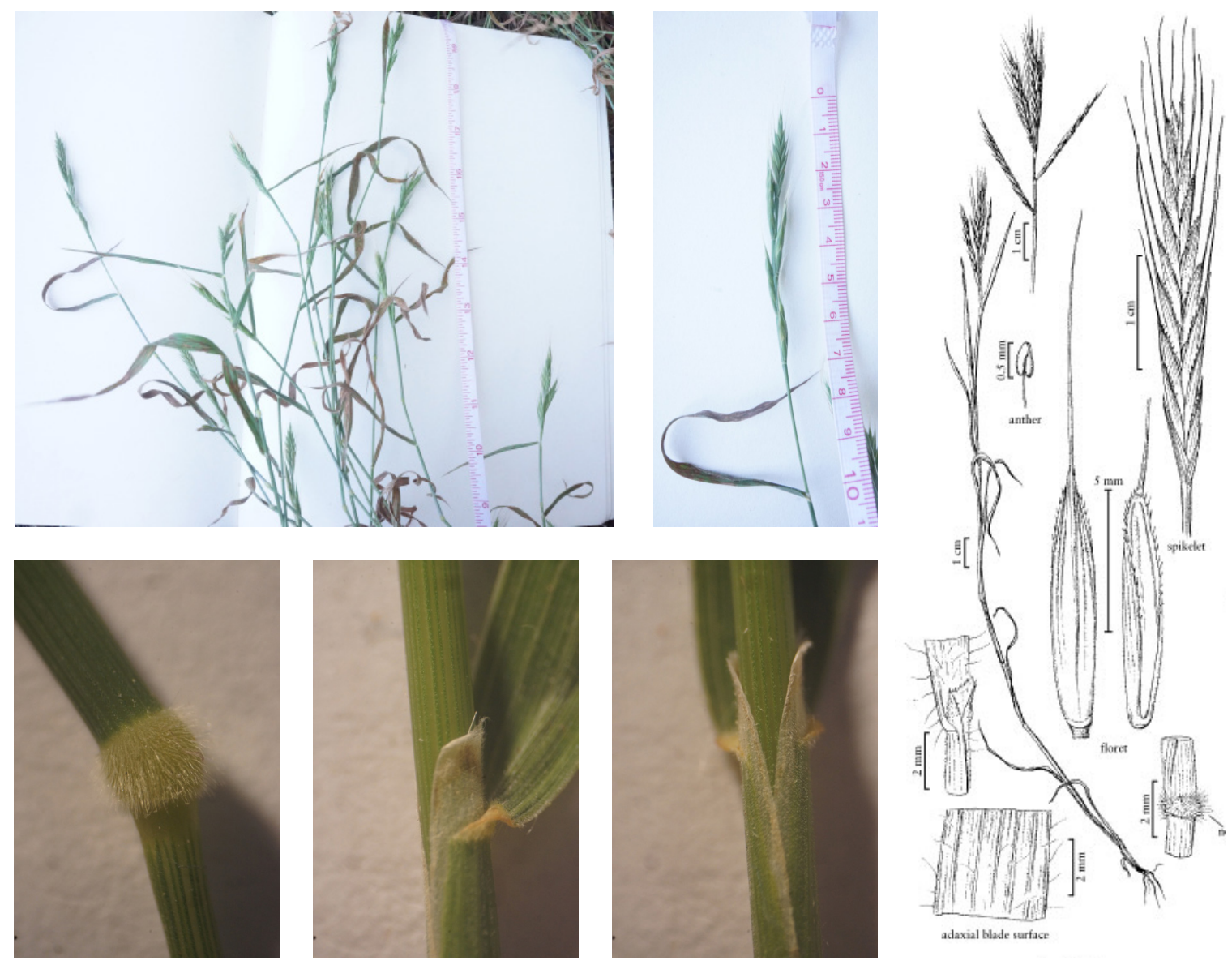

adaxial blade surface

Brachypodium distachyon originated from dry, open habitats in southern Europe. The appearance is a glaucous or bluish-green. The sheaths are open and overlapping. The nodes are completely covered in long trichomes, while the stem is smooth and striated, and only sparsely covered in shorter trichomes. Spikelets form a raceme pattern. Racemes are typically $2-7 \mathrm{~cm}$ in length with 1-7 overlapping, appressed spikelets. The spikelets are generally $15-40 \mathrm{~mm}$ and laterally compressed. Lemmas are usually 7-10 $\mathrm{mm}$ with 8-10 mm awns (Barkworth, et al., 2007). 


\section{Bromus hordeaceous}

\section{Soft Chess}
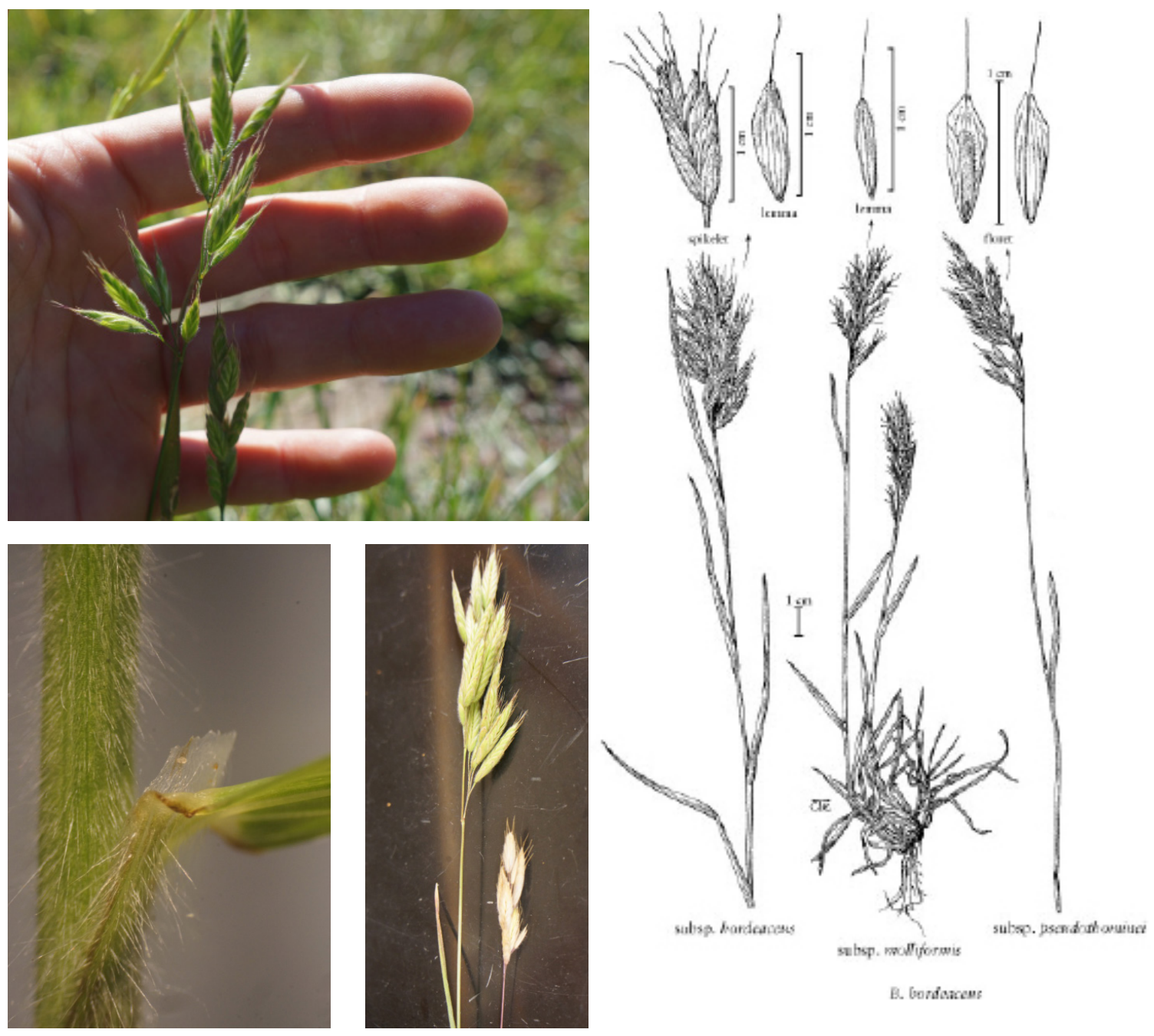

The feature that sets the Bromus genus apart from the rest of the wheatgrasses are the non-overlapping sheaths. They are most commonly seen either completely fused together at the collar, or fused partway down by a couple centimeters, as demonstrated by Bromus hordeaceous. B. hordeaceous is favorable to livestock, as it is considered to be the most nutritious and palatable of all California Bromus species. Fire has little to no effect on $B$. hordeaceous but has the potential to increase in abundance postfire (Howard, 1998). 
Elymus glaucus Blue Wildrye
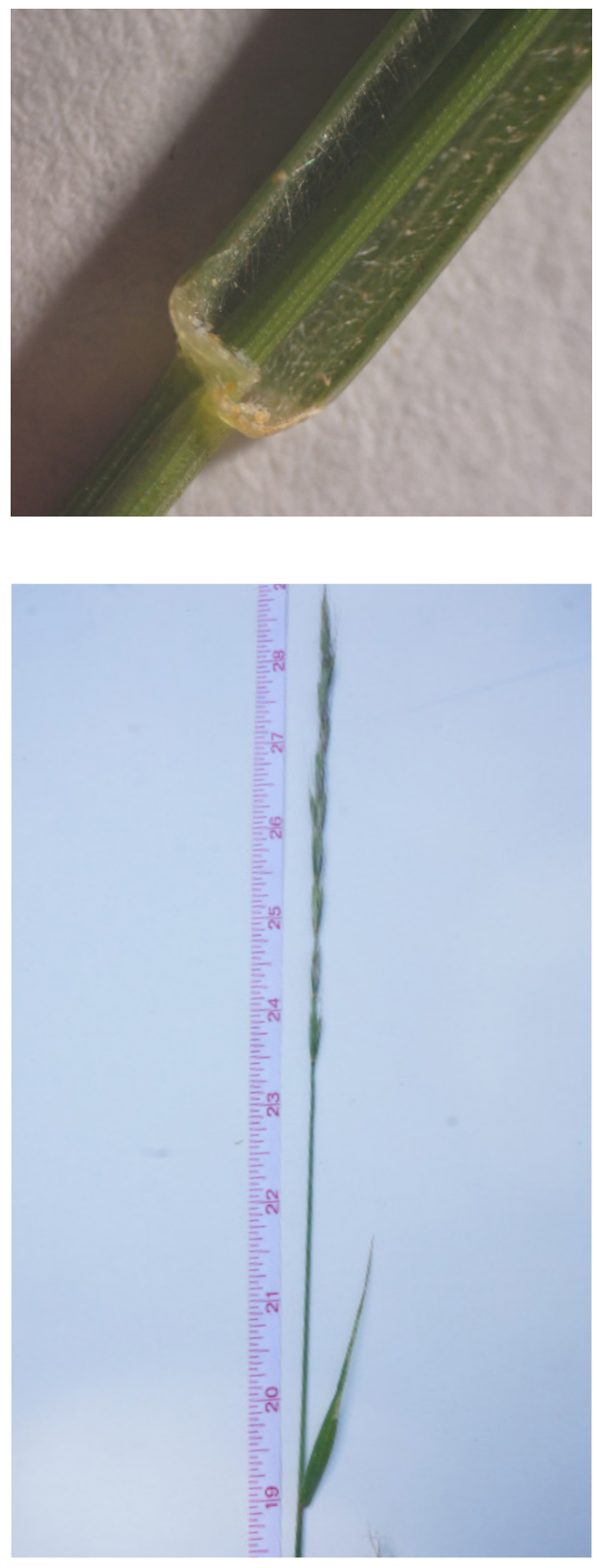
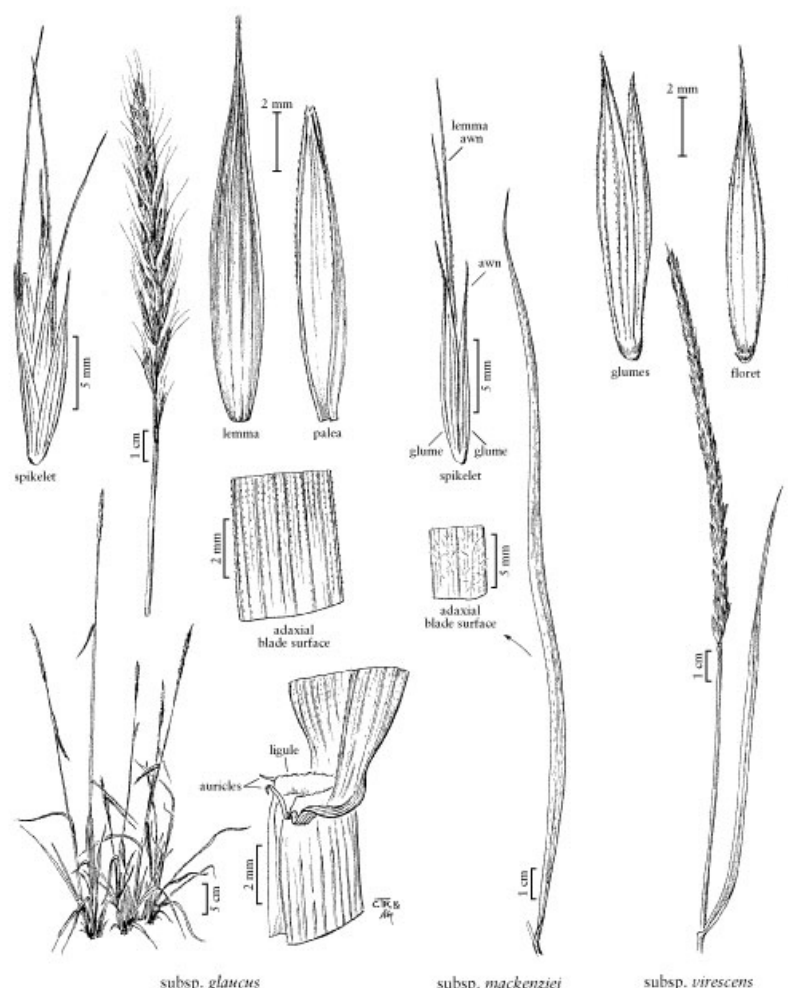

EIYMUS GLAUCUS
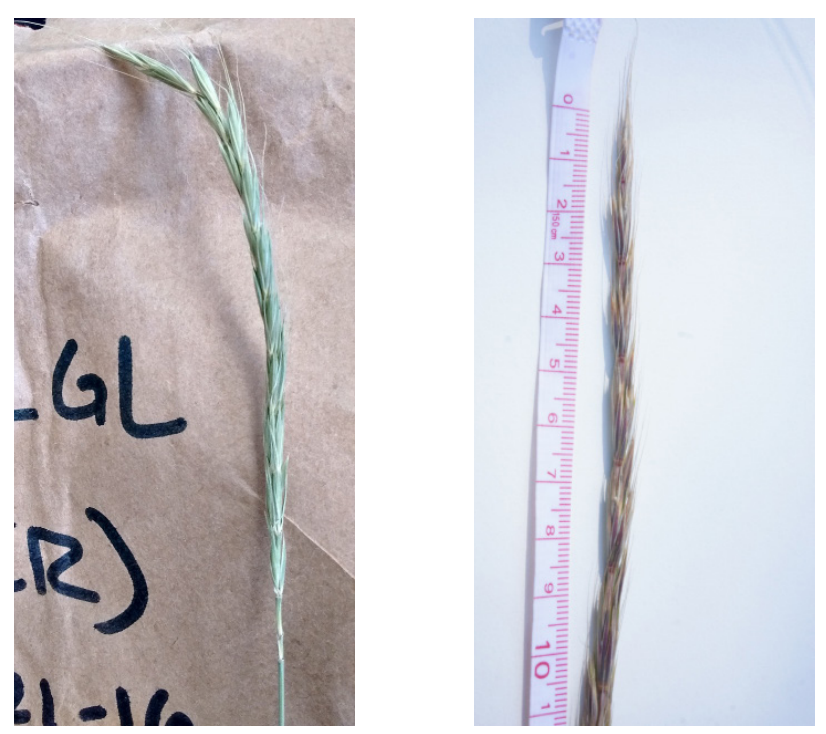

Elymus glaucus displays an overlapping sheath. No ligule is present, but somewhat of an auricle can be detected. On the inflorescence, there are several spikelets per node and on each spikelet the glumes are side by side, rather than overlapping. E. Glaucus is considered a decreaser, as it thrives in environments disturbed by fire (USDA Forest Service, 2017). 


\section{Erodium botrys \\ Broadleaf Filaree}
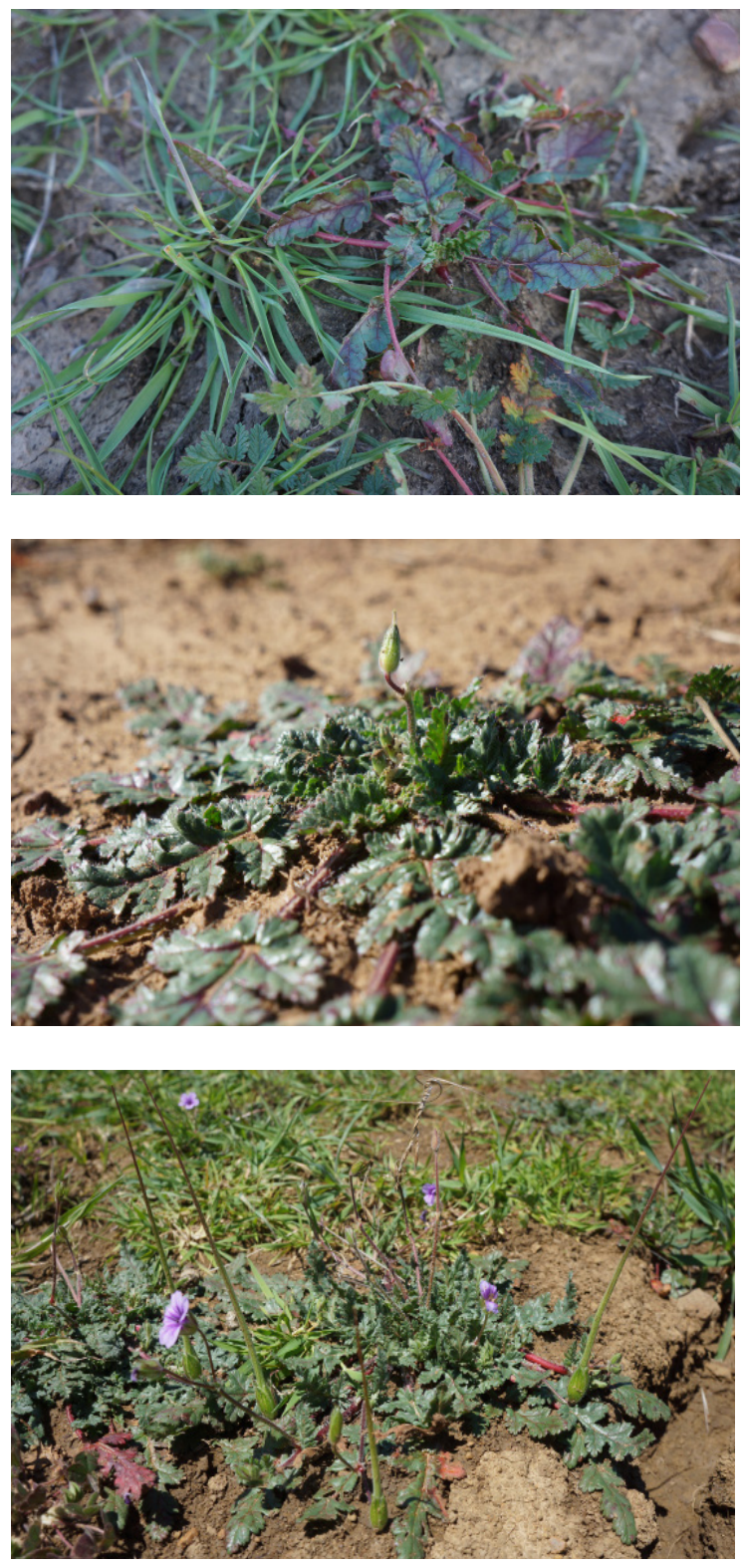
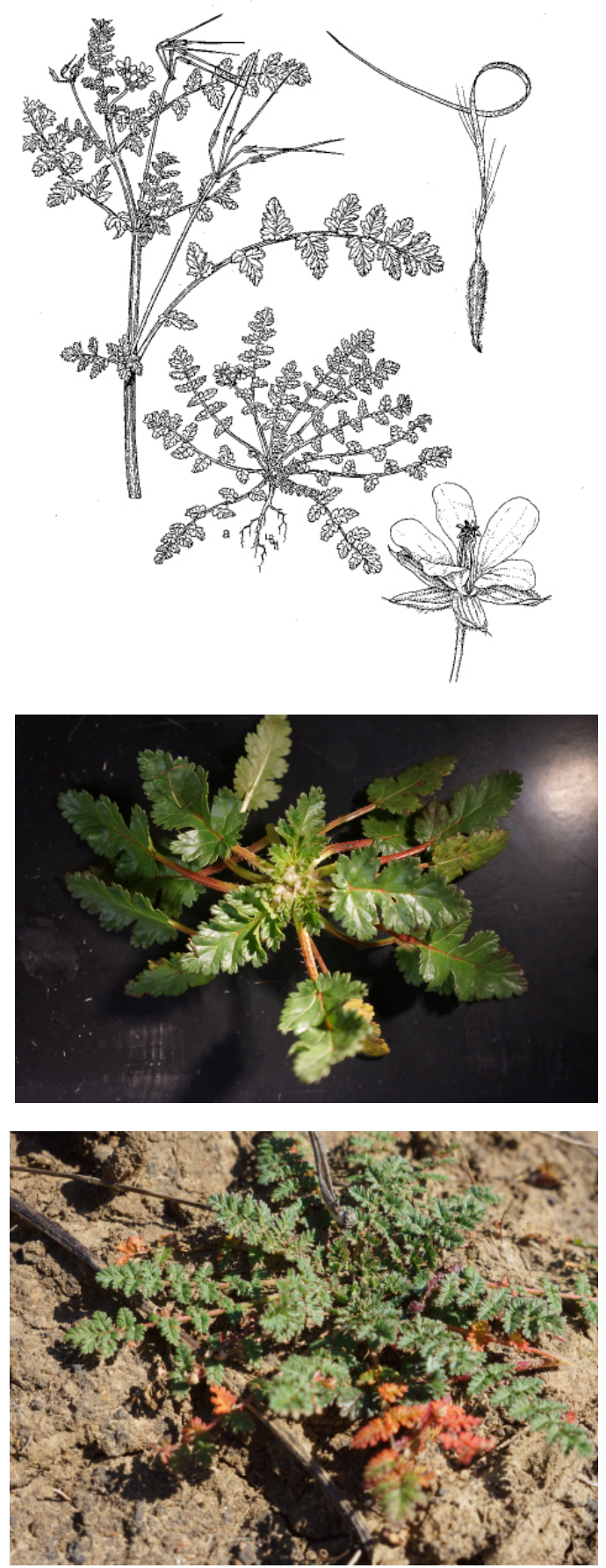

Erodium botrys, as well as the many other Erodium spp., comes into late vegetative stage quite early, around early February, and is in full bloom by mid-to late March. The primary difference between redstem (E. cicutarium) and broadleaf filaree (E. botrys) is how lobed their leaves are. The E. botrys has a single-lobed compound leaf, whereas many other erodium spp. have leaves that separate into many lobes (UC ANR, 2016). E. Cicutarium populations benefit from a fire; seed establishment increases as fire destroys the mulch layer (Howard, 1992). 


\section{Leymus tritichoides Creeping Wildrye}
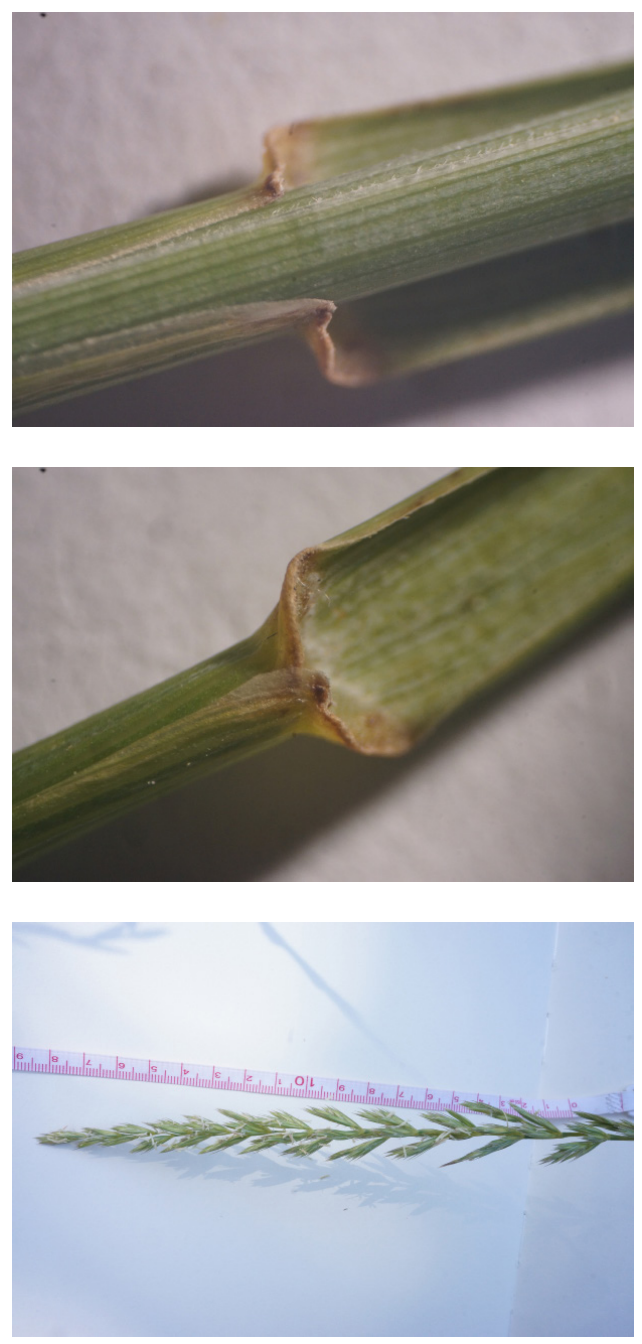

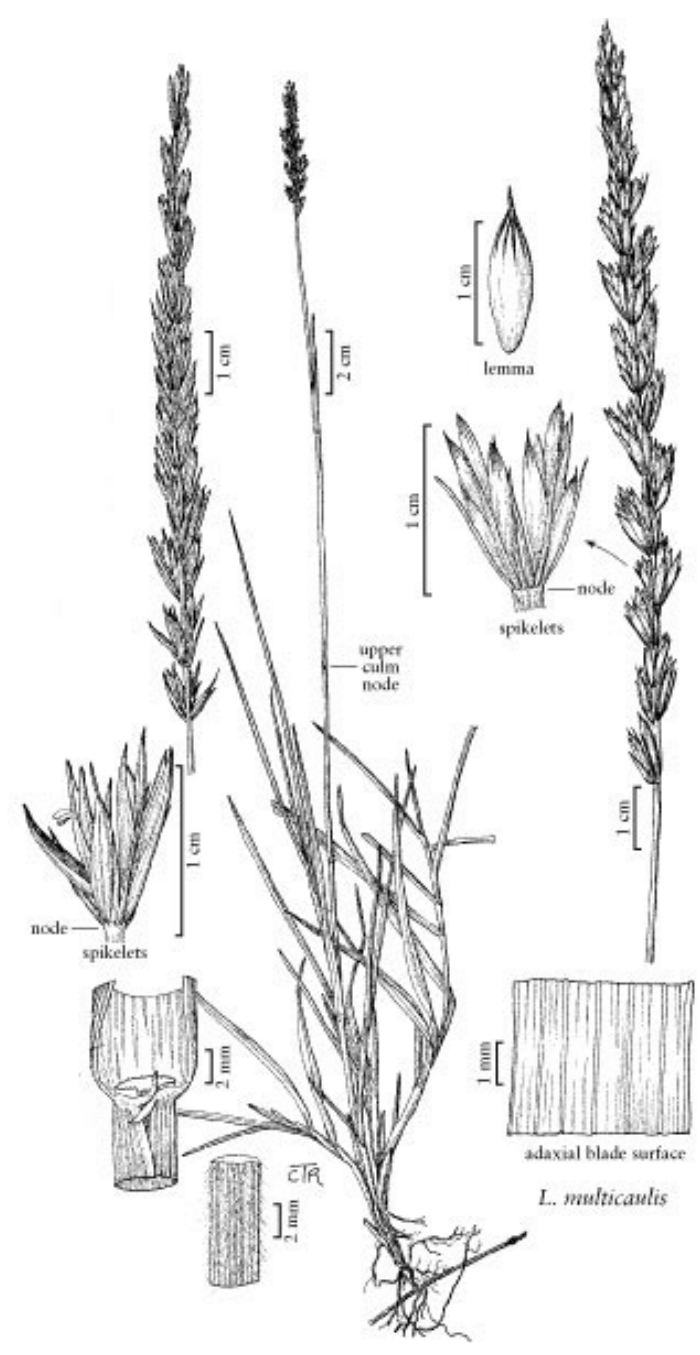

The leaves and stem of Leymus tritichoides (or Elymus tritichoides) have a coarser texture in comparison to Elymus glaucus, one might call the texture "scabrous". Similarly to E. Glaucus, L. triticoides has an overlapping sheath. The spikelets are clearly arranged on the inflorescence in a distichous manner. Within a single plant, there can be variation among the leaves. The lower leaves commonly have auricles, while the upper leaves do not. The leaves have a waxy surface and are rigid when dry. L. triticoides are not palatable to livestock grazing in the late summer, despite the fact that they may be the only green plant standing at that time. This species can be green or have a bluish tint to it. 


\section{Lolium multiflorum \\ Italian Ryegrass}
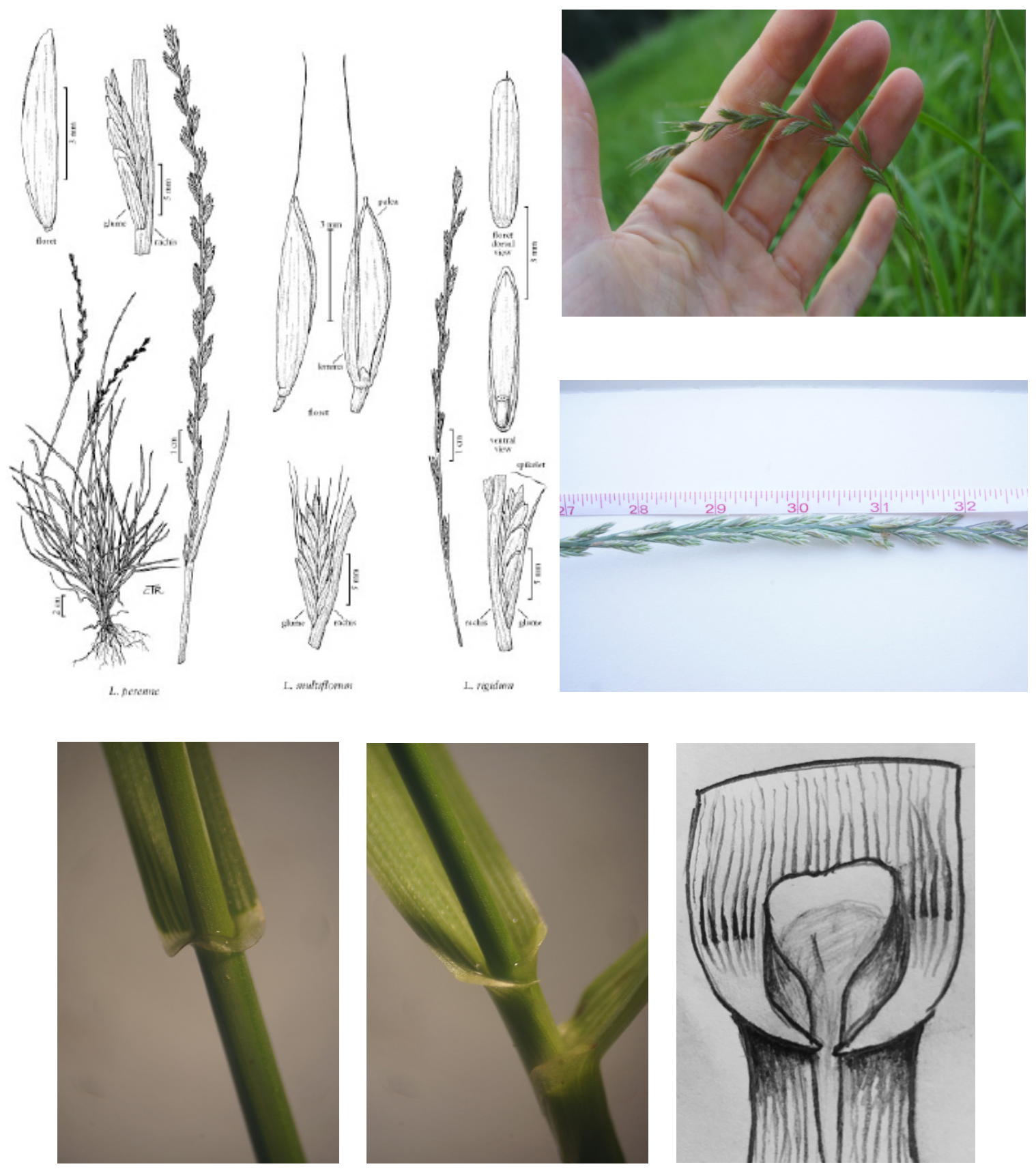

Lolium multiflorum has open sheaths that may sometimes be closed towards the bottom, below the collar. The Lolium genus has an edgewise arrangement of 7-11 veins running along the tiller leading up to each individual spikelet. L. multiflorum contains a red-tinged base. L. multiflorum is more related to the fescues than the wheatgrasses. The distinguishing feature L. multiflorum is the presence of auricles at the collar region. L. multiflorum seeds generally don't survive a fire, but they thrive after a fire; infact, $L$. Multiflorum is commonly planted after a prescribed fire for that reason (Carey, 1995). 


\section{Melica Californica, Melica Imperfecta, Melica Torreyana}

California Melic, Little California Melic, Torrey's melicgrass
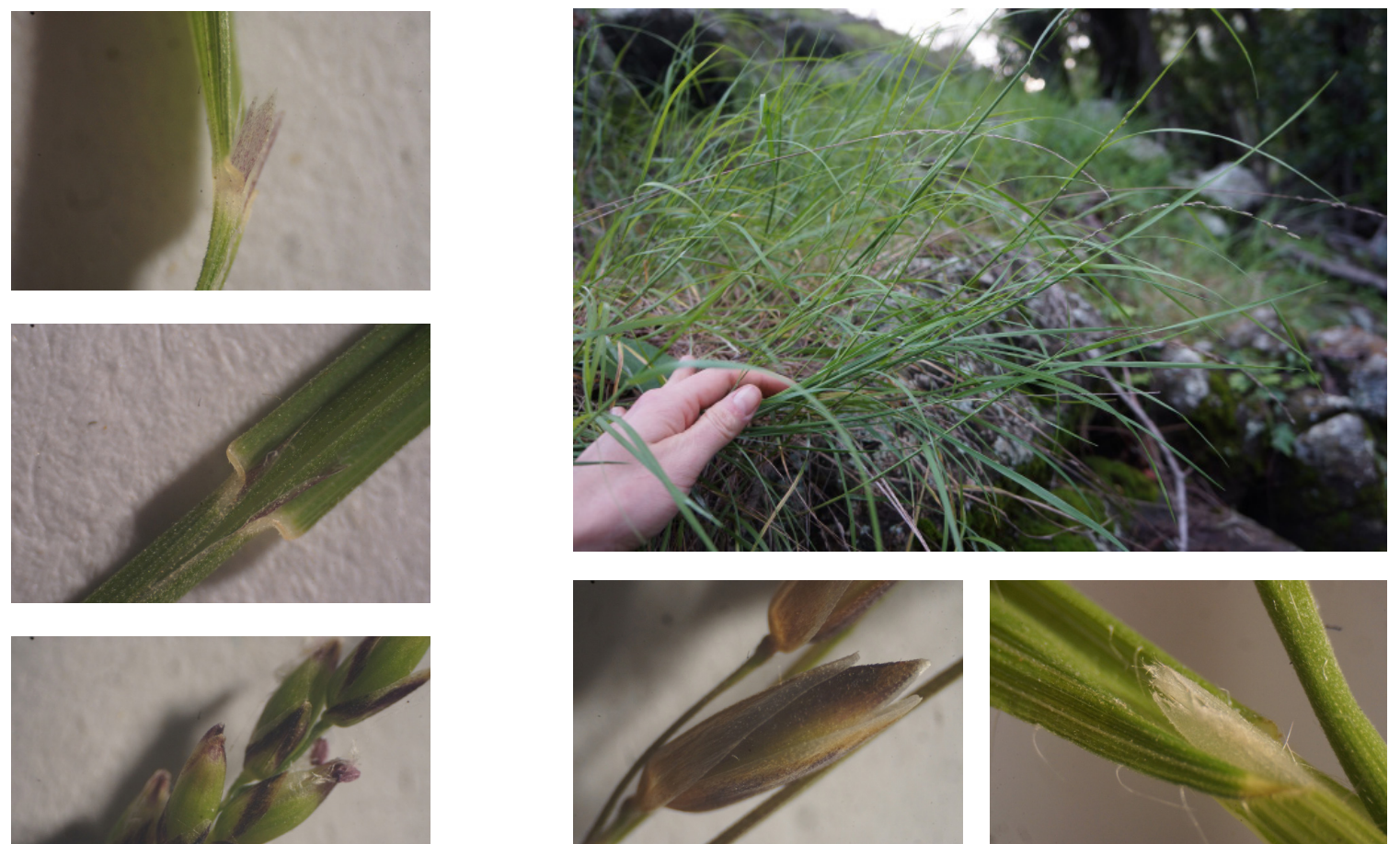

M. Torreyana
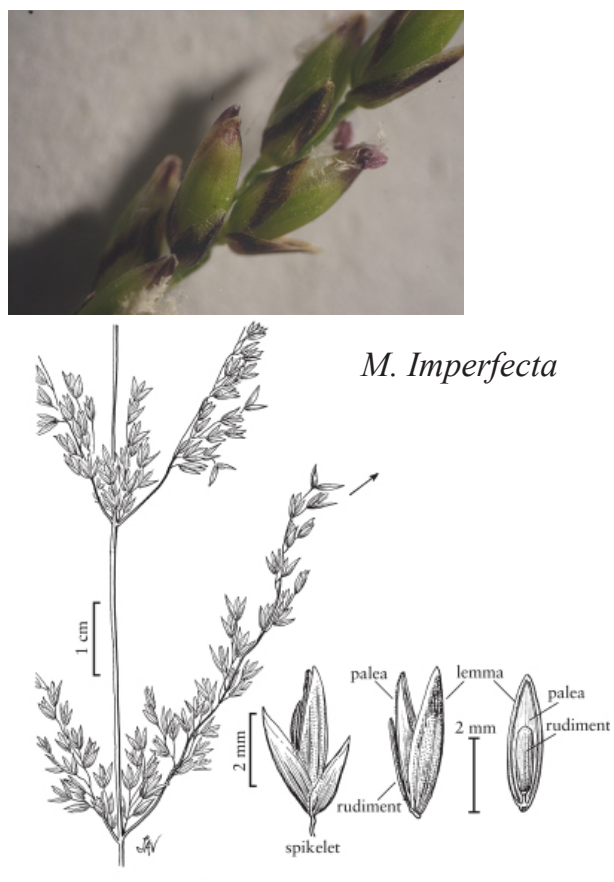

There are several species of Melica found on the Cal Poly, especially in the native prairie. The largest of these species is the Melica californica. M. californica has the largest anthers and spikelets of all the Melica species; the spikelets are about $1 \mathrm{~cm}$ in length. M. californica leaves have a papery look about them. The second largest Melica species found in the native prairie is the Melica torreyana where it is commonly found on rocky hillsides. It grows rather prolific and tall with spikelets reaching sizes 7-9 $\mathrm{mm}$ in length. Both the $M$. californica and $M$. torreyana have a rudimentary floret that is proportionally smaller for the size of the plant, in comparison to the stalk size. The Melica imperfecta, on the other hand, has a relatively large rudimentary floret and shorter stalk, in comparison to its overall size. The smallest of the species in the native prairie is $M$. imperfecta. It's spikelets are no larger than $3 \mathrm{~mm}$ in length with $1 / 2 \mathrm{~mm}$ anthers. Lastly, it has short, acute ligules. 


\section{Nassella lepida \\ Foothill Needlegrass}
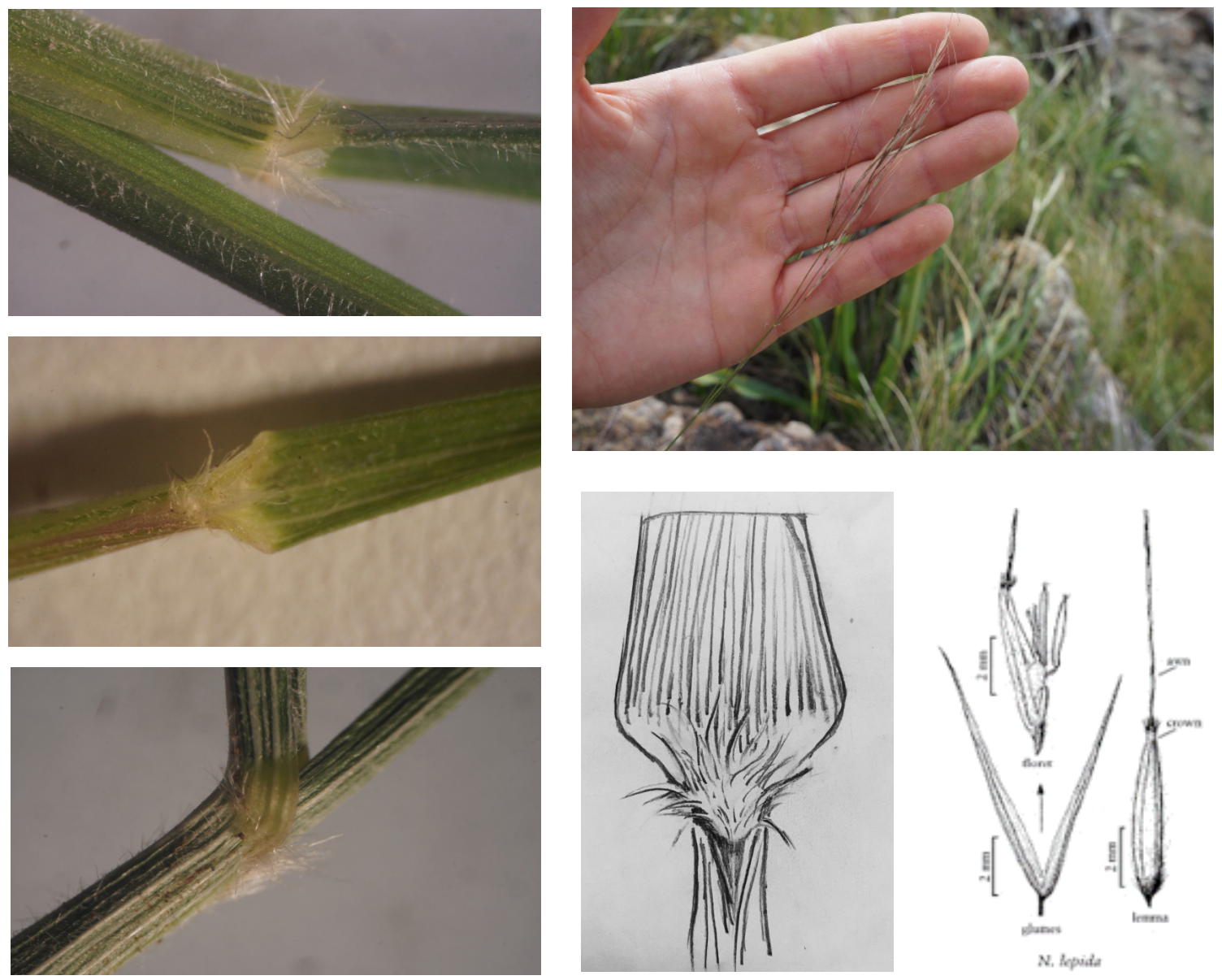

Nassella lepida has fine awns, in fact, it has the thinnest and smallest awns of all the Nassella species. The awns and spikelets are much shorter in length compared to those of Nasella pulchra. Th ${ }^{121}$ lus is quite sharp, and for this reason, livestock tend not to mess with the plant after it goes to flower, the early reproductive stage and beyond. When identifying this species, look for trichomes that line the collar all the way around and along the edges of the leaves. Additionally, the leaves have an open sheath. 


\section{Nassella pulchra \\ Purple Needlegrass}
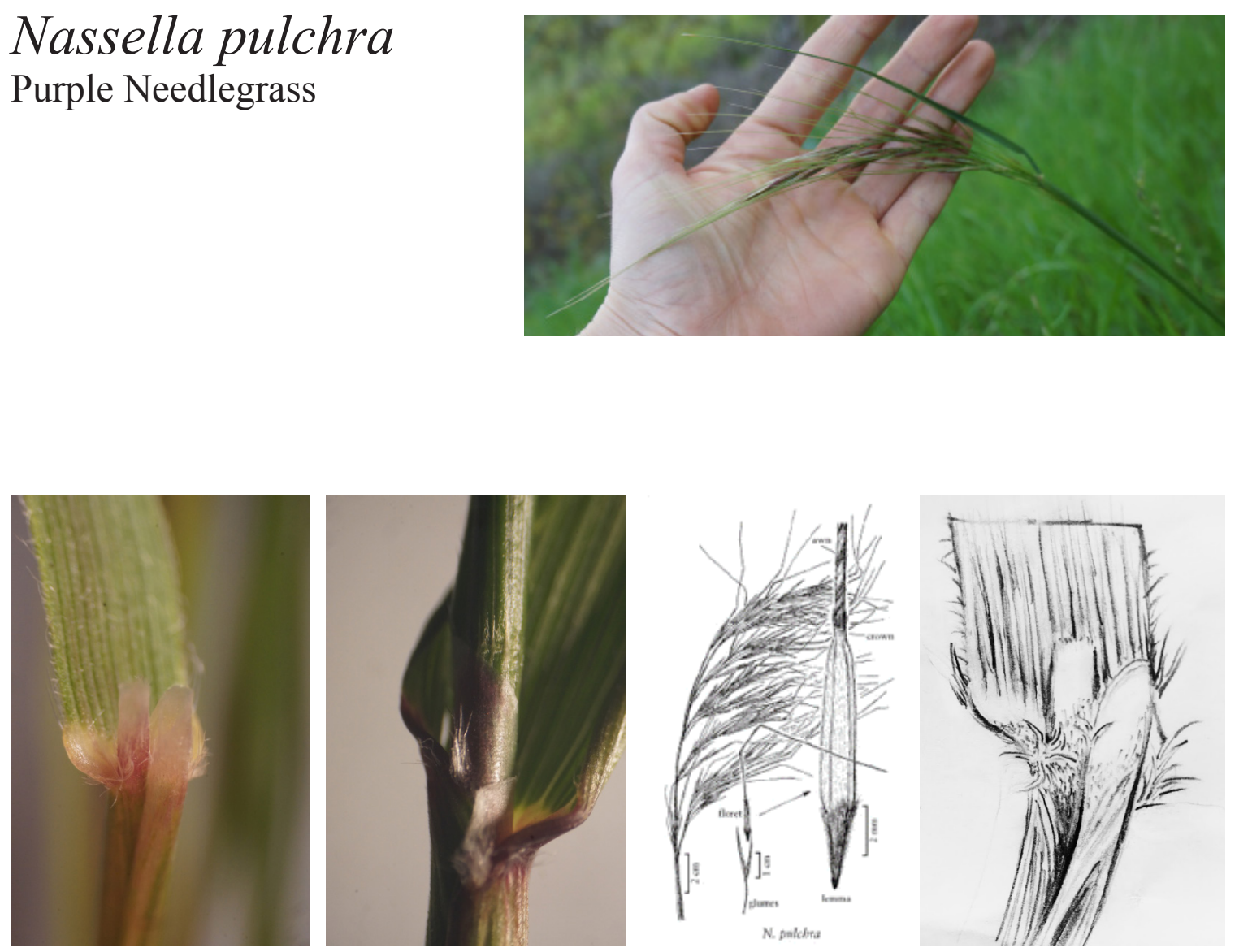

Nassella pulchra has a great amount of variation in the color and shape of its ligules and articles. The most common colors found on individuals in the native prairie can range from a light pink to a deep purple. The production of water-soluble pigments are a result of exposure to UV light, various plant lineages, soil chemistry, temperature, etc. Unlike $N$. lepida, the lemmas are hairy between veins from seedling to maturity. The distinguishing feature that one should use when identifying $N$. pulchra are the presence of an open sheath and the lack of an auricle. The ligules are rather pronounced and membranous. Additionally, the ligules are for the most part smooth and hairless, however, there are a tuft of hairs at the collar. In comparison to $N$. lepida, $N$. pulchra is a much leafier plant and has a lemma length of $2 \mathrm{~mm}$ or greater. Fire has mixed effects on N. Pulchra, in which, varies from site to site throughout California; however, coastal populations are generally unaffected by fall burning. In fact, fall burning along with moderate spring grazing benefits $N$. pulchra because it increases seedling establishment (Montalvo et al., 2010). 


\section{References}

Barkworth, M.E., Capels, K.M., Long, S., Anderton, L.K., Piep, M.B., 2007. Brachypodi um, in: Barkworth et al. (Ed.), Flora of North America Vol. 24.

Carey, H., J., 1995. Lolium multiflorum, in: USDA Forest Service (Ed.), Fire Effects Infor mation System, (Online). Rocky Mountain Research Station, Fire Sciences Labora tory.

Howard, J.L., 1998. Bromus hordeaceous, in: USDA Forest Service (Ed.), Fire Effects In formation System, (Online). Rocky Mountain Research Station, Fire Sciences Lab oratory.

Howard, J.L., 1992. Erodium cicutarium, in: USDA Forest Service (Ed.), Fire Effects Infor mation System, (Online). Rocky Mountain Research Station, Fire Sciences Labora tory.

Montalvo, A.M., Goode, L., Beyers, J.L., 2010. Plant Profile for Nassella pulchra. Native Plant Recommendations for Southern California Ecoregions.

Resources, U. of C.D. of A. and N., 2017. Oat. http://ucanr.edu/sites/asi/db/cover crops.cfm?crop_id=28 (accessed 5.28.17).

Thurston, J.M., 1982. Wild oats as successful weeds. https://link.springer.com/chapte r/10.1007\%2F978-94-017-0916-3_18 (accessed 5.27.17).

University of California Division of Agriculture and Natural Resources, 2016. Filarees (Erodium spp.). URL http://ipm.ucanr.edu/PMG/WEEDS/filarees.html (accessed 5.19.17).

USDA Forest Service, 2017. Elymus glaucus. https:// www.fs.usda.gov/detailfull/umatilla/learning/nature-science/?cid=stelprd b5251262\&width=full (accessed 5.17.17). 